UNIVERSIDADE DE BRASÍLIA

FACULDADE DE DIREITO

PROGRAMA DE PÓS-GRADUAÇÃO EM DIREITO

IGOR CHAGAS DE CARVALHO

DIREITO AO ESQUECIMENTO: REAÇÃO À EXPANSÃO SISTÊMICA DOS MEIOS DE COMUNICAÇÃO DE MASSA?

Brasília - DF

2016 


\title{
DIREITO AO ESQUECIMENTO: REAÇÃO À EXPANSÃO SISTÊMICA DOS MEIOS DE COMUNICAÇÃO DE MASSA?
}

\author{
Dissertação apresentada ao Programa de Pós-Graduação \\ em Direito da Faculdade de Direito da Universidade de \\ Brasília como requisito parcial para obtenção do grau de \\ Mestre em Direito.
}

Orientador: Prof. Dr. Marcelo da Costa Pinto Neves.

Brasília - DF 
Ficha catalográfica elaborada automaticamente, com os dados fornecidos pelo(a) autor(a) Direito ao esquecimento: reação à expansão sistêmica dos meios de comunicação de massa? / Igor Chagas de Carvalho; orientador Marcelo da Costa Pinto Neves. -- Brasilia, 2016.

$142 \mathrm{p}$.

Dissertação (Mestrado - Mestrado em Direito) -Universidade de Brasília, 2016.

1. Direito ao esquecimento. 2. Sistema dos meios de comunicação de massa. 3. Direitos fundamentais ou humanos. I. Neves, Marcelo da Costa Pinto, orient. II. Título. 


\section{DIREITO AO ESQUECIMENTO: REAÇÃO À EXPANSÃO SISTÊMICA DOS MEIOS DE COMUNICAÇÃO DE MASSA?}

Após sessão pública de defesa desta dissertação de mestrado, realizada em Brasília/DF, no dia 30 de março de 2016, o candidato foi considerado pela banca examinadora.

Prof. Dr. Marcelo da Costa Pinto Neves - Orientador - FD/UnB

Prof. Dr. Hélio Sílvio Ourém Campos - UNICAP

Prof. Dr. Pablo Holmes Chaves - IPOL/UnB 
Para a Vanila e o Topinho, porque sem eles eu não teria o maior título de todos:

pai. 


\section{AGRADECIMENTOS}

A realização de um trabalho dissertativo como o que ora se apresenta não seria possível sem a ajuda, o apoio e a contribuição de inúmeras pessoas.

Inicialmente, gostaria de agradecer ao professor Marcelo Neves pela pronta disposição em aceitar ser meu orientador de pesquisa, pela sempre cordial disponibilidade e pelas atenciosas observações feitas.

Aos professores Menelick de Carvalho Netto e Cristiano Paixão, pelos ensinamentos em sala de aula, fundamentais para a concretização dos primeiros passos dessa jornada.

Na pessoa da Euzilene Morais (“Zizi”), gostaria de registrar meu agradecimento ao competente e atencioso trabalho desempenhado pela equipe da Secretaria da PósGraduação da Faculdade de Direito da UnB.

Ao Raphael Peixoto de Paula Marques, colega de Advocacia-Geral da União e de mestrado, pela constante troca de ideias, pelas conversas e discussões envolvendo a temática a ser pesquisada, pelo inestimável espaço aberto à concretização das atividades de monitoria, enfim, pela ajuda e orientação nos diversos trilhos percorridos.

Aos colegas da Procuradoria-Geral Federal/AGU, sobretudo ao Diretor do Departamento de Consultoria, Antonio Carlos Soares Martins, pelo fundamental apoio e incentivo ao longo de todo o curso, em especial no período de escrita da dissertação.

Ao Bruce, Steve, Adrian, Janick, Dave e Nicko, por fazerem músicas de excelência, essenciais para o transcurso e para as pausas ao longo de todo o caminho.

Ao meu irmão, Iuri Carvalho, pelas conversas, pelo diálogo, pelo incentivo, pela torcida e também pelas observações diretas e certeiras, sempre fundamentais para os passos seguintes.

Aos meus pais, Antônio Carlos e Maria Goretti, os grandes doutores e orientadores da minha vida, pela compreensão, pelo apoio, pela torcida, pela força e pela fé. Por tudo. 
À minha esposa Vanila e ao meu filho Igor (“Topinho”), pela presença, pela paciência, pelo constante incentivo e pela compreensão ao longo de toda esta caminhada. A conclusão desse ciclo não teria sido possível sem todo esse apoio logístico e afetivo.

O êxito não é meu, é nosso.

Parafraseando o poeta, sigamos de mãos dadas. 


\section{RESUMO}

Este trabalho analisa o chamado "direito ao esquecimento". Inicia-se com a descrição de casos paradigmáticos oriundos de diferentes jurisdições, com a apresentação de mudanças técnicas e sociais e com a exposição de novos significados acrescidos à ideia de privacidade que se afiguram relevantes para a emergência e o delineamento de um amplo discurso de um direito ao esquecimento. Em seguida, são apresentadas as principais características do discurso do direito ao esquecimento, assim como também os principais riscos envolvidos na sua adoção, especialmente aqueles que dizem respeito à censura e à preservação da memória e da história. Jogam-se luzes sobre o modo pelo qual o sistema dos meios de comunicação de massa (incluindo novas mídias) atua e sobre como ele contribui para o contexto de emergência do direito ao esquecimento. Finalmente, a dissertação situa o direito ao esquecimento como um direito fundamental ou humano que emerge num contexto de reação às tendências expansionistas do sistema dos meios de comunicação de massa, assegurando às pessoas o direito de questionar o uso ou reuso de informações passadas e verdadeiras que lhes dizem respeito.

Palavras-chave: Direito ao esquecimento. Sistema dos meios de comunicação de massa. Direitos fundamentais ou humanos. 


\begin{abstract}
This work analyzes the so called "right to be forgotten". It begins with the description of leading cases from different jurisdictions, with the presentation of technical and social changes and with the exposition of new meanings added to the idea of privacy that are relevant to the rise and shape of a wide right to be forgotten discourse. The main features of the right to be forgotten discourse are then exposed, as well as the main risks involving its adoption, especially those related to censorship and the preservation of memory and history. Lights are shed upon the way the mass media system (including new media) works and upon the way it contributes to the context of emergence of the right to be forgotten. Finally, the dissertation places the right to be forgotten as a fundamental or human right that emerges in a context of reaction to the expansionist tendencies of the mass media system, securing to persons a right to question the uses or reuses of past and true informations that are related to them.
\end{abstract}

Key words: Right to be forgotten. Mass media system. Fundamental or human rights. 


\section{SUMÁRIO}

INTRODUÇÃO .............................................................................................................1

CAPÍTULO 1 - CASOS PARADIGMÁTICOS ...................................................................8

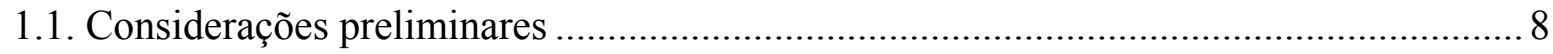

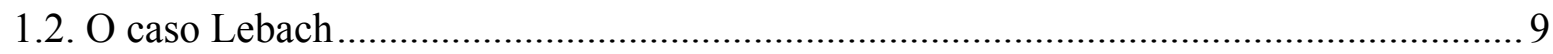

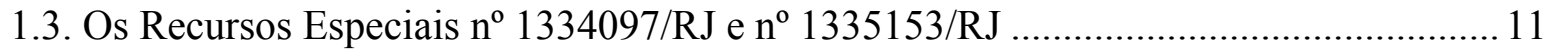

1.4. O caso Google vs. Mario Costeja González.............................................................. 20

1.5. O Recurso Especial $n^{0} 1316921 / R J$ (caso Xuxa), a Reclamação $n^{0}$ 5.072/AC, a Reclamação $n^{\circ}$ 18.685/ES e o caso Equustek Solutions Inc. vs. Google Inc.........................26

1.6. Sobre a repercussão e o cumprimento da decisão proferida no caso Google vs. Mario

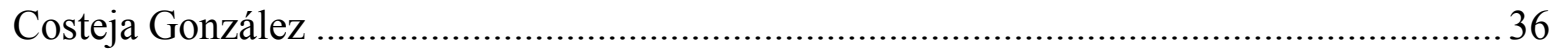

CAPÍTULO 2 - BALIZANDO O DIREITO AO ESQUECIMENTO ................................ 40

2.1. Por que um direito ao esquecimento? Sobre tecnologia, memória e privacidade ......... 40

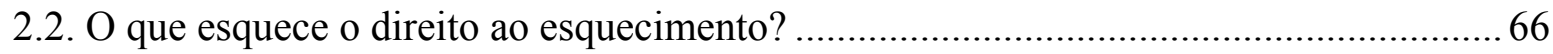

CAPÍTULO 3 - DIREITO AO ESQUECIMENTO COMO REAÇÃO AOS MEIOS DE

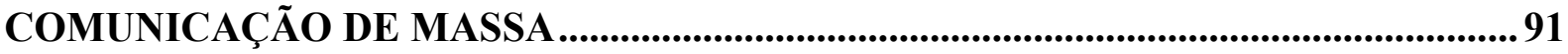

3.1. Sobre os meios de comunicação de massa e as novas mídias digitais...........................91

3.2. O direito ao esquecimento como limite à expansão dos meios de comunicação de

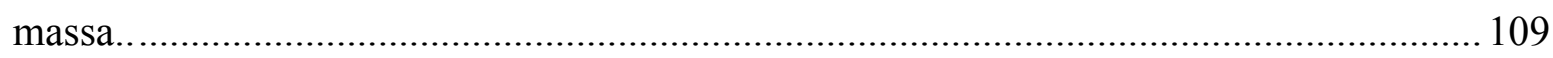

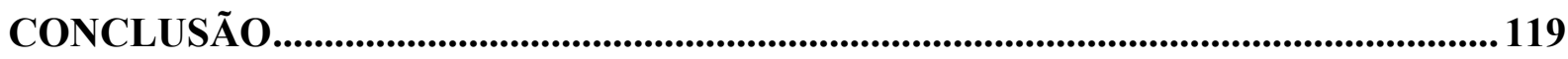

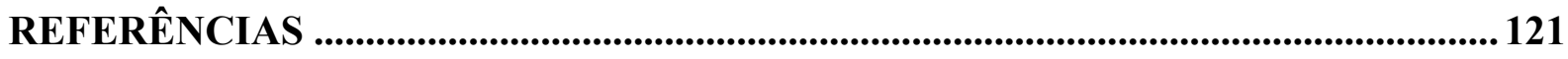

LISTA DE CASOS JUDICIAIS RELATADOS NO CAPÍTULO 1............................ 126

ANEXO - LEI No 12.965, DE 23 DE ABRIL DE 2014 (MARCO CIVIL DA

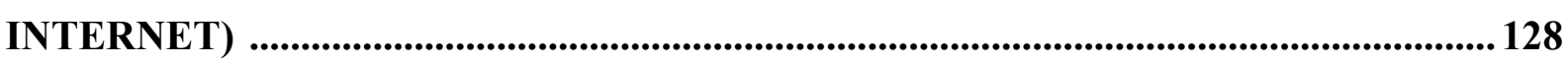




\section{INTRODUÇÃO}

Imagine que você é um professor ou professora de uma escola e que, num carnaval ou evento festivo qualquer, excedeu-se na bebida, subiu num trio elétrico ou numa mesa de bar e dançou fervorosamente na "boquinha da garrafa". Alguém filmou a performance, que veio a "cair na internet" - no YouTube, por exemplo. Incontáveis pessoas viram o vídeo, incluindo os integrantes da direção da escola onde você trabalha - ou melhor, trabalhava, já que você terminou por ser demitido em virtude da conduta "reprovável" perante a posição que ocupava. Agora, mesmo passado muito tempo - a ponto de a música nem mais sucesso fazer -, você encontra-se desempregado e sem perspectivas de vislumbrar uma nova ocupação, eis que a (má-)fama o persegue: os potenciais empregadores sempre ficam sabendo de sua performance quando, no momento das análises cadastrais, pesquisam por você no Google, por exemplo.

A situação acima, embora imaginada, nada tem de ficcional. Ela generaliza e exemplifica casos concretos que estão a ocorrer não só no Brasil, mas no mundo todo: pessoas estão sendo "condenadas" a rememorar fatos incômodos de seu passado e a arcar com consequências deles decorrentes no presente de suas vidas, ainda que muitas vezes já tenham lidado com as eventuais sanções administrativas, cíveis ou mesmo penais decorrentes de suas condutas. Diz-se, a respeito, que a sociedade, em sua autodescrição atual, nada esquece e que, uma vez on-line, sempre on-line.

No Brasil, Burgos (2014) dá conta da situação em que uma professora baiana dançou, sob efeito de álcool, em cima do palco de um show de pagode. A música continha uma coreografia de rebolados e levantamentos de saia. Uma vez disponibilizado no YouTube, o vídeo permitiu a identificação da professora, que foi perseguida e demitida da escola onde trabalhava. Sem identificar de quem se trata, Burgos destaca que a professora não consegue emprego por conta do vídeo e que ainda hoje uma busca no Google com seu nome completo traz o vídeo em questão como primeiro resultado.

\footnotetext{
${ }^{1}$ A expressão refere-se à música "Na boquinha da garrafa", sucesso da banda É o Tchan.
} 
Há o caso de Stacy Snyder, então uma mãe solteira de 25 anos que queria ser professora nos Estados Unidos. Embora tivesse cumprido todas as obrigações do curso que fazia (integralizado os créditos, passado em todos os exames e completado os treinos práticos), ela foi informada por representantes da universidade de que não poderia se tornar uma docente, tendo inclusive negada a entrega de seu certificado, em virtude de seu comportamento ser inadequado para alguém que postulava tal colocação. O comportamento referido foi extraído de um registro diligentemente identificado por um professor da escola onde ela estava estagiando: a foto, postada pela própria Stacy Snyder na rede social MySpace, mostrava-a fantasiada, com um chapéu de pirata, bebendo num copo de plástico e continha a legenda "pirata bêbado". Tal conduta, segundo a universidade, não seria profissional, pois exporia os alunos ao registro de um professor bebendo álcool. Mayer-Schönberger (2009, p. 1) aponta que Stacy Snyder considerou a possibilidade de retirar a foto, mas que o dano já estava feito, afinal, sua página de internet já havia sido catalogada por motores de busca e sua foto, restava, assim, arquivada por rastreadores da internet (web crawlers).

Andrew Feldmar é, por sua vez, um psicoterapeuta canadense na casa dos setenta anos que vive em Vancouver. Em 2006, ele tentou cruzar a fronteira do Canadá com os Estados Unidos - como já o havia feito várias outras vezes - no intuito de buscar um amigo no aeroporto internacional de Seattle-Tacoma. Desta vez, contudo, um guarda da fronteira consultou pelo seu nome num motor de busca da internet e encontrou um artigo escrito por Feldmar para um periódico interdisciplinar em 2001, no bojo do qual ele mencionara ter usado LSD nos anos 1960. Em virtude disso, o psicoterapeuta foi detido por quatro horas, teve suas impressões digitais recolhidas e, após ter assinado uma declaração de que teria usado drogas quase quatro décadas atrás, foi barrado de entrar novamente nos Estados Unidos. Mayer-Schönberger destaca que Feldmar, um profissional estabelecido e sem registros criminais, sabe que violou a lei, mas sustenta que não fez uso de drogas ao longo dos mais de trinta anos antes de ser parado pelo guarda. Para ele, o uso do LSD seria uma ofensa já esquecida pela sociedade, algo irrelevante para a pessoa que ele tinha se tornado. "Mas, por conta da tecnologia digital, a habilidade da sociedade para esquecer restou suspensa e substituída pela memória perfeita” (MAYER-SCHÖNBERGER, 2009, p. 4, tradução nossa).

O que os casos acima brevemente relatados têm como pano de fundo em comum é $\mathrm{o}$ fato de as atuais tecnologias terem facilitado e barateado exponencialmente o fluxo, o registro e o armazenamento de informações sobre os mais variados aspectos da vida dos 
indivíduos, permitindo o fácil resgate por qualquer pessoa interessada ${ }^{2}$ e, assim, o reavivamento de fatos passados de forma descontextualizada em relação à condição presente das pessoas a quem eles se referem, causando-lhes dores, constrangimentos e prejuízos de variada ordem. Sob tal circunstância, a liberdade mesmo do indivíduo parece ficar limitada, já que os fatos passados, por mais irrelevantes que sejam no presente (e por mais relevantes que tenham sido no passado - se é que foram relevantes em tal época pretérita), passam a figurar como uma letra escarlate que estigmatiza indelevelmente o indivíduo. Fica mais difícil obter "segundas chances" (COSTA, 2013).

Tem-se, pois, que a disseminação de tecnologias da informação, utilizadas diretamente pelos meios de comunicação de massa ou disponibilizadas por estes para uso por qualquer interessado, está a gerar problemas concretos que afetam diretamente as pessoas, inclusive em seu âmbito biopsíquico, e, portanto, está a desafiar os direitos fundamentais ou humanos $^{3}$. É justamente neste ponto que o discurso de um direito ao esquecimento, direcionado sobretudo (mas não exclusivamente) à "realidade digital", encontra terreno para crescer e se disseminar como mecanismo jurídico a ser acionado quando da ocorrência de ofensas como as acima destacadas.

Embora a ideia de esquecimento no direito não seja nova, ela ganhou contornos diferenciados com a ampliação das tecnologias de informação e comunicação, mormente com o desenvolvimento da internet, das redes sociais e, sobretudo, dos motores de busca de informações.

A compreensão acerca do direito ao esquecimento, contudo, não tem sido devidamente equacionada. Encontra-se algo limitada, pois várias das comunicações que procuram dar conta de seu fenômeno o fazem para puramente criticá-lo, como uma ameaça

\footnotetext{
2 Rosen (2010) refere-se a uma pesquisa feita pela Microsoft que aponta que $75 \%$ dos recrutadores e profissionais de recursos humanos dos Estados Unidos informaram que suas companhias solicitam que eles façam pesquisas online sobre os candidatos, sendo que para muitos o escrutínio envolve buscas numa série de variados sites (motores de busca, redes sociais, sites pessoais, sites de compartilhamento de fotos e vídeos, blogs etc.). Ainda segundo Rosen, 70\% dos recrutadores norte-americanos dizem ter rejeitado candidatos em virtude de informações encontradas online (como fotos, conversas e participação em grupos de natureza controversa).

${ }^{3}$ Considerando o posicionamento de Neves (2009, p. 253), no sentido de que os direitos humanos e os direitos fundamentais praticamente coincidem quanto ao conteúdo, variando, contudo, em seus âmbitos de pretensão de validade (os direitos fundamentais valeriam dentro de uma ordem constitucional estatal, enquanto os direitos humanos teriam pretensão de validade nas diversas ordens jurídicas existentes na sociedade mundial), os termos serão aqui utilizados de forma intercambiável, já que qualitativamente o direito ao esquecimento não variaria usando-se uma ou outra expressão.
} 
que levará à censura, ao apagamento de eventos históricos ou ao encobrimento de pedófilos, corruptos e outros criminosos, criando-se buracos negros informacionais na memória e na história. Sabe-se da impossibilidade de se controlar aprioristicamente os usos que serão dados aos institutos e que, nesse sentido, riscos existem. Contudo, o apontamento de tais perigos, sem a devida compreensão não só do contexto de surgimento, mas também dos elementos delimitadores do direito ao esquecimento, termina por jogar sombras sobre os problemas concretos que de fato estão a ocorrer e para cuja solução tal mecanismo tem sido mobilizado.

Há estudos que procuram compreender o direito ao esquecimento, inclusive no tocante à sua renovada faceta. Tais análises são válidas (como também o são evidentemente os apontamentos críticos), pois indicam dados relevantes para a composição de sua caracterização. Todavia, eles terminam, ao final, por se fixarem em elementos fortemente dogmáticos e na maneira de equacioná-los na prática. Afirmam, assim, que o direito ao esquecimento tem raiz na privacidade e na dignidade humana e que ele deve ser sopesado ou ponderado nos casos concretos em face do direito à informação e da liberdade de imprensa. Embora os estudos dogmáticos (e a discussão de seu conteúdo em si) sejam importantes, não se verifica, contudo, uma análise mais abrangente, que procure situar o problema em termos globais - já que a internet, os motores de busca, a mídia de massa e as comunicações são fenômenos globais que não podem ser devidamente compreendidos em termos puramente territoriais e mesmo jurídicos. Sente-se a ausência de uma análise sistêmica, mais ampla, que encare a realidade dos problemas concretos e dos discursos que procuram dar conta deles sob um enfoque global e mais sociológico.

Daí que o problema que surge é o seguinte: qual o papel do discurso do chamado "direito ao esquecimento" na sociedade? Qual o contexto de seu surgimento? O que o caracteriza? É possível localizá-lo ou relacioná-lo em face do sistema dos meios de comunicação de massa? Se o direito ao esquecimento é um direito fundamental ou humano, que papel ele desempenha?

Da maneira como colocado o problema, sua apreciação demanda um marco teórico que reconheça que a sociedade se diferencia em sistemas distintos, que atuam com função e lógica próprias, que não respeitam as tradicionais fronteiras territoriais estatais e cujas operações podem expandir-se a ponto de avançar sobre as pessoas e sobre sua integridade biopsíquica. Nesse sentido, parece promissor trazer à discussão autores vinculados 
à tradição da teoria dos sistemas, como Niklas Luhmann, Marcelo Neves e Gunther Teubner, evidentemente que não de maneira exaustiva, mas naqueles pontos que mais diretamente interessam e convergem em torno da discussão acerca do direito ao esquecimento. $\mathrm{O}$ pensamento de Luhmann adquire maior destaque no tocante às modificações técnico-sociais surgidas, à memória e ao delineamento e dinâmica dos meios de difusão, mormente do sistema dos meios de comunicação de massa. Já o pensamento de Neves é mobilizado sobretudo como fio condutor para a discussão (com aportes de Teubner) acerca do papel dos direitos fundamentais e direitos humanos no marco do pensamento sistêmico.

Se hoje, com as atuais tecnologias digitais, parece ter havido uma mudança no sentido de que tudo é lembrado e nada é esquecido, de forma que qualquer informação, mormente no tocante a dados pessoais, por mais velha e desatualizada que seja, pode ser resgatada de suportes de memória externos e ilimitados, de forma descontextualizada e sem limites (seja territoriais, seja em termos de finalidade), gerando danos e prejuízos a pessoas específicas, e que tudo isso encontra-se viabilizado e apropriado pelos meios de comunicação de massa (atuantes também na internet), parece haver uma conexão entre todo esse contexto e a ideia de se questionar o reuso ou a reutilização que se faz de informações passadas que contenham dados pessoais. Poderiam tais informações ser reutilizadas? Se sim, em que situações isso seria possível? Para quais finalidades? Em que casos as informações deveriam ser "esquecidas"?

A hipótese de trabalho que surge, sob tais colocações, é a de que o discurso do chamado direito ao esquecimento estaria se configurando como uma reação dos direitos fundamentais (ou humanos) aos efeitos destrutivos do sistema dos meios de comunicação de massa, cuja expansão estaria avançando a ponto de causar danos às pessoas, em sua dignidade, personalidade e substrato biopsíquico. O direito ao esquecimento, assim, configuraria um mecanismo destinado à proteção de tais aspectos da pessoa, assegurando um espaço comunicativo de autonomia perante os meios de comunicação de massa, a partir do qual poder-se-ia deduzir pretensões de questionamento quanto ao uso (ou reuso) que é feito das informações, evitando ou mesmo procurando remediar a ocorrência de eventuais instrumentalizações da pessoa por parte do sistema. 
A presente pesquisa tem como objetivos, assim, delimitar e apresentar, a partir da discussão de casos concretos paradigmáticos e de revisão bibliográfica sobre o tema, as características do chamado direito ao esquecimento, bem como demonstrar que tal discurso, nos seus contornos atuais, surge num contexto de reação dos direitos humanos em face da expansão e liberação de efeitos destrutivos dos meios de comunicação de massa sobre as pessoas.

Sabe-se que um tema pode ser analisado sob várias óticas. Com o direito ao esquecimento não é diferente. Envolvendo-o, várias discussões poderiam ser encetadas: a relação público-privado, a relação do direito com o tempo ou do direito com a história, a judicialização da própria (ideia de) história, os mecanismos jurídicos para solução de casos que envolvam direitos conflitantes (como a informação e a privacidade), as relações entre ordens jurídicas distintas na sociedade mundial etc. Considerando que cada análise dessa propiciaria o enredamento de um trabalho independente e autônomo, certo é que a apreciação que ocorrerá neste trabalho terminará por tocar ou perpassar alguns desses assuntos, de maneira a demonstrar a complexidade do tema e não com o intuito de aprofundá-lo em todas as suas nuanças. Nesse sentido, a própria demonstração dessa complexidade torna-se, em si, parte do objeto e do objetivo da presente pesquisa.

Para além da presente introdução, o trabalho compreende mais três capítulos de desenvolvimento e uma conclusão.

No Capítulo 1, buscar-se-á elencar e detalhar um rol de casos concretos que se apresentam paradigmáticos para a compreensão do direito ao esquecimento. O objetivo é mostrar a complexidade e as nuanças que o envolvem, bem como as diferenciações e as argumentações que são mobilizadas para construí-lo, a partir dos problemas concretos que se apresentaram para apreciação judicial.

O Capítulo 2 volta-se, de sua parte, à revisão bibliográfica e à discussão e caracterização do direito ao esquecimento, a partir dos elementos levantados com a análise dos casos concretos. A ideia é explorar o discurso do direito ao esquecimento, procurando identificar o contexto de seu desenvolvimento, seus contornos e os riscos geralmente levantados em função de sua adoção (possíveis ofensas à memória e à história, ao direito à informação etc.). 
O Capítulo 3, de sua sorte, buscará enfrentar a hipótese levantada, apresentando o delineamento dos meios de comunicação de massa, bem como o papel dos direitos humanos ou fundamentais numa sociedade (mundial) que se divide em sistemas funcionalmente diferenciados.

Cuida-se, enfim, de um trabalho que pretende se colocar como uma comunicação voltada a agregar mais elementos à compreensão de um fenômeno que não pode ser vulgarizado e que demanda análise mais detida, já que, além de suscitar discussões envolvendo direitos caros nas democracias atuais, como as liberdades de informação e de imprensa, arregimenta em torno de si problemas concretos de direitos humanos envolvendo as pessoas - incluindo o que elas tem de substrato biopsíquico, ou seja, o que elas tem de integridade de mente e corpo. 


\section{CAPÍTULO 1 - CASOS PARADIGMÁTICOS}

\subsection{Considerações preliminares}

A ideia do presente capítulo é a de relacionar e detalhar casos concretos envolvendo o direito ao esquecimento, de forma a evidenciar como os problemas surgem e como eles estão sendo resolvidos judicialmente com base nele. Almeja-se, com isso, expor as nuanças e complexidades intrínsecas aos problemas surgidos, de forma a extrair os elementos, as possibilidades, os riscos, enfim, a matéria-prima necessária ao delineamento do discurso do direito ao esquecimento em si.

Há casos concretos que não mencionam expressamente a nomenclatura do direito ao esquecimento. Por outro lado, o elenco de casos abarca situações envolvendo ora o ambiente virtual da internet, ora o ambiente televisivo. Ademais, há casos decididos por tribunais não só brasileiros, como também de outras jurisdições. Apesar de todas essas diferenciações entre eles, a escolha não se apresenta arbitrária - embora se saiba da impossibilidade de se ser ontologicamente exaustivo e da existência de contingências próprias da pesquisa e da definição das fontes.

Os casos são paradigmáticos, pois, ou tocam diretamente em elementos estruturantes do discurso do direito ao esquecimento, surgidos de embates envolvendo diretamente a privacidade e a proteção de dados dos indivíduos, ou fazem referência entre si, a ponto de discutirem pontos comuns que certamente adentram na configuração dos problemas e na caracterização e operacionalização do direito ao esquecimento, mormente na internet.

A diferença de jurisdições e de meios tecnológicos (com referência a casos televisivos e também relativos ao meio virtual da internet), em verdade, tende a figurar como algo positivo para o trabalho, pois evidencia diferenças que não fazem diferença em princípio, à luz de um marco teórico sistêmico (aqui adotado), que parte do reconhecimento da existência de uma fragmentação da sociedade mundial em subsistemas sociais globais 
funcionalmente diferenciados - dentre os quais se incluem os meios de comunicação de massa.

A ausência do uso de uma denominação (ou de uma mesma denominação) para o fenômeno que se pretende analisar também não configura um problema em si. Embora o uso de denominações ou mesmo metáforas seja algo importante - pois possibilita que se diga (ou não), adequadamente (ou não), muito a respeito do que se fala, tem-se que a nomenclatura não é algo distintivo de um fenômeno em si. Importa mais, como será evidenciado, a semelhança fenomênica dos problemas concretos, a identificação de argumentações recorrentes e a recursividade das comunicações envolvidas.

\subsection{O caso Lebach}

Em 1973, o Tribunal Constitucional Federal Alemão julgou o caso hoje conhecido como "Lebach".

Numa breve retrospectiva dos fatos, tem-se que, em 1969, quatro soldados que vigiavam um depósito de munição em Lebach (lugarejo situado no oeste da então República Federal da Alemanha) foram brutalmente assassinados e armas e munições foram roubadas. À época de sua ocorrência, o crime teve ampla cobertura pela imprensa e pela televisão locais. Os dois principais acusados foram condenados à prisão perpétua, sendo que um terceiro, coadjuvante que os auxiliara na preparação da ação criminosa, foi condenado a seis anos de reclusão.

Considerando o interesse despertado pelo caso na opinião pública, o canal de televisão alemão ZDF (Zweites Deutsches Fernsehen) produziu um documentário que cobria todo o ocorrido, apresentando os condenados - inclusive o coadjuvante - com fotos e nomes, além de detalhar as relações pessoais que mantinham entre si (incluindo ligações homossexuais). O documentário estava destinado a ir ao ar numa sexta-feira à noite, pouco antes da soltura do condenado coadjuvante - o qual, em vista disso, pleiteou judicialmente medida que impedisse a transmissão. 
Não logrando êxito em instâncias inferiores, o reclamante recorreu ao Tribunal Constitucional Federal, que conheceu do caso como um conflito entre a liberdade de radiodifusão e a proteção da personalidade, direitos que demandam, segundo a corrente adotada pela referida corte, ponderação entre si, já que ambos configuram valores essenciais à ordem democrática constitucional livre, não prevalecentes um sobre o outro a priori.

O tribunal reconheceu que a liberdade de radiodifusão engloba a seleção do conteúdo a ser apresentado, o tipo e o modo da respectiva apresentação (incluindo-se a forma do programa), não importando, sob tal lógica, "o interesse perseguido pelo programa concreto, o tipo e o modo de configuração e o efeito atingido ou previsto"4, exceto quando tais configurações colidam com outros bens jurídicos, como é o caso da proteção à personalidade.

Da ponderação, o tribunal assentou que, diante de noticiário atual sobre delitos graves, o interesse da população pela informação deve em geral prevalecer sobre o direito de personalidade do criminoso. Contudo, de acordo com o princípio da proporcionalidade e com a necessidade de respeito à mais íntima e intangível área da vida, a divulgação de nome, foto ou outra identificação do criminoso nem sempre é permitida. A proteção à personalidade impede que a televisão aborde a pessoa do criminoso e sua vida privada por tempo ilimitado e superior à atualidade da notícia.

Um noticiário posterior será, de qualquer forma, inadmissível se ele tiver o condão, em face da informação atual, de provocar um prejuízo considerável novo ou adicional à pessoa do criminoso, especialmente se ameaçar sua reintegração à sociedade (re-socialização). A ameaça à re-socialização deve ser em regra tolerada quando um programa sobre um crime grave, que identificar o autor do crime, for transmitido [logo] após sua soltura ou em momento anterior próximo à soltura ${ }^{5}$.

Com isso, o tribunal cassou as decisões das instâncias inferiores e proibiu a transmissão do documentário até decisão final a ser exarada na ação principal que tramitava sobre o caso.

\footnotetext{
${ }^{4}$ BverfGE 35, 202 - LEBACH. Excertos disponíveis em: MARTINS, Leonardo (org). Cinquenta anos de jurisprudência do Tribunal Constitucional Federal Alemão. Montevidéu: Konrad-Adenauer-Stiftung, 2005, p. 486-493.

${ }^{5}$ BverfGE 35, 202 - LEBACH. Excertos disponíveis em: MARTINS, Leonardo (org). Cinquenta anos de jurisprudência do Tribunal Constitucional Federal Alemão. Montevidéu: Konrad-Adenauer-Stiftung, 2005, p. 486-493.
} 


\subsection{Os Recursos Especiais $n^{\circ} 1334097 / R^{2}$ e $n^{0} 1335153 / R J$}

Muito tempo depois, já no Brasil, no ano de 2013, o caso Lebach foi expressamente inserido na fundamentação dos Recursos Especiais - RESP nº 1334097/RJ e RESP no 1335153/RJ, por meio dos quais o Superior Tribunal de Justiça - STJ reconheceu a existência do chamado direito ao esquecimento.

No RESP $n^{0} 1334097$, o caso de fundo dizia respeito ao pedido de reparação por danos morais sustentado em face da TV Globo, tendo em vista esta ter veiculado programa televisivo (Linha Direta - Justiça) sobre a "Chacina da Candelária", expondo em rede nacional a imagem e o nome do autor - envolvido na chacina, mas ao final absolvido por unanimidade pelo júri em virtude do reconhecimento de negativa de autoria. $\mathrm{O}$ autor aduziu que tal exposição de sua imagem e nome, sem consentimento, foi ilícita, pois ferira seu direito à paz, anonimato e privacidade pessoal, com prejuízo inclusive aos seus familiares. A veiculação do episódio no programa teria, assim, reacendido, na comunidade de sua residência, a imagem de chacinador, a desconfiança de todos e o ódio social, causando-lhe vários problemas, como inadmissão em emprego e ameaças de morte, que o obrigaram a desfazer-se de seus bens e a deixar a comunidade em que vivia, no intuito de proteger sua família e de não ser morto por justiceiros e traficantes.

Em primeira instância, seu pedido indenizatório foi julgado improcedente, tendo a respectiva sentença, contudo, sido reformada em grau de apelação, oportunidade em que o Tribunal de Justiça do Rio de Janeiro entendeu configurado o abuso do direito de informar e violado o direito de imagem do cidadão que, envolvido lateral e acessoriamente num evento que podia ser recontado sem a menção de seu nome, já havia voltado ao anonimato.

Irresignada com a decisão, a TV Globo interpôs o recurso especial perante o STJ, o qual, contudo, teve seu provimento negado por unanimidade pela $4^{\mathrm{a}}$ Turma, restando mantida a condenação ao pagamento de $\mathrm{R} \$ 50.000,00$ a título de indenização.

No segundo RESP n 1335153 , os irmãos vivos de Aida Curi pleitearam reparação por danos morais, materiais e de imagem igualmente em face da TV Globo, pelo fato, em síntese, desta emissora ter veiculado programa televisivo (novamente o Linha Direta Justiça), contrariamente a pedido dos autores, que explorara o trágico homicídio de sua irmã, 
ocorrido em 1958 - caso que se tornou nacionalmente conhecido em virtude da cobertura do noticiário da época e do processo criminal decorrente. Foi sustentado que o crime já havia sido esquecido com o passar do tempo e que a nova cobertura realizada pelo programa tantos anos depois teria reaberto feridas antigas dos autores, fazendo-os reviver dores do passado que justificariam indenização por danos morais. Ademais, a exploração comercial da imagem da falecida, de sua vida, morte e pós-morte, configuraria enriquecimento ilícito e dano material e de imagem também justificadores de indenização.

Os pedidos foram rejeitados em primeira instância. Apreciando a questão em grau recursal, o Tribunal de Justiça do Rio de Janeiro desproveu a apelação dos autores, mantendo a sentença de improcedência de primeiro grau. $\mathrm{O}$ tribunal apontou, inclusive, que os fatos expostos no programa eram e são de conhecimento público, eis que amplamente divulgados pela imprensa e discutidos e noticiados ao longo dos últimos cinquenta anos, inclusive nos meios acadêmicos. O tribunal destacou, ainda, que a TV Globo cumpriu com sua função social de informar, alertar e debater o caso, sendo estes deveres dos meios de comunicação que se sobrepõem ao interesse individual. Ademais, não teria havido - ou, pelo menos, não teria sido demonstrado - o aumento de lucro da ré com o uso do nome e da imagem da falecida.

Irresignados, os autores interpuseram recurso especial para o STJ, o qual, porém, não foi provido, por decisão de maioria da $4^{\mathrm{a}}$ Turma.

Embora as conclusões dos julgamentos dos dois casos sejam distintas - no RESP n 1334097 , o STJ “deu razão" ao autor, enquanto no RESP no 1335153 “deu razão” à TV Globo -, a fundamentação do voto condutor do Ministro-relator, em ambos, no geral (salvo a parte final), é a mesma. Ele enxerga os casos como confrontos entre a liberdade de informação/expressão/imprensa e os direitos de personalidade (dignidade da pessoa humana, privacidade, intimidade, imagem), construindo sua fundamentação para reconhecer a existência do direito ao esquecimento tanto a partir da legislação positiva infraconstitucional, quanto de aportes doutrinários e jurisprudenciais - nacionais e estrangeiros.

No que os votos condutores, proferidos pelo Ministro Luís Felipe Salomão, relator de ambos os casos, têm em comum no tocante ao mérito, cumpre destacar vários aspectos. 
De saída, o Ministro-relator aponta uma diferenciação com relação a muitos dos casos já anteriormente analisados pela corte envolvendo publicações jornalísticas e direitos de personalidade, os quais tinham como elementos factuais um contexto de ilicitude da publicação (conteúdo difamatório ou inverídico) e um cenário de contemporaneidade da notícia. Nos casos presentes, contudo, as controvérsias centram-se na ausência de contemporaneidade da notícia de fatos passados, os quais, revividos extemporaneamente e lembrados contra a vontade dos interessados, reativam e reabrem dores, estigmas e feridas já anteriormente superadas.

Outro ponto diz respeito ao intuito de limitar os efeitos da decisão aos casos de publicações em mídia televisiva, deliberadamente não se voltando, portanto, para a internet. Segundo o relator, o ambiente da internet teria contornos diferenciados e mais complexos, haja vista que não propicia o esquecimento do que é divulgado, que produz resíduos informacionais que superam a contemporaneidade da notícia, e que, assim, pereniza informações tanto aviltantes quanto honoráveis das pessoas ${ }^{6}$. Ele destaca que a discussão do tema no ambiente da internet alcança interesses de mais de um Estado-nação, reclama soluções (legislativas ou judiciais) específicas e desafia soluções de ordem técnica. A própria possibilidade de compartilhamento e circulação internacional de conteúdos apontaria, de acordo com ele, para tópicos sensíveis, como a questão da soberania dos Estados-nação. Assim, na decisão, o direito ao esquecimento é apreciado especificamente sob o viés "mais simplificado" das publicações em televisão.

O voto cuida ainda de apontar exemplificativamente o que seriam os principais argumentos levantados contra o direito ao esquecimento. Considerando-se o caráter enumerativo do tópico, permite-se a sua transcrição:

\footnotetext{
${ }^{6}$ Nesse contexto, o voto condutor pontua que a União Europeia, mesmo já tendo adotado a Diretiva ${ }^{\circ}$ 46/1995/CE (normatização que busca proteger pessoas no tocante ao tratamento de dados pessoais e à livre circulação da informação), viu reacender "o debate acerca da perenização de informações pessoais em poder de terceiros, assim como o possível controle de seu uso - sobretudo na internet", a ponto de a Vice-Presidente da Comissão de Justiça da União Europeia ter apresentado proposta de revisão das diretivas anteriores, de forma a se contemplar expressamente o direito ao esquecimento no âmbito da internet. (Conferir RESP 1334097/RJ e RESP 1335153/RJ, Rel. Ministro Luis Felipe Salomão, 4a Turma, julgados em 28/05/2013, DJe 10/09/2013).
} 
6. Grosso modo, entre outras assertivas contrárias à tese do direito ao esquecimento, afirmam-se que: i) o acolhimento do chamado direito ao esquecimento constitui atentado à liberdade de expressão e de imprensa; ii) o direito de fazer desaparecer as informações que retratam uma pessoa significa perda da própria história, o que vale dizer que o direito ao esquecimento afronta o direito à memória de toda a sociedade; iii) cogitar de um direito ao esquecimento é sinal de que a privacidade é a censura do nosso tempo; iv) o mencionado direito ao esquecimento colidiria com a própria ideia de direitos, porque estes têm aptidão de regular a relação entre o indivíduo e a sociedade, ao passo que aquele finge que essa relação não existe - "um delírio da modernidade"; v) o direito ao esquecimento teria o condão de fazer desaparecer registros sobre crimes e criminosos perversos, que entraram para a história social, policial e judiciária, informações de inegável interesse público; vi) ou uma coisa é, na sua essência, lícita ou é ilícita, não sendo possível que uma informação lícita transforme-se em ilícita pela simples passagem do tempo; vii) quando alguém se insere em um fato de interesse coletivo, mitiga-se a proteção à intimidade e privacidade em benefício do interesse público e, ademais, uma segunda publicação (a lembrança, que conflita com o esquecimento) nada mais faz do que reafirmar um fato que já é de conhecimento público; viii) e, finalmente, que programas policiais relatando acontecimentos passados, como crimes cruéis ou assassinos célebres, são e sempre foram absolutamente normais no Brasil e no exterior, sendo inerentes à própria atividade jornalística ${ }^{7}$.

Após a indicação dos referidos argumentos contrários ao direito ao esquecimento, o relator passa, então, a rebater as principais oposições elencadas.

$\mathrm{O}$ voto condutor aponta existir, na atualidade, um esgarçamento da intimidade $\mathrm{e}$ da privacidade, oriundo de um contexto social de modificações na relação público-privado e marcado por uma enxurrada de questões privadas no espaço público, seja em decorrência de atitudes espontâneas dos indivíduos, seja a partir da expropriação da intimidade e privacidade por parte de terceiros. Tal cenário estaria a impor novas reflexões sobre velhos direitos ou mesmo a configuração de novos direitos.

Quanto à alegação de censura, o relator destaca que a liberdade de imprensa encontra-se indissoluvelmente vinculada a todo e qualquer Estado de Direito, afigurando-se um dos pilares da democracia. Todavia, e não obstante os antigos fantasmas de perseguição e

7 RESP 1334097/RJ e RESP 1335153/RJ, Rel. Ministro Luis Felipe Salomão, 4 ${ }^{\mathrm{a}}$ Turma, julgados em 28/05/2013, DJe 10/09/2013. 
tolhimento vivenciados pela imprensa (brasileira) em tempos anteriores - os quais não devem ser esquecidos -, não se deve admitir uma atividade informativa desatada de princípios e regras (como os dispostos no artigo 220 e seguintes da Constituição Federal de 1988 - CF/88, que protegem a privacidade das pessoas, dentre outros bens jurídicos). Considerando que os direitos não são, em regra, absolutos, entende o relator, assim, que a liberdade de informação não pode apresentar-se hipertrofiada, às custas do atrofiamento dos valores que protegem a pessoa humana. Ele afirma que a $\mathrm{CF} / 88$ possui vocação antropocêntrica, radicada na dignidade da pessoa humana e que, portanto, no conflito entre liberdade de informação e direitos de personalidade, haveria de regra uma constitucional inclinação ou predileção para soluções protetivas da pessoa humana - embora a solução a prevalecer deva sempre observar as peculiaridades do caso concreto.

No tocante à perda de historicidade - que incluiria a possibilidade de crimes e criminosos históricos desaparecerem -, o voto condutor reconhece que a história de uma sociedade é patrimônio imaterial que alberga variados acontecimentos e personagens, os quais ensejam lembrança em função de inúmeras razões, incluindo a revelação de um senso de evolução ou regressão no tocante ao respeito a valores éticos e humanos. O caráter histórico da notícia jornalística policial, contudo, deveria ser visto com cautelas, em virtude da possibilidade de se ter uma historicidade artificialmente gerada em função de exploração midiática exacerbada, estigmatizada e interessada. O relator chega mesmo a transcrever trechos de estudos que apontam para as disfuncionalidades promovidas pela lógica (empresarial) que guia a atividade de imprensa (como a eleição de pautas por critérios políticos e não técnicos; a definição de "verdades" que na realidade significam uma versão dos fatos, mediada pela linha editorial do veículo de imprensa etc.), destacando ainda a poderosa influência que a exploração midiática exerce sobre os processos judiciais criminais. É nesse contexto de possibilidade de criação de historicidades por atuação abusiva e populista da mídia que o relator admite que a própria historicidade de um crime possa ser discutida ou ponderada em cada caso, inclusive no tocante a eventual artificiosidade criada à época da cobertura dos fatos propriamente ditos. Nesse cenário, a "historicidade" de um fato não poderia ser um elemento em si intransponível, a bastar por si próprio para permitir que crimes e indivíduos neles envolvidos possam ser retratados ampla, irrestrita e indefinidamente no tempo. 
O voto condutor toma em consideração ainda a questão do interesse público, apontando que ele não deve ser confundido com o interesse do público, que ele compreende legitimamente a publicidade a ser dada às respostas estatais para os fenômenos criminais, e que, contudo, ele nem sempre deve prevalecer sobre a privacidade ou intimidade dos envolvidos, sob pena de ofensa à Constituição.

Os fenômenos do tempo e do direito também são analisados. Segundo a decisão, tempo e direito encontram-se intrinsecamente relacionados, de forma que o direito confere significados à passagem do tempo, enquanto o tempo em si interfere na própria manifestação do direito. Evitando que o tempo se torne algo puramente cronológico, gerador de desestabilização da vida por meio de constantes surpresas, o direito procura estabilizar o passado e conferir previsibilidade ao futuro, havendo uma série de institutos em tal sentido, como a prescrição (um esquecimento programado); coisa julgada; anistias; respeito ao direito adquirido; a limitação de prazo para que dados negativos sobre inadimplência de consumidores figurem em bancos de dados; o sigilo da folha de antecedentes para condenados que já cumpriram a pena; a exclusão, dos terminais dos institutos de identificação criminal, de registros de dados acerca de inquéritos arquivados, de ações penais trancadas, de processos que tenham culminado em absolvição etc.

A assertiva de que uma notícia lícita não se transforma em ilícita com o simples passar do tempo não tem nenhuma base jurídica. O ordenamento é repleto de previsões em que a significação conferida pelo Direito à passagem do tempo é justamente o esquecimento e a estabilização do passado, mostrando-se ilícito sim reagitar o que a lei pretende sepultar ${ }^{8}$.

E todo esse esquecimento pode decorrer justamente em nome do respeito à privacidade. É nesse ponto do voto, aliás, que o caso Lebach é resgatado e tomado em consideração, juntamente com outros ${ }^{9}$, para demonstrar as diretrizes concernentes ao uso da informação de forma atual e, portanto, limitada no tempo, e os prejuízos adicionais ou novos aos direitos de personalidade que podem advir de um noticiário posterior não mais condizente com a atualidade dos fatos.

\footnotetext{
8 RESP 1334097/RJ e RESP 1335153/RJ, Rel. Ministro Luis Felipe Salomão, 4a Turma, julgados em 28/05/2013, DJe 10/09/2013.

${ }^{9}$ Outros dois casos estrangeiros são mencionados: o Caso Marlene Dietrich (julgado no Tribunal de Paris) e o caso Melvin vs. Reid (julgado no Tribunal de Apelação da Califórnia).
} 
É na esteira da relação entre tempo e direito que os limites da liberdade de informar são analisados. Destaca-se que a verdade ou a verossimilhança das informações veiculadas afigura-se como um requisito interno da liberdade de imprensa, fazendo com que a liberdade de informar sucumba perante notícias inverídicas. Mas esse não é o único limite a ser observado pela liberdade de informar. Deve-se observar, ainda, a vida útil do interesse público na informação (vinculando-a, no caso penal, ao esgotamento da resposta estatal dada aos fatos). É dizer: nem tudo o que é verídico pode, simplesmente por sê-lo, ser divulgado ou “permanecer eternamente na memória da sociedade - não por seu natural armazenamento neuropsíquico, infenso a qualquer reação jurídica, mas por obra de veículos de informação"10. A informação possui uma vida útil atrelada à causa que legitima ou justifica sua divulgação, o que, no caso criminal, perfaz-se com a fiscalização social da resposta estatal dada aos fatos. Ultrapassada a vida útil da informação, seu novo uso "só pode ambicionar, ou um interesse histórico, ou uma pretensão subalterna estigmatizante, tendente a perpetuar no tempo as misérias humanas"11.

Ressalva-se, portanto, a possibilidade do uso das informações em abordagens genuinamente históricas, cujas narrativas demandam (sob pena de impraticabilidade) a identificação mesmo dos envolvidos.

O relator entende, assim, que entre a memória (a conexão do presente com o passado) e a esperança (a conexão do futuro com o presente), o ordenamento jurídico teria feito opção pela segunda, configurando-se o direito ao esquecimento como um verdadeiro direito à esperança.

Neste ponto, cessa a fundamentação idêntica dos dois casos, oportunidade em que o relator começa a analisar de fato as situações concretas.

No RESP n ${ }^{\circ}$ 1334097, ele reconhece que a Chacina de Candelária tornou-se um fato histórico que expôs ao mundo os problemas do país concernentes à precária proteção conferida às crianças e aos adolescentes, mas que, na hipótese, tal história poderia ser

\footnotetext{
10 RESP 1334097/RJ e RESP 1335153/RJ, Rel. Ministro Luis Felipe Salomão, 4a Turma, julgados em 28/05/2013, DJe 10/09/2013.

11 RESP 1334097/RJ e RESP 1335153/RJ, Rel. Ministro Luis Felipe Salomão, 4a Turma, julgados em 28/05/2013, DJe 10/09/2013.
} 
perfeitamente recontada sem que se fizesse uso e exposição em rede nacional da imagem e do nome do autor da ação. Nenhuma ofensa, seja ao autor (em sua dignidade), seja à liberdade de imprensa (em seu mister), teria ocorrido se o nome e a imagem do autor não tivessem sido veiculados. Reportando-se à fundamentação do acórdão da instância inferior, o voto destaca "não [ser] leviano supor que o nome e a imagem do autor só foram memorizados por pessoas de seu círculo de convivência, pois a enorme maioria dos telespectadores, minutos depois da exibição do programa, sequer lembraria o seu primeiro nome"12. Ademais, "não havia qualquer atualidade na revelação da identidade daquele homem acusado injustamente de tão bárbaro crime; não havia, tampouco, interesse público significativo na divulgação desse pormenor"13. A divulgação da matéria teria, de fato, em verdade, como já acima apontado, desencadeado consequências negativas diretas ao autor - como a desconfiança social em relação à sua pessoa, além de outros danos. Em virtude desse julgamento, há recursos da TV Globo pendentes de apreciação perante o Supremo Tribunal Federal - STF.

Já no RESP no 1335153 a solução foi distinta - e não unânime. Reconheceu-se que, tal como os ofensores, as vítimas de um crime e seus familiares também têm direito ao esquecimento, se assim o desejarem. Ou seja, possuem o direito de não serem submetidas desnecessariamente a lembranças de fatos passados que causaram dores e feridas, não se permitindo, portanto, que os canais de informação enriqueçam por meio de indefinida exploração das desgraças das pessoas.

De toda sorte, também em relação aos ofendidos e seus familiares incidiria a ponderação acerca da historicidade do crime, ou seja, acerca de como o caso tornou-se histórico. Na hipótese, o relator entendeu que o homicídio de Aida Curi não foi artificiosa ou abusivamente coberto na época pela mídia, tendo a vítima mesmo se tornado elemento indissociável do delito, de forma a tornar impraticável a sua narrativa omitindo-se a sua figura. Sob tal lógica, não se poderia retratar o caso Aida Curi, sem Aida Curi. Tomando por base a fundamentação do acórdão recorrido, o relator dá destaque à circunstância de que os fatos são discutidos e noticiados desde à época e até hoje de maneira pública, inclusive acadêmica, havendo mesmo mais de 470.000 registros de ocorrências sobre o caso oriundos de pesquisa no motor de busca do Google.

\footnotetext{
12 RESP 1334097/RJ, Rel. Ministro Luis Felipe Salomão, 4a Turma, julgado em 28/05/2013, DJe 10/09/2013.

${ }^{13}$ RESP 1334097/RJ, Rel. Ministro Luis Felipe Salomão, 4a Turma, julgado em 28/05/2013, DJe 10/09/2013.
} 
Doutro lado, o fato de se admitir um direito ao esquecimento em tese não daria, segundo o relator, ensejo a um imediato dever de indenizar, eis que se apresenta necessário demonstrar a ocorrência de um dano, o qual, no caso, não se fez presente. É que, tendo a matéria sido divulgada cinquenta anos depois dos eventos, não se poderia falar em ocorrência de um abalo moral, já que o tempo decorrido faz com que a dor mesmo vá diminuindo, de forma que pode causar um desconforto, mas não na intensidade que o abalo de antes. Em virtude disso, a indenização por dano moral restou negada.

A indenização pelo uso da imagem, de sua sorte, também foi negada, eis que a vítima não teria sido apresentada de forma degradante ou desrespeitosa e que também não teria havido uso comercial de sua imagem, uma vez que houve uma única exposição fotográfica. "Tal circunstância reforça a conclusão de que - diferentemente de uma biografia não autorizada, em que se persegue a vida privada do retratado - o cerne do programa foi mesmo o crime em si, e não a vítima ou sua imagem", apresentando-se, outrossim, “improvável que uma única fotografia ocasionasse um decréscimo ou acréscimo na receptividade da reconstituição pelo público expectador"14.

A divergência (vencida) apontou, contrariamente ao relator, que a conduta da emissora incidiria sim na proibição do uso de imagem para fins comerciais sem autorização, pois, afinal, o programa configuraria um teleteatro (e não uma peça jornalística, dada a ausência de atualidade da informação) produzido com intuito de lucro, que não teria retratado uma investigação ou documentário acerca da vida ou dos fatos envolvendo personagem da história do país ou mesmo uma pessoa política, famosa ou notória cujo modo de vida ensejasse mitigação do direito à intimidade. A vítima era pessoa comum da cidade do Rio de Janeiro e foi apresentada por meio de foto que a retratava morta, ensanguentada e abraçada a um dos irmãos (autor também da ação judicial). As encenações realizadas reproduziram cenas impactantes, chocantes e violentas, integrantes de um filme televisivo sem natureza jornalística, relevância social ou interesse público ou histórico, mas com evidente intuito econômico, criado a partir da história da família Curi.

\footnotetext{
${ }^{14}$ RESP 1335153/RJ, Rel. Ministro Luis Felipe Salomão, 4a Turma, julgado em 28/05/2013, DJe 10/09/2013;
} 
Em virtude dos recursos pertinentes, o caso dos irmãos de Aida Curi teve repercussão geral reconhecida pelo Supremo Tribunal Federal - STF, encontrando-se assim pendente de apreciação pela referida corte a tese em torno da possibilidade de um direito ao esquecimento (no âmbito civil), configurada a partir do conflito entre as liberdades de informação e expressão, concretizadas pelas atividades de órgãos de mídia e de imprensa, de um lado, e a dignidade da pessoa humana e a inviolabilidade da honra e da intimidade, de outro.

\subsection{O caso Google vs. Mario Costeja González}

Foi com base em interpretação da Diretiva $n^{0}$ 46/1995/CE, mencionada lateralmente na fundamentação dos julgados do STJ acima analisados, que, em 13 de maio de 2014, ao julgar o caso C-131/12, o Tribunal de Justiça da União Europeia decidiu uma série de questões prejudicais suscitadas pela Audiência Nacional da Espanha (tribunal com sede em Madrid e jurisdição sobre toda a Espanha) num caso que envolvia, de um lado, as empresas Google Spain SL e Google Inc. e, de outro, o cidadão Mario Costeja González e a Agência Espanhola de Proteção de dados - AEPD ${ }^{15}$.

Mario González é um cidadão espanhol (domiciliado na própria Espanha), que tornou-se devedor da Seguridade Social, a ponto de imóvel de sua propriedade ter sido arrestado para fins de pagamento da dívida. Em 19 de janeiro e 9 de março de 1998, dois anúncios foram publicados, então, no jornal espanhol La Vanguardia, divulgando a alienação em hasta pública do imóvel dele e de várias outras pessoas. Uma vez resolvido o problema da dívida e do arresto já há muito tempo, González identificou, contudo, que uma pesquisa por seu nome no motor de busca do Google (Google Search) continuava a apresentar na lista de resultados os links que direcionavam para as páginas do jornal La Vanguardia que continham os referidos anúncios de alienação.

\footnotetext{
${ }^{15}$ Sendo um ato do ano de 1995, a Diretiva $\mathrm{n}^{\circ}$ 46/1995/CE não foi promulgada no contexto atual de ampla disseminação das atuais tecnologias da informação, principalmente da internet. Considerando tal circunstância, a Audiência Nacional da Espanha levantou questionamentos prejudiciais perante o Tribunal de Justiça da União Europeia quanto ao alcance de tal normativo. A Corte Europeia respondeu aos questionamentos no bojo do caso C-131/12, a partir de uma leitura dos termos da Diretiva no 46/1995/CE à luz do contexto das atuais tecnologias de busca de informações na internet.
} 
Pelo fato de o caso já estar resolvido e, portanto, entendendo ser impertinente a referência a ele na atualidade, Mario González apresentou, em 5 de março de 2010, reclamação perante a AEPD em face de La Vanguardia Ediciones SL e em face de Google Spain e Google Inc, postulando que se ordenasse ao jornal La Vanguardia a supressão ou alteração das respectivas páginas, fazendo com que seus dados viessem a desaparecer, ou a adoção de determinadas medidas disponibilizadas pelos próprios motores de busca para proteger esses dados. Quanto às empresas Google Spain e Google Inc, solicitou ordem para delas obter a supressão ou ocultação de seus dados pessoais, fazendo com que eles deixassem de aparecer nos resultados de pesquisa e nos links para o La Vanguardia.

A AEPD indeferiu o pedido com relação à retirada das publicações das páginas do jornal La Vanguardia, haja vista que elas estariam legalmente justificadas, eis que oriundas do Ministério do Trabalho e dos Assuntos Sociais e almejariam dar a máxima publicidade à venda de imóveis em hasta pública, de forma a reunir o maior número possível de licitantes. No que tange ao pedido contra a Google Spain e a Google Inc., a AEPD o acatou, sob o entendimento de que os operadores de motores de busca devem submeter-se à legislação de proteção de dados, uma vez que atuam como intermediários da sociedade de informação e que são responsáveis pelo tratamento de dados que realizam. O acatamento do pedido suscitou recursos de ambas as empresas para a Audiência Nacional Espanhola. Esta, de sua sorte, decidiu suspender a instância e submeter à Corte da União Europeia várias questões prejudiciais concernentes ao alcance interpretativo da Diretiva n ${ }^{\circ} 46 / 1995 / C E$.

19 Este órgão jurisdicional expõe na decisão de reenvio que os referidos recursos suscitam a questão de saber quais as obrigações que incumbem aos operadores de motores de busca para efeitos da proteção dos dados pessoais das pessoas interessadas que não desejem que determinadas informações, publicadas em sítios web de terceiros e que contêm os seus dados pessoais que permitem ligar essas informações a essas pessoas, sejam localizadas, indexadas e postas à disposição dos internautas indefinidamente. A resposta a esta questão depende da forma como a Diretiva 95/46 (sic) deve ser interpretada, no contexto destas tecnologias que surgiram depois da sua publicação ${ }^{16}$.

Apreciando o problema, a Corte de Justiça da União Europeia definiu uma série de questões importantes.

\footnotetext{
${ }^{16}$ Acórdão no processo no C-131/12, Grande Seção, julgado em 13/05/2014.
} 
De acordo com a decisão, a atividade de um motor de busca (como o Google Search), consistente em encontrar informações disponibilizadas na internet por terceiros, indexá-las automaticamente, armazená-las temporariamente e, enfim, colocá-las, sob determinada ordem de preferência, à disposição de internautas interessados, configura "tratamento de dados pessoais" (quando evidentemente essas informações contiverem dados pessoais), sendo certo que o operador do motor de busca responsabiliza-se pelo tratamento que produz. O tribunal rechaçou a ideia de que os motores de busca seriam meros intermediários que recolhem de forma conjunta todo tipo de informações (não as distinguindo ou selecionando entre dados pessoais ou não), que já foram publicadas e que não são alteradas quando indexadas. Para a corte, o fato de o operador do motor de busca localizar e indexar outras informações não afasta a circunstância de que ele capta, indexa, armazena e disponibiliza informações pessoais, ou seja, que permitem identificar pessoas singulares. Doutro lado, o fato de as informações não serem alteradas não significa que não foram tratadas, já que a própria ideia de tratamento engloba qualquer operação (não necessariamente alteradora) realizada sobre dados pessoais, de forma automatizada ou não (tais como o recolhimento, a organização, a conservação, a recuperação, a utilização, a comunicação por transmissão, a difusão ou qualquer outra forma de se colocar à disposição etc.). Ademais, os operadores dos motores de busca possuiriam finalidades e meios de tratamento que não se confundem com as finalidades e os meios de tratamento dos editores das páginas de internet. Enquanto estes últimos disponibilizam informações numa página da internet, os operadores dos motores de busca potencializam de maneira decisiva a difusão global dos dados, uma vez que permitem que qualquer internauta a eles tenha acesso (inclusive os internautas que de outra forma não teriam acesso às páginas da internet onde os dados foram publicados), a partir de buscas pelo nome das pessoas. Os motores de busca organizam e agregam as informações da internet, facilitam o acesso a elas e permitem, no caso de pesquisas com nome de uma pessoa singular, que se obtenha uma visão global mais estruturada das informações sobre tal pessoa e que se estabeleça, daí, um perfil mais ou menos detalhado sobre ela. As atividades dos motores de busca, portanto, podem afetar "significativamente e por acréscimo à[s] dos editores de sítios web, os direitos fundamentais à vida privada e à proteção dos dados pessoais" $" 17$.

\footnotetext{
${ }^{17}$ Acórdão no processo n ${ }^{\circ}$ C-131/12, Grande Seção, julgado em 13/05/2014.
} 
Por outro lado, a corte reconheceu que o tratamento de dados ocorre no território de um Estado-membro da União Europeia (no caso, Espanha), ainda que na prática seja efetuado fora do Estado-membro em si (pela Google Inc., que explora o Google Search a partir dos Estados Unidos e sem intervenção da Google Spain nessa atividade), quando se considera que a empresa operadora (Google Inc.) cria no Estado-membro uma sucursal ou filial (Google Spain) com o objetivo de promover e vender espaços publicitários, em atividade dirigida aos habitantes desse Estado-membro. Entendeu-se que o tratamento dos dados pessoais ocorre no contexto da atividade publicitária/comercial desenvolvida pela filial, sendo certo, ainda, que os espaços publicitários são o meio que tornam o motor de busca economicamente rentável e que o próprio motor de busca configura-se no meio para a realização das atividades publicitárias - tanto que os resultados da pesquisa e a respectiva publicidade relacionada com os termos de pesquisa são exibidos simultaneamente na mesma página de internet. Há, assim, um vínculo indissociável entre as duas atividades e os dois estabelecimentos.

Quanto ao alcance da responsabilidade dos operadores dos motores de busca, entendeu-se, ademais, que o motor de busca deve suprimir da lista de resultados de uma pesquisa efetuada com base no nome de uma pessoa os links para páginas de terceiros que contenham informações sobre essa pessoa, mesmo diante da inexistência de prévio ou simultâneo apagamento do nome e das informações dessa pessoa nessas páginas da internet (se for o caso disso) e mesmo que as informações publicadas por terceiros nessas páginas sejam em si mesmas lícitas. Com tal posicionamento, o tribunal rechaçou a tese das empresas Google Inc. e Google Spain no sentido de que quaisquer solicitações para eliminação de informações deveriam ser direcionadas aos editores das respectivas páginas de internet, eis que eles é que tornam as informações públicas e detêm, assim, as condições de avaliar a licitude de suas publicações e os meios mais eficazes e menos restritivos para tornar essas informações inacessíveis.

Para tanto - e partindo do direito ao respeito à vida privada, do direito à proteção de dados pessoais e da análise da Diretiva $n^{\circ}$ 46/1995/CE -, a corte esclareceu que o interessado pode requerer a retificação, o apagamento ou o bloqueio não só de dados incompletos ou inexatos que estejam sendo tratados, mas também de dados cujo tratamento esteja a descumprir deveres como: necessidade de tratamento leal e lícito; recolhimento dos dados para finalidades determinadas, explícitas e legítimas, não podendo vir a ser tratados 
posteriormente de forma incompatível com tais finalidades, ressalvada a possibilidade de tratamento posterior para fins históricos, estatísticos ou científicos, desde que estabelecidas garantias para tanto; exatidão e, se necessário, atualização dos dados; conservação que permita a identificação das pessoas apenas durante o período necessário para a efetivação das finalidades para os quais os dados foram recolhidos ou para que são tratados posteriormente, dando-se garantias para proteção em caso de conservação por períodos mais longos, para fins históricos, estatísticos ou científicos.

O tratamento de dados pessoais demanda, ainda, que seja legítimo o interesse do responsável pelo tratamento ou do terceiro ou terceiros a quem os dados venham a ser comunicados, e desde que não prevaleçam os interesses ou direitos fundamentais (v.g. privacidade) da pessoa referida - que pode, inclusive, opor-se, a qualquer momento, por razões legítimas e preponderantes relacionadas com sua situação particular, a que os dados em questão sejam objetos de tratamento, salvo disposição normativa em sentido contrário. Coloca-se, sob tais condições, a necessidade de se averiguar (“ponderar”), no caso concreto e de maneira específica, todas as circunstâncias que permeiam a situação concreta da pessoa a quem os dados se referem, à luz dos direitos e interesses opostos envolvidos (privacidade, proteção de dados pessoais; direito de acesso à informação dos internautas; interesses econômicos do operador do motor de busca) e em busca de um justo equilíbrio entre eles. $\mathrm{O}$ tribunal afirma que, como regra geral, os direitos fundamentais da pessoa referida prevalecem sobre o direito dos internautas de ter acesso à informação. Tal equilíbrio, contudo, pode variar e depender, nas situações particulares, de elementos como a natureza das informações, a sensibilidade delas para a vida privada da pessoa a que se referem, o interesse do público em dispor dessa informação e o papel desempenhado pela pessoa na vida pública.

Ainda segundo o tribunal, os pedidos voltados ao não tratamento dos dados nas hipóteses em questão podem ser dirigidos pela pessoa interessada diretamente ao responsável pelo tratamento, que tem a obrigação de examiná-los e apreciá-los e, se assim entender, encerrar os tratamentos impugnados. Não havendo seguimento na análise dos pedidos por parte dos responsáveis pelo tratamento dos dados, o interessado poderá submeter a questão à respectiva autoridade de controle ou aos órgãos jurisdicionais, os quais possuem competência para determinar que um operador de motor de busca deve suprimir da lista de resultados de uma pesquisa efetuada a partir do nome de uma pessoa os links para páginas da internet de terceiros que contenham informações dessa pessoa, independentemente de o nome ou as 
informações dessa pessoa serem, por vontade própria do editor da página ou de ordem mesmo da autoridade de controle ou jurisdicional, suprimidas prévia ou simultaneamente da página da internet onde foram publicadas.

Para assim concluir, o tribunal reafirmou a diferença entre os tratamentos de dados pessoais efetuados no contexto das atividades de um motor de busca e aqueles realizados pelos editores de páginas da internet. Nesse sentido, destacou que uma busca pelo nome de uma pessoa singular envolve um tratamento de dados que gera uma lista de resultados que agrega numerosos aspectos de sua vida privada - os quais não poderiam (ou dificilmente poderiam) ser relacionadas sem o motor de busca -, e que permite, assim, o delineamento de um perfil da pessoa a partir de uma visão global estruturada de informações a seu respeito. Em termos de ingerência sobre os direitos fundamentais da pessoa singular, os motores de busca terminam por ir além dos editores de páginas da internet, eis que, afinal, eles conferem caráter de ubiquidade às informações obtidas numa lista de resultados de pesquisa, desempenhando, assim, um importante e decisivo papel de difusão das (referidas) informações na sociedade moderna.

Além disso, o tratamento pelo editor de uma página web, que consiste na publicação
de informações sobre uma pessoa singular, pode, se for o caso disso, ser efetuado
“para fins exclusivamente jornalísticos" e, deste modo, beneficiar, por força do
artigo $9^{\circ}$ da Diretiva $95 / 46$, de derrogações às exigências estabelecidas por esta, ao
passo que não parece ser esse o caso do tratamento efetuado pelo operador de um
motor de busca. Assim, não se pode excluir que a pessoa em causa possa, em
determinadas circunstâncias, exercer os direitos previstos nos artigos $12^{\circ}$, alínea b),
e $14^{\circ}$, primeiro parágrafo, alínea a), da Diretiva $95 / 46$ contra esse operador, mas não
contra o editor da referida página web $b^{18}$.

Ainda relativamente à diferença de tratamento de dados feita pelos editores de páginas da internet e os operadores dos motores de busca, deve-se apontar que os motivos ou interesses que animam cada um desses tratamentos e as consequências deles decorrentes para a vida privada da pessoa referida não são (necessariamente) coincidentes, podendo variar e, portanto, gerar soluções ponderativas distintas conforme o caso. Mesmo que haja eventuais coincidências, o caso concreto deverá ser analisado.

\footnotetext{
${ }^{18}$ Acórdão no processo no C-131/12, Grande Seção, julgado em 13/05/2014.
} 
A parte final da decisão cuida do alcance dos direitos da pessoa afetada. A esse respeito, o tribunal entendeu que o direito a não figurar em listas de resultados de pesquisas efetuadas em motores de busca a partir do nome independe de que a inclusão da informação sobre a pessoa cause-lhe de fato um prejuízo. Ainda que a publicação por terceiros seja originalmente lícita e que contenha informações verdadeiras, elas podem deixar de ser passíveis de indexação, não estando pressuposto para tanto que a inclusão da informação na listagem do resultado da pesquisa esteja de fato causando prejuízo à pessoa a que se refere. É que, ressalvada a conservação para fins históricos, estatísticos ou científicos, bem como razões especiais, como a natureza das informações ou o papel desempenhado pela pessoa na vida pública, o respectivo tratamento dos dados pessoais exatos, inicialmente lícito, pode se tornar ilícito com o passar do tempo, tendo em vista às finalidades para que foram recolhidos ou tratados. A incompatibilidade ou ilicitude em relação às finalidades originais do tratamento pode se concretizar pelo fato de os dados serem (ou terem se tornado) inadequados, não pertinentes, excessivos, desatualizados ou de terem sido armazenados por tempo superior ao necessário. Caso isso ocorra, o interessado tem o direito de postular que as informações e os links sobre a sua pessoa sejam suprimidos da lista de resultados - ou seja, que as informações não mais sejam associadas ao seu nome -, sem que para o reconhecimento de tal direito deva concorrer necessariamente a ocorrência de um prejuízo. Segundo a corte, não havendo razões especiais em sentido contrário, o direito fundamental à privacidade prevalece em princípio sobre o interesse econômico do operador do motor de busca e sobre o interesse do grande público. Tais condições, contudo, deverão ser apreciadas nos casos concretos.

\subsection{O Recurso Especial $n^{0} 1316921 / R J$ (caso Xuxa), a Reclamação $n^{0}$ 5.072/AC, a Reclamação n ${ }^{18.685 / E S ~ e ~ o ~ c a s o ~ E q u u s t e k ~ S o l u t i o n s ~ I n c . ~ v s . ~ G o o g l e ~ I n c . ~}$}

Para além dos casos paradigmáticos acima relatados, existem outros que merecem também ser destacados, para melhor compreensão do direito ao esquecimento em si e da sua operacionalização - sobretudo no âmbito virtual. 
Um dos casos mais relevantes é o Recurso Especial no 1316921/RJ, em que se discutiu problemática envolvendo a apresentadora Xuxa Meneghel e a empresa Google Brasil Internet Ltda.

$\mathrm{Na}$ raiz, tem-se que a apresentadora em questão entrou com ação judicial pleiteando do Google que removesse do Google Search resultados atrelados à busca pela expressão "xuxa pedófila", "ou, ainda, qualquer outra que associe o nome da autora, escrito parcial ou integralmente, e independentemente de grafia, se correta ou equivocada, a uma prática criminosa qualquer" ${ }^{\prime 19}$.

Apreciando pedido de tutela antecipada, o juiz de primeiro grau exarou decisão interlocutória determinando que o Google se abstivesse de disponibilizar aos usuários do Google Search quaisquer links ou resultados decorrentes de buscas pelos critérios "Xuxa", "pedófila", "Xuxa Meneghel", "ou qualquer grafia que se assemelhe a estas, isolada ou conjuntamente, com ou sem aspas", sob pena de multa de $\mathrm{R} \$ 20.000,00$, por cada resultado disponibilizado indevidamente ao usuário ${ }^{20}$.

A discussão da matéria passou pela via recursal no Tribunal de Justiça do Rio de Janeiro - que restringiu parcialmente a decisão anterior apenas às imagens expressamente aludidas pela apresentadora, e sem exclusão dos links na apresentação dos resultados de pesquisa -, tendo, enfim, chegado ao STJ por via de Recurso Especial interposto pelo Google, o qual teve por objeto justamente a determinação dos limites da responsabilidade de site de pesquisas da internet pelo conteúdo dos resultados que apresenta.

Unanimemente, a $3^{\text {a }}$ Turma do STJ decidiu, nos termos do voto da Ministrarelatora Nancy Andrighi, acatar o Recurso Especial e cassar a antecipação de tutela deferida, por ausência de interesse de agir da apresentadora Xuxa em face do Google. Para tanto, reconheceu-se que os provedores de pesquisa na internet (como o Google Search), configuram-se como meros intermediários de informações, que "não incluem, hospedam, organizam ou de qualquer outra forma gerenciam as páginas virtuais indicadas nos resultados", limitando-se à indicação dos links onde as expressões ou os termos procurados

\footnotetext{
${ }_{19}$ Recurso Especial no 1316921/RJ, Rel. Ministra Nancy Andrighi, 3 ${ }^{a}$ Turma, julgado em 26/06/2012, DJe 29/06/2012.

${ }^{20}$ Recurso Especial $n^{\circ}$ 1316921/RJ, Rel. Ministra Nancy Andrighi, $3^{\text {a }}$ Turma, julgado em 26/06/2012, DJe $29 / 06 / 2012$.
} 
podem ser encontrados ${ }^{21}$. Assim sendo, e como eles apenas facilitam a localização de informações - as quais, ainda que ilícitas, possuem acesso público e circulam livremente na internet - não podem ser responsabilizados pelo conteúdo das buscas efetuadas por seus usuários.

Na esteira da identificação dos motores de busca como meros provedores de pesquisa, e considerando ainda aspectos de alcance tecnológico - ligados a limitações técnicas que impediriam a identificação e distinção automática e antecipada de páginas lícitas ou ilícitas, ofensivas ou não a determinadas pessoas - não se afiguraria possível transferir para os referidos mecanismos de busca a incumbência de identificar antecipada ou previamente eventuais páginas de conteúdo ilícito (como imagens sensuais, íntimas, pornográficas) - até porque, aliás, a dinâmica da internet propicia modificações e atualizações constantes de suas páginas e de seu conteúdo (inclusive ilícito). Tal conclusão contrapõe-se ao argumento levantado de que seria mais fácil demandar os provedores de informação em si (por supostamente terem maior capacidade de identificar conteúdo ilícito), do que cada pessoa responsável por disponibilizar o respectivo conteúdo ilícito - como, no caso, imagens de cunho erótico da apresentadora.

A decisão posiciona-se, ainda, pela impossibilidade de os provedores de pesquisa serem obrigados a eliminar os resultados decorrentes de buscas por determinadas expressões, como, no caso, "Xuxa", "pedófila", "Xuxa Meneghel”. A medida, caso adotada, além de inócua, por não alcançar provedores de pesquisa localizados em outros países (que possibilitariam buscas e resultados semelhantes aos que se procura eliminar), terminaria por dificultar bastante a localização de quaisquer páginas com a palavra/expressão proibida, ainda que os conteúdos nelas veiculados fossem legais. E isso feriria o direito à informação.

Na hipótese específica dos autos, por exemplo, a proibição de que o serviço da recorrente aponte resultados na pesquisa da palavra "pedofilia" impediria os usuários de localizarem reportagens, notícias, denúncias e uma infinidade de outras informações sobre o tema, muitas delas de interesse público. A vedação restringiria, inclusive, a difusão de entrevista concedida recentemente pela própria recorrida, abordando a pedofilia e que serve de alerta para toda a sociedade. Curiosamente, a

${ }^{21}$ Recurso Especial no 1316921/RJ, Rel. Ministra Nancy Andrighi, $3^{\text {a }}$ Turma, julgado em 26/06/2012, DJe $29 / 06 / 2012$. 
vedação dificultaria até mesmo a divulgação do próprio resultado do presente julgamento!

(...)

A verdade é que não se pode, sob o pretexto de dificultar a propagação de conteúdo ilícito ou ofensivo na web, reprimir o direito da coletividade à informação.

Sopesados os direitos envolvidos e o risco potencial de violação de cada um deles, o fiel da balança deve pender para a garantia da liberdade de informação assegurada pelo art. 220, $\S 1^{\circ}$, da $\mathrm{CF} / 88$, sobretudo considerando que a Internet representa, hoje, importante veículo de comunicação social de massa ${ }^{22}$.

A decisão reputou, ademais, ser impossível impor aos provedores de pesquisa a obrigação de restringir os resultados das buscas realizadas, ainda que o interessado se valha não de expressões genéricas ou amplas, mas venha a indicar prévia e especificamente o conteúdo que reputa ilícito, por meio da indicação do respectivo caminho virtual da página da internet (ou seja, do URL - Universal Resource Locator da página). Em prol de tal entendimento, considerou-se sobretudo a prevalência do direito à informação e a ausência de interesse de agir do interessado em face do buscador, uma vez que, de posse do URL seria possível à vítima identificar e "acionar diretamente o autor do ato ilícito, com o que, julgado procedente o pedido e retirada da Internet a página, o respectivo conteúdo será automaticamente excluído do resultado das buscas realizadas junto a qualquer provedor de pesquisa"23.

Tendo ficado restrito o debate do caso Xuxa no STJ apenas ao alcance da responsabilidade de sites de pesquisa na internet pelo conteúdo dos resultados que apresentam, não houve qualquer discussão ou apreciação acerca da personalidade pública da apresentadora e da natureza dos dados envolvidos ${ }^{24}$.

\footnotetext{
22 Recurso Especial n ${ }^{\text { }}$ 1316921/RJ, Rel. Ministra Nancy Andrighi, $3^{\text {a }}$ Turma, julgado em 26/06/2012, DJe 29/06/2012.

${ }^{23}$ Recurso Especial $n^{\circ}$ 1316921/RJ, Rel. Ministra Nancy Andrighi, $3^{\text {a }}$ Turma, julgado em 26/06/2012, DJe 29/06/2012.

${ }^{24}$ É de se destacar, neste ponto, que a apresentadora não se insurgiu contra a decisão do Tribunal de Justiça do Rio de Janeiro que negou seguimento ao seu Recurso Especial, de sorte que a apreciação do caso ocorreu no STJ apenas sob o viés do Recurso Especial apresentado pelo Google.
} 
Para além da própria $3^{\mathrm{a}}$ Turma, o entendimento em questão foi, enfim, ratificado e pacificado no STJ quando da apreciação da Reclamação - RCL n ${ }^{\circ}$ 5.072/AC, julgada não por Turma, mas pela Segunda Seção daquela corte superior ${ }^{25}$. A Reclamação foi apresentada pela empresa Google Brasil Internet Ltda. com o intuito de obter a cassação ou reforma de decisão de instância inferior que havia mantido multa (astreintes) imposta em decorrência de suposto descumprimento de decisão liminar (prolatada em ação judicial de obrigação de fazer e indenização por danos morais movida contra a empresa por um juiz de direito), que determinava que fossem retirados dos resultados do Google Search não só o link indicado que direcionava para a reportagem original da Revista Istoé sobre juízes pedófilos, como outros que ligavam a outros sites/páginas que reproduziam a matéria, devendo suspender ainda dos seus mecanismos de busca os resultados oriundos da associação do nome do juiz autor da ação (Pedro Luis Longo) e suas variações (Pedro Luiz Longo e Pedro Longo) à matéria da revista Istoé em questão e suas reproduções ou ao tema pedofilia, pedófilos etc. O Google alegava, dentre outros pontos, a impossibilidade técnica de cumprimento da decisão judicial que originara a multa, eis que, em suma, não seria dono da internet e não teria, portanto, ingerência sobre sites de terceiros que estariam reproduzindo a matéria da Revista Istoé.

Como questão anterior à análise da manutenção, redução ou eliminação da multa imposta por descumprimento de decisão judicial, passou-se a discutir a responsabilidade dos provedores de pesquisa, oportunidade em que, após amplo debate, voltou-se a rearfirmar o entendimento já enfim esposado no Caso Xuxa, desta feita a partir de voto-vista da Ministra Nancy Andrighi, que não só abriu divergência com relação ao voto do Ministro-relator Marco Buzzi, como também serviu de voto-condutor para a maioria ao final formada. Acompanhando a maioria formada em torno do voto da Ministra Nancy Andrighi, o Ministro João Otávio de Noronha entendeu ser exagerado "acionar quem indexa ou faz o índice de pesquisa, no caso, o Google, e não quem publicou a matéria", acrescentando, ainda, ter sido a publicação da Revista Istoé a responsável por manchar a imagem do magistrado - e não o site de pesquisas, que não inventa, que não tem "nada a ver com o conteúdo da matéria" (que permanece no site de origem) e que busca aquilo que a rede disponibiliza ${ }^{26}$.

\footnotetext{
${ }^{25}$ A Segunda Seção do STJ é composta pelos ministros da $3^{\mathrm{a}}$ e $4^{\mathrm{a}}$ Turmas.

${ }^{26}$ RCL n ${ }^{o}$ 5.072/AC, Rel. Ministro Marco Buzzi, Rel. para Acórdão Ministra Nancy Andrighi, 2a Seção, julgado em 11/12/2013, DJe 04/06/2014.
} 
De toda sorte, a partir de observações trazidas pelo voto-vista da Ministra Isabel Gallotti, o acórdão final terminou por avançar e reconhecer uma exceção ao entendimento de que se determinada página possui conteúdo ilícito, caberá ao interessado/ofendido adotar medidas voltadas à supressão da referida página (que deverá estar devidamente identificada pelo URL), não havendo razão para demandar os motores de busca. Trata-se da situação em que, acionados diretamente os responsáveis pelos sites veiculadores de imagens ou textos ilícitos ou ofensivos e determinada a exclusão de tais conteúdos dos referidos sites (a partir da indicação clara de cada um dos URLs), os provedores de pesquisa poderão ser acionados caso ainda apresentem em seus resultados de busca os respectivos links para as páginas já retiradas dos sites de origem. A Ministra Isabel Gallotti aponta que isso pode de fato ocorrer, pois "sabe-se que o Google, para agilizar suas pesquisas, mantém, em seus servidores, "espelhos" dos sites, ou como prefere, "instantâneos de cada página como backup", o que se chama de armazenamento "em cache"" 27 . Como tais espelhos dos sites indexados são automática e periodicamente capturados (não se sabendo ao certo a frequência de tal operação), pode ocorrer de o site original já ter sido excluído e ainda assim ser possível, mesmo que temporariamente, localizá-lo a partir de buscas no Google, perdurando tal situação até que a supressão nos resultados de busca de fato ocorra após nova varredura atualizadora do sistema de indexação. Segundo a Ministra Isabel Gallotti, tal circunstância "pode prorrogar, como dito acima, não se sabe por quanto tempo, eventual dano já coibido com a retirada do ar da página original" 28 . Assim, conforme definido pelo STJ, o provedor de pesquisa pode ser obrigado a retirar dados ilícitos ou ofensivos armazenados em memória cache, dependendo tal obrigação da indicação do respectivo URL da página original, da comprovação de que tal página original já foi removida da internet e de decisão judicial expressa e determinada no sentido de que tal remoção ocorra.

Aplicando justamente o entendimento consolidado na Reclamação $n^{\circ}$ 5.072/AC, o Ministro Ricardo Villas Bôas Cueva monocraticamente julgou procedente a Reclamação RCL $n^{\circ}$ 18.685/ES, afastando condenação imposta ao Google no sentido de retirar determinado URL (link) dos resultados de pesquisas efetuadas a partir da inclusão do nome do interessado no critério de pesquisa. Tratava-se, na origem, de um juiz de direito que

\footnotetext{
${ }^{27}$ RCL no 5.072/AC, Rel. Ministro Marco Buzzi, Rel. para Acórdão Ministra Nancy Andrighi, $2^{\mathrm{a}}$ Seção, julgado em 11/12/2013, DJe 04/06/2014.

${ }^{28}$ RCL no 5.072/AC, Rel. Ministro Marco Buzzi, Rel. para Acórdão Ministra Nancy Andrighi, $2^{\mathrm{a}}$ Seção, julgado em 11/12/2013, DJe 04/06/2014.
} 
respondera a procedimento administrativo disciplinar e fora absolvido. Porém, "dentre as diversas notícias sobre o tema veiculadas na impressa (sic) local, indica que a reportagem divulgada pela Gazeta Online ainda estava vinculada ao seu nome no site de busca da Google" ${ }^{\text {29 }}$. Embora tenha decidido de maneira contrária à pretensão original do autor, é de se ressaltar o seguinte trecho da decisão do Ministro Ricardo Villas Bôas Cueva:

Destaca-se do julgado [de instância inferior], quanto à pretensão do autor, que "não
seria de censurar a matéria disponibilizada, mas a indexação do conteúdo da
matéria com a referência de seu nome junto ao buscador desenvolvido pela
GOOGLE. E, pouco importa para EDMILSON, creio, que outros provedores de
pesquisa viabilizem tal localização, ou mesmo acessem a página original da
publicação, pois seu objetivo dispõe-se exclusivamente em desfavor da GOOGLE,
pela relevância de sua atuação de mercado, de modo que deve ser respeitada sua
pretensão" (fls. 224, e-STJ) ${ }^{30}$.

Mais uma vez a questão foi discutida, no STJ, sob o viés da ausência de responsabilidade dos provedores de pesquisa - e não no tocante ao papel da pessoa na vida pública, à natureza dos dados envolvidos ou a outros critérios.

Outro caso digno de nota é o Equustek Solutions Inc. vs. Google Inc., julgado pela Corte de Apelações da Colúmbia Britânica (Província do Canadá) ${ }^{31}$. Embora não envolva, na origem, a privacidade, mas sim uma disputa em torno de apropriação indevida de informações confidenciais e violações a direitos de propriedade intelectual, sua relevância decorre do fato de o tribunal em questão ter ratificado decisão judicial interlocutória da Suprema Corte da Colúmbia Britânica que determinara à empresa Google Inc. que cessasse, em escala global, a indexação, nos resultados de pesquisa em seus motores de busca, de uma determinada listagem de sites de internet (não apenas determinadas páginas, mas os sites como um todo). Tratou-se de uma ordem incidentalmente dirigida à empresa Google Inc., a qual, contudo, não figurava como parte na lide principal (Equustek Solutions Inc. vs. Jack ${ }^{32}$ ).

\footnotetext{
29 Reclamação n ${ }^{\circ}$ 18.685/ES, Rel. Ricardo Villas Bôas Cueva, decisão monocrática de 05/08/2014, DJe 22/08/2014.

30 Reclamação $n^{\circ}$ 18.685/ES, Rel. Ricardo Villas Bôas Cueva, decisão monocrática de 05/08/2014, DJe 22/08/2014. Grifos do original.

${ }^{31}$ Equustek Solutions Inc. v. Google Inc., 2015 BCCA 265 (Can LII), julgado em 11/06/2015.

${ }^{32}$ Equustek Solutions Inc. v. Jack, 2014 BCSC 1063 (Can LII), julgado em 13/06/2014.
} 
$\mathrm{Na}$ origem da celeuma tem-se que a empresa Equustek Solutions Inc., fabricante de dispositivos de rede que permitem a interconexão ou comunicação entre equipamentos industriais complexos de diferentes fabricantes, foi alvo de práticas ilícitas de empresas e pessoas que, então parceiras, distribuíam seus produtos. Os acusados teriam passado não só a vender os produtos como se seus fossem, cobrindo o nome e o logotipo da Equustek Solutions Inc., como também teriam desenvolvido um produto concorrente, a partir de segredos industriais da empresa reclamante. Como os negócios passaram a ser feitos a partir de uma rede em expansão de sites de internet - nos quais os produtos eram anunciados e vendidos -, houve várias ordens judiciais dirigidas contra esses sites que culminaram, inclusive, na proibição dos acusados de realizarem negócios por meio de qualquer site de internet - o que não foi cumprido, dado o fato deles continuarem a vender o produto concorrente virtualmente.

Em seguida à decisão que proibiu a prática comercial em qualquer site, a empresa Google Inc., acatando voluntariamente solicitação da Equustek Solutions Inc., removeu páginas da internet especificas (URLs especificamente determinados) dos resultados de pesquisas feitas no âmbito do seu motor de busca canadense (google.com.ca), ou seja, de resultados de pesquisas originadas no Canadá. Considerando, contudo, que o Google Inc. adota a política de não retirar ou bloquear voluntariamente de seus resultados de busca domínios, subdomínios ou sites inteiros, mas apenas páginas específicas, e mesmo assim não de maneira global; que os acusados estariam redirecionando o conteúdo de páginas desindexadas para outras páginas dentro do mesmo site; e, ainda, que a maioria dos pedidos dos produtos seriam provenientes de interessados de fora do Canadá, a empresa Equustek Solutions Inc. postulou ordem judicial contra a Google Inc. para obter a desindexação, em escala mundial, dos sites das empresas envolvidas, haja vista que o motor de busca do Google estaria facilitando o descumprimento das decisões judiciais prolatadas. No contexto, destacase, inclusive, ter se tornado desconhecida a localização física dos réus - lugar a partir do qual eles fabricariam, armazenariam e enviariam os pedidos, parecendo mesmo que eles estariam mudando de localidade de tempos em tempos e que os pedidos estariam sendo atendidos de fora do Canadá. "De fato, os acusados parecem ter, para todos os efeitos, abandonado sua defesa" ${ }^{, 33}$.

\footnotetext{
${ }^{33}$ Equustek Solutions Inc. v. Google Inc., 2015 BCCA 265 (Can LII), julgado em 11/06/2015. Tradução nossa.
} 
Analisando a postulação da empresa Equustek Solutions Inc., a Suprema Corte da Colúmbia Britânica deferiu ordem judicial interlocutória proibindo o Google de incluir uma lista de sites dos acusados nos resultados apresentados pelos seus motores de busca em âmbito mundial. Como o Google não era parte da ação original, nem teria cometido qualquer infração, a ordem em questão adquiriu caráter cautelar, no sentido de garantir a efetividade das decisões já prolatadas. Na situação, o Google estaria, ainda que involuntariamente, facilitando o descumprimento de ordens judiciais por parte dos réus, os quais, por sua vez, estariam justamente contando com a facilidade proporcionada pelo motor de busca para atrair clientes em potencial, sendo certo que eles não teriam sucesso comercial se não pudessem ser localizados através dos serviços de busca do Google (que seria responsável por $70-75 \%$ das buscas realizadas na internet $)^{34}$.

A Corte de Apelação da Colúmbia Britânica admitiu o recurso da empresa Google Inc., mas indeferiu o pedido de efeito suspensivo direcionado à parte da decisão que determinava o bloqueio dos sites para além da plataforma canadense do Google (google.com.ca) ${ }^{35}$. O recurso foi, em si, ao final, julgado improcedente, restando mantida a decisão interlocutória de efeitos globais prolatada ${ }^{36}$.

Apesar de muitos pontos terem sido discutidos no caso Equustek (como a possibilidade do Google, não sendo parte do processo, ter ordem judicial contra si dirigida; a possibilidade dos efeitos dessa ordem serem globais; a competência territorial e material das cortes para deferi-la etc.), destaca-se a análise da atividade do motor de busca Google Search, inclusive mediante remissão e abordagem expressa do caso Google vs. Mario Costeja González, julgado pelo Tribunal de Justiça Europeu.

Contrapondo-se ao argumento do Google de que ele apenas forneceria um mero site de buscas na internet, que gera resultados automáticos (a partir de buscas nas trilhões de páginas na internet, segundo critérios algorítmicos confidenciais), sem qualquer envolvimento ativo numa pesquisa em particular, as cortes canadenses em questão concluíram que os sites de busca do Google não seriam meros sites de informação passiva. Para tanto, apontaram que o Google antecipa sugestões e quesitos de busca, à medida que o interessado começa a digitar;

\footnotetext{
${ }^{34}$ Equustek Solutions Inc. v. Jack, 2014 BCSC 1063 (Can LII), julgado em 13/06/2014.

${ }^{35}$ Equustek Solutions Inc. v. Google Inc., 2014 BCCA 295 (Can LII), julgado em 23/07/2014.

${ }^{36}$ Equustek Solutions Inc. v. Google Inc., 2015 BCCA 265 (Can LII), julgado em 11/06/2015.
} 
que tais sugestões tomam como base buscas anteriores do próprio interessado ou palavraschave mais comumente procuradas pelos internautas de uma maneira geral; e que o Google coleta uma série de informações à medida que alguém faz uma pesquisa (endereço de IP, localização, termos de busca, se o usuário clica nas sugestões de links apresentadas). As cortes apontaram ainda que os serviços de publicidade ou anúncios estariam intrinsecamente relacionados com os serviços de busca (um não se sustentando sem o outro), já que, sendo as pesquisas gratuitas, haveria em contrapartida a cobrança pela venda de espaços para divulgação de publicidade juntamente com os resultados de uma determinada busca. A publicidade que aparece, de sua sorte, encontra-se relacionada seja com os termos da pesquisa em si, seja com o histórico de buscas da pessoa.

Contra o deferimento da ordem, a empresa Google Inc. chegou a aduzir a impossibilidade prática de monitorar e decidir acerca da precisão ou legalidade do teor de sites, dado o enorme volume de dados e a constante mudança de conteúdos. Alegou ainda que desindexar sites inteiros sem analisar o teor das páginas (URLs) neles constantes configuraria censura e que uma ordem judicial de efeitos globais restritivos sobre as pesquisas poderia sujeitá-lo a ter de eventualmente descumprir o direito em outras jurisdições para dar cumprimento à ordem canadense. O entendimento jurisdicional, contudo, superou tais objeções no caso concreto, argumentando, em síntese, que a ordem judicial em questão não o colocaria no dever de monitorar o conteúdo dos sites dos acusados, mas sim na obrigação de remover tais sites - não se dirigindo, portanto, ao que está colocado, mas a quem colocou o conteúdo; doutro lado, além de acatar decisões judiciais - como as do caso presente, voltadas aos sites proibidos dos acusados -, o próprio Google teria reconhecido sua responsabilidade corporativa em alterar resultados de busca que possam gerar links para sites de pornografia infantil e veiculadores de discursos de ódio. Ademais, não teria havido a demonstração de que a ordem judicial almejada ofenderia o direito da Califórnia/EUA (onde a empresa Google Inc. tem sede) ou de outro estado ou país a partir dos quais pesquisas pudessem ser feitas, tendo o Google mesmo reconhecido que a maioria dos países provavelmente reconhece os direitos de propriedade intelectual, encarando a venda de produtos ilegais como algo errado ${ }^{37}$.

\footnotetext{
${ }^{37}$ Equustek Solutions Inc. v. Jack, 2014 BCSC 1063 (Can LII), julgado em 13/06/2014.
} 
Houve certa discussão quanto à possibilidade de uso dos sites bloqueados para o exercício da liberdade de expressão - e que o bloqueio, assim, inviabilizaria tal direito. A Corte de Apelação entendeu que, no caso concreto, tal preocupação seria apenas especulativa, dada a inexistência de evidências em tal sentido. De toda sorte, fez ressalvas quanto à possibilidade de haver provocação das partes interessadas com o intuito de modificar ou ajustar a decisão judicial, caso as características dos sites desindexados venham a mudar ${ }^{38}$.

\subsection{Sobre a repercussão e o cumprimento da decisão proferida no caso Google vs. Mario Costeja González}

A decisão proferida pela Corte de Justiça da União Europeia no caso Mario Costeja González recebeu ampla divulgação no Brasil e no mundo, repercutindo em várias jurisdições, para além daquelas submetidas à competência do referido tribunal.

A revista Veja, por exemplo, destacou que "[o] direito de ser esquecido só vale para versões europeias dos sites. Quem acessa o Google brasileiro não vê diferença ${ }^{39}$. Fora da Europa, porém, há quem o cite em processos contra sites" (VILICIC e ALLEGRETTI, 2014). A reportagem informa que nos Estados Unidos as ações não estariam sendo aceitas por conflitarem com a Primeira Emenda da Constituição Federal norte-americana (que impede a limitação ao direito à liberdade de expressão e de imprensa) e que, por outro lado, na Argentina, já estariam tramitando cerca de 130 pedidos de remoção de links na Justiça. A própria revista afirma ser alvo (juntamente com o Google) de ação judicial que aborda o direito de ser esquecido em sua fundamentação.

\footnotetext{
${ }^{38}$ Equustek Solutions Inc. v. Google Inc., 2015 BCCA 265 (CanLII), julgado em 11/06/2015.

${ }^{39}$ Com efeito, em acesso ao Google no Brasil (google.com.br) no dia 23 de novembro de 2015, com os termos Mario Costeja González La Vanguardia, o primeiro resultado da lista que surge é justamente o link com a reprodução em $p d f$ da página 23 da edição do dia 19 de janeiro de 1998 do jornal La Vanguardia, que contém o debatido informe sobre a venda de bens. Segue o link: http://hemeroteca.lavanguardia.com/preview/1998/01/19/pagina-23/33842001/pdf.html. Interessante é que, já numa busca somente pelo nome de Mario Costeja González, efetuada logo após a primeira pesquisa, a lista de resultados apresenta uma série de notícias sobre o caso judicial em si e sobre o direito ao esquecimento. $\mathrm{O}$ mesmo link para o jornal La Vanguardia também aparece, porém somente na página quatro da lista de resultados. Já há, todavia, no âmbito da Europa, questionamentos de autoridades e entidades de proteção de dados acerca da efetividade do entendimento de que a decisão teria efeitos apenas nos países da União Europeia.
} 
Acerca do contexto norte-americano, Toobin (2014) relata que o chamado direito ao esquecimento não existe nos Estados Unidos - país em que, ao contrário da Europa, a liberdade de expressão triunfaria sobre o direito à privacidade. De acordo com ele, a consideração pela liberdade de expressão, refletida na Primeira Emenda, garante que um caso como o de Mario González nunca estaria à altura das exigências do direito norte-americano. Diante de tal cenário, alguns indivíduos e mesmo empresas lesadas estariam recorrendo ao discurso dos direitos autorais para tentar diminuir a atenção na internet. Dada a proibição de se publicar fotos ou outros materiais sem a permissão dos respectivos detentores dos direitos autorais, tanto o Google como várias páginas ou sites da internet estariam acatando as solicitações e removendo os links ou os materiais sem maiores problemas. Já de longa data o Google teria, aliás, um sistema para impedir que material protegido por direitos autorais venha à tona nos resultados de suas buscas. Isso não garante que o conteúdo desapareça por completo, mas certamente torna-o mais difícil de ser encontrado. $\mathrm{O}$ que chama a atenção, neste ponto, é a possibilidade mesmo de se ter soluções distintas para uma mesma situação concreta (por exemplo, publicação de fotos picantes), conforme seja mobilizado o direito autoral ou o direito à privacidade.

Toobin (2014) descreve ainda como o Google teria se estruturado internamente para cumprir a decisão do Tribunal de Justiça Europeu que reconhecera o direito ao esquecimento na internet. Segundo ele relata, a primeira medida, de ordem técnica, teria sido a criação de uma infraestrutura de software que viabilizasse a remoção dos links. Isso não teria sido particularmente difícil, dada a prévia existência de sistemas com objetivos semelhantes, voltados à remoção de conteúdos protegidos por direitos autorais e marcas registradas e mesmo para bloqueio de links perigosos ou ilegais, como pornografia infantil. A segunda medida teria sido a mais trabalhosa, pois envolvera a criação de todo um sistema administrativo de admissão e análise das solicitações. Criou-se uma interface nas páginas de pesquisa locais do Google em cada país da União Europeia coberto pela decisão, a partir da qual cada interessado pode fazer sua solicitação mediante identificação de seu nome (pedidos anônimos não são possíveis), fornecimento e identificação dos links objetados (que podem referir-se a URLs com materiais de textos, imagens ou vídeos), além de esclarecimentos acerca dos motivos pelos quais a inclusão de tais links nos resultados de pesquisas seria irrelevante, desatualizada ou passível de objeção. Se o pedido é deferido, o Google envia um comunicado ao editor (webmaster) do site ou página da internet que hospeda ou contém o 
URL a que o link se refere - uma medida criticada por agentes reguladores europeus, dado o encorajamento que proporciona no sentido da republicação dos materiais deletados ${ }^{40}$. Conforme esclarece o Google na seção de perguntas frequentes sobre o cumprimento da decisão do Tribunal de Justiça Europeu, constante de seu Relatório de Transparência ${ }^{41}$, os webmasters são informados da remoção de URLs de seus sites com o intuito de aumentar a transparência. Em respeito à privacidade, a comunicação, contudo, informa quais URLs foram afetados, mas não o nome dos solicitantes. O Google informa ainda que os URLs são removidos somente de resultados de buscas feitas com o nome da pessoa. Logo, eles continuarão aparecendo em listagens de resultados caso a pesquisa seja feita por meio de outros critérios de busca que igualmente terminem por indicar o link para o mesmo URL.

De acordo com os esclarecimentos fornecidos pelo Google a Toobin (2014), as decisões nos casos concretos individuais não têm sido publicadas ou disponibilizadas. De qualquer forma, os casos estariam sendo examinados, analisados e discutidos por um grupo de especialistas (advogados, dentre outros), arregimentados para tanto, com a preocupação de manter decisões segundo padrões consistentes, partindo de critérios tais como o caráter público ou privado da pessoa envolvida e o papel por ela desempenhado na vida pública; se o link advém de reputada fonte de notícias ou de sites governamentais; se foi o próprio indivíduo que fez a publicação original da informação; e se a informação se relaciona com discursos políticos ou acusações criminais.

\footnotetext{
${ }^{40} \mathrm{Na}$ prática, já existem problemas nesse sentido. Conforme aponta Moody (2015), o ICO - Information Comissioner's Office, autoridade independente do Reino Unido responsável, dentre outras atribuições, pela defesa da privacidade de dados dos indivíduos, determinou que o Google removesse nove links de resultados de pesquisa que estavam apontando para notícias que davam conta de anterior decisão do Google que determinara a remoção de links que se referiam a uma infração criminal. Os novos links objetados direcionavam para artigos que, ao abordarem a anterior medida de desindexação adotada pelo Google, repetiam detalhes da infração criminal original - detalhes estes que estavam incluídos nos resultados originais então mostrados quando se procurava pelo nome da pessoa interessada e que teriam motivado a desindexação. Trata-se, como se pode perceber, de um problema de recursividade que pode ser levado a extremos. Outro ponto destacado por Moody (2015) diz respeito ao status de páginas de internet que as organizações de mídia estão criando para listar as matérias que têm sido removidas dos resultados de busca do Google. A título de exemplo, podem ser citadas a página do jornal The Telegraph (http://www.telegraph.co.uk/technology/google/11036257/Telegraph-storiesaffected-by-EU-right-to-be-forgotten.html) e página semelhante da BBC (http://www.bbc.co.uk/blogs/internet/entries/1d765aa8-600b-4f32-b110-d02fbf7fd379).

41 GOOGLE. Google transparency report. Disponível em: $<$ https://www.google.com/transparencyreport/?hl=pt-BR>. Acesso em: 01 ${ }^{\mathrm{o}} \mathrm{dez} .2015$.
} 
Em consulta ao Relatório de Transparência do Google é possível identificar que, em cumprimento à decisão do Tribunal de Justiça Europeu, desde 29 de maio de 2014 a empresa já teria recebido mais de 350.000 solicitações de remoção de links, tendo sido avaliados mais de 1.200.000 URLs. Do total de URLs já efetivamente processados, 42,1\% (444.576) teriam sido removidos e 57,9\% (612.089) não teriam sido removidos ${ }^{42}$.

Quanto ao âmbito dos efeitos da decisão, é de se noticiar questionamentos de autoridades e entidades de proteção de dados e privacidade acerca da limitação dos efeitos aos sites de pesquisa do Google dos países integrantes da União Europeia (por exemplo, google.fr, google.uk). Segundo eles, a decisão deveria aplicar-se mundialmente ao site google.com e às outras extensões não-europeias do Google ${ }^{43}$.

\footnotetext{
42 GOOGLE. Google transparency report. Disponível em: $<$ https://www.google.com/transparencyreport/?hl=pt-BR>. Acesso em: 01 ${ }^{\mathrm{o}} \mathrm{dez} .2015$.

${ }^{43}$ Para uma notícia de tal discussão na França, conferir: FRANÇA rejeita recurso do Google contra o "direito ao esquecimento". G1, 21 set. 2015. Disponível em: <http://g1.globo.com/tecnologia/noticia/2015/09/francarejeita-recurso-do-google-contra-o-direito-ao-esquecimento.html $>$. Acesso em: 03 dez. 2015.
} 


\section{CAPÍTULO 2 - BALIZANDO O DIREITO AO ESQUECIMENTO}

\subsection{Por que um direito ao esquecimento? Sobre tecnologia, memória e privacidade}

Por que se fala de um direito ao esquecimento? Por quais razões se coloca em evidência um direito a ser esquecido? Que condições histórico-sociológicas poderiam ser destacadas como propiciadoras da evidência, destaque ou mesmo aprimoramento de um discurso que busca garantir um direito de ser esquecido?

Não se está buscando, com tais perguntas, identificar determinações últimas para o surgimento do discurso do direito ao esquecimento, como se houvesse uma relação de causa e efeito a desencadear necessariamente o seu desenvolvimento - afinal, "não existe a segurança natural de que eles [os efeitos] se realizem, ou que para obter certos efeitos se possam combinar determinadas causas", sendo, ademais, sempre possível "buscar mais causas das causas, e mais efeitos dos efeitos" (LUHMANN, 2011, p. 104).

\footnotetext{
A causalidade, portanto, é sempre uma seleção que se deve atribuir a um observador com determinados interesses, com um tipo específico de estrutura de observação, e com uma capacidade bastante determinada de processar informação (LUHMANN, 2011, p. 105).
}

Pretende-se, portanto, neste momento, jogar luzes sobre determinados aspectos histórico-sociais cujo desenrolar no tempo veio a criar condições propícias à emergência de um discurso do direito ao esquecimento. A ausência de vinculação determinista entre tais fatores histórico-sociais poderá ser evidenciada, ainda, conforme adiante se verá, pela existência mesmo de várias soluções surgidas e propostas para enfrentar um mesmo problema, qual seja, os efeitos negativos (bem descritos nos casos já acima detalhados) decorrentes de uma sociedade que tudo registra e nada esquece.

Tomando como fio condutor de sua análise desenvolvimentos (técnicos) que alteraram a economia da lembrança e do esquecimento, Mayer-Schönberger (2009) sustenta ter havido uma mudança monumental de padrão na sociedade, no sentido de que o esquecimento teria deixado de ser a "regra" para se tornar a exceção, tendo sido substituído justamente pelo que seria o atual padrão, qual seja, a lembrança total. 
Sua análise parte da caracterização da memória humana, do surgimento da linguagem, da escrita e chega até aos dias digitais atuais.

Nesse percurso, a linguagem apresenta-se como um ganho poderoso, que possibilita o espalhamento dos conhecimentos e das experiências, bem como a preservação da memória de uma geração à outra, sem a necessidade de uma vivência, treinamento, participação ou engajamento presencial de indivíduos numa - como diz Luhmann (2007, p. 158), mencionando George Herbert Mead - sequência (ou conversação) recursiva de gestos que demandaria perceber e ser percebido simultaneamente. Com a linguagem, prossegue Mayer-Schönberger (2009, p. 24 e ss), há uma mudança na relação com o tempo que possibilita a identificação e lembrança de gerações anteriores e, com isso, a construção e o desenvolvimento a partir do conhecimento dos antepassados. A linguagem propiciou, ainda, a procura por pensamentos abstratos e o desenvolvimento de ideias acerca da vida e da natureza. O tempo próprio da comunicação trazido com a linguagem, que rompe com a simultaneidade do perceber e do ser percebido, ensejou mesmo a possibilidade de se dizer algo que nunca tenha sido dito (LUHMANN, 2007, p. 165).

A despeito desses desenvolvimentos da linguagem, Mayer-Schönberger (2009, p. 26 e ss) aponta ser custosa a passagem da memória por entre gerações por meio da oralidade. Lembrar, neste contexto, é algo que demanda tempo e esforço. Faz-se necessária a presença física ou conjunta de idosos e jovens; as estórias devem ser contadas várias vezes para que sejam assimiladas; requer-se atenção de contadores e ouvintes. Como destaca Luhmann, "quando predomina a tradição oral (essencialmente no ensino) não se pode renunciar à memória psíquica" (2007, p. 210, tradução nossa). De outro lado, embora todo esforço possível seja empregado para que algo seja assimilado e lembrado, a rememoração é sempre um processo (re)construtivo que depende de preferências e necessidades do presente. A memória humana não funciona como um dispositivo de armazenamento mecânico que possibilita o simples resgate de qualquer coisa estocada.

[A] memória dos sistemas psíquicos - assim como também a dos sistemas sociais não pode ser considerada simplesmente como uma espécie de armazenamento e disponibilidade mantida de estados ou acontecimentos passados. O passado é (e segue sendo) algo que não está operativamente disponível. Também a memória pode ser utilizada unicamente em operações cada vez atuais, é dizer, só no presente. Por isso a verdadeira função da memória não consiste em guardar o passado, senão em 
regular a relação entre lembrar e esquecer (LUHMANN, 2007, p. 209, tradução nossa $)^{44}$.

Depender apenas da comunicação oral - que encontra-se atrelada ao espaço e dependente da presença - traz consequências bastante amplas para a estruturação social e limita as possibilidades de conservar e lembrar (LUHMANN, 2007, p. 193 e ss). Tal estado de coisas muda sobremaneira (embora paulatinamente) quando do advento da escrita. "A escrita aumenta em primeiro lugar a quantidade de distinções que uma sociedade pode utilizar - armazenar, lembrar. Disso resulta, assim mesmo, um aumento das coisas ou aspectos do mundo que podem ser indicados" (LUHMANN, 2007, p. 196, tradução nossa).

A escrita - que funciona ainda como apoio externo da memória humana - permite que a comunicação venha a alcançar aqueles que estão ausentes no tempo e no espaço. A mudança de temporalidade ocorrida possibilita "a ilusão de simultaneidade do não simultâneo", ou seja, permite-se, em cada presente, a combinação de distintos presentes - os quais são, entre si, ou futuros ou passados. Aquilo que era futuro quando da escrita de um texto pode ser já passado quando se lê. Esse desacoplamento espacial e temporal entre o ato de comunicar (dar a conhecer) e o entendimento traz, como consequências mais diretas, tanto a abdicação da facilidade de esquecer quanto uma ampliação do raio de possibilidades de reordenação de enlaces ou sequências comunicativas em momentos posteriores não previsíveis (LUHMANN, 2007, p. 205-206). Nesta última situação, a escrita aumenta o risco de enganos (próprios ou não), bem como o risco de rejeição das comunicações.

A mudança na relação entre esquecimento e lembrança fica evidenciada também no fato de que, com a escrita, esquecer e lembrar torna-se uma questão de decisão. "Porque deixar algo por escrito é sempre também não escrever outra coisa. A escrita é memória feita por si mesma. Agora pode-se relembrar e esquecer mais do que anteriormente. (...) Impedir o esquecimento é um processo que acelera a aprendizagem” (LUHMANN, 2007, p. 210, tradução nossa). Doutro lado, deve-se ter em mente que tais mudanças fazem com que o passado, tanto como história escrita como também enquanto texto atualmente disponível, adquire um poder sobre o presente antes desconhecido.

\footnotetext{
${ }^{44}$ E como destaca Mayer-Schönberger (2009, p. 114-115), lembra-se melhor do que é lembrado com frequência, sendo que relembrar em si já torna mais provável recobrar no futuro o que foi lembrado. Por outro lado, o que é menos lembrado esvai-se mais rapidamente, a ponto de tornar-se difícil sua recordação.
} 
A despeito de todas essas mudanças, o advento da escrita, segundo MayerSchönberger (2009, p. 32 e ss), não teria alterado o fato de que relembrar se afigurava algo custoso - e que, por padrão, as pessoas continuaram a esquecer. Por envolver um trabalho de escrita/cópia, sempre haveria a possibilidade de erros. Os livros, feitos à mão, eram caros e assim permaneceram por muito tempo. Os melhores escribas não poderiam copiar mais do que poucas dúzias de livros ao longo da vida. Outrossim, ele destaca que, nas antigas Grécia e Roma, os escribas eram profissionais disputados, cujo trabalho requeria treinamento especializado custoso, que demandava tempo e estava fora do alcance da maioria das pessoas. Ademais, do meio para o final do primeiro milênio, relembrar tornou-se algo ainda mais caro para a maioria das pessoas, em virtude do controle que a Igreja Católica passou a exercer sobre os livros que poderiam ser copiados e lidos - e sobre quem poderia lê-los.

Fatores histórico-sociais associados à criação e desenvolvimento da impressão por tipos móveis levaram a uma imensa difusão da escrita, a uma produção em massa de livros e a novas mudanças sociais.

Com o avanço da impressão, não somente a bíblia como também vários outros textos puderam ser publicados e difundidos. Pelo menos na Europa, a Igreja perde paulatinamente a autoridade sobre o que deveria ou não ser publicado e lido, de forma que tal tipo de decisão deixa de se submeter a um critério unicamente religioso para ser algo determinado pelo mercado - que passa a imprimir e vender tudo que se apresenta possível. Com um preço mais baixo, um mercado de livros pôde se estabelecer e com ele uma demanda que pressupõe leitores e, portanto, o próprio desenvolvimento da leitura. Com a impressão e difusão torna-se possível analisar, separar, comparar os materiais existentes, identificando erros, confusões e contradições que demandam revisão, sistematização, simplificações e novas visões de conjunto. O saber reproduzido pela impressão estimula o acréscimo e a melhora do saber então existente (LUHMANN, 2007, p. 225-229).

Há também alterações na orientação temporal. Tornadas visíveis e difundidas contradições históricas em torno de determinadas tradições - as quais passam a ser localizadas no tempo devidamente datado -, os mitos fundadores caem e as próprias tradições que legitimavam as aristocracias se enfraquecem e passam a ser encaradas como opções ideológicas fadadas a se justificarem perante o fluxo do tempo (LUHMANN, 2007, p. 231). Ainda que somente mais de duzentos anos depois do surgimento da impressão, o lançamento 
de livros faz-se visível como "infraestrutura técnica para a manutenção e continuação de uma memória da sociedade, independentemente do que os indivíduos relembram de maneira mais ou menos casual e do que morre com eles" (LUHMANN, 2007, p. 232, tradução nossa). Para tanto são criadas bibliotecas públicas. Obtém-se uma estabilidade que independe da mudança geracional e que pode se renovar e figurar aberta a um futuro não determinado pelos indivíduos.

É precisamente a fundação técnica desta forma de distribuir e de conservar o saber que torna possível seu desacoplamento das formas de diferenciação social já estabelecidas, ficando o seu uso e como, desta maneira, à disposição dos sistemas funcionais (LUHMANN, 2007, p. 232, tradução nossa).

Embora a memória externa tenha ganhado produção em massa, relembrar, segundo Mayer-Schönberger, continuou como algo caro, de forma que o uso dos livros para ampliar a memória permaneceu ilusório para a maioria das pessoas ${ }^{45}$. Ele destaca o custo do papel - que se manteve caro por séculos - como um empecilho relevante para o fato dos preços não terem baixado muito. Tal custo veio a cair apenas no início do Século XIX, em virtude do avanço da Revolução Industrial e com as mudanças na impressão e nas fábricas daí decorrentes. Com a diminuição do preço do papel e a elevação de sua produção, a publicação de livros cresceu como nunca antes, fazendo a memória externa aumentar. Contudo, o número de pessoas que compravam livros e liam não foi grande nas décadas iniciais do Século XIX, devido a fatores ligados à não-alfabetização e ainda aos custos de leitura - seja pelo preço dos livros, ainda caro, seja pelas parcas condições empíricas de acesso que os trabalhadores de então dispunham. Algo semelhante ocorreu com os periódicos. Embora já fossem uma realidade desde pelo menos o Século XVI, eles só se tornaram um fenômeno de massa na Europa com a alfabetização e com o surgimento dos papeis baratos para impressão (MAYERSCHÖNBERGER, 2009, p. 39 e ss).

Toda essa impressão, produção e leitura em massa de livros e jornais ou periódicos, juntamente com o surgimento do rádio e da televisão, propiciou uma ampliação cada vez maior da memória social e da construção de um entendimento comum sobre o mundo. Todavia, estando a demanda altamente concentrada num número limitado de fontes de impressão e transmissão (somente um jornal, um canal de televisão), termina por ocorrer

\footnotetext{
${ }^{45}$ Mayer-Schönberger destaca que isso não foi diferente em realidades fora da Europa, embora em virtude de razões diversas.
} 
uma limitação no quantitativo de informações que forma a base de tal memória. $\mathrm{O}$ resultado disso é que, com exceção daqueles poucos eventos reportados, para a maioria dos eventos a lembrança permaneceu como exceção e o esquecimento como regra. Isso não mudou significativamente nem com a chegada de dispositivos eletrônicos (analógicos) de fotografia, gravação e filmagem - todos inicialmente muito caros. E mesmo com o progressivo barateamento de tais dispositivos e das respectivas mídias de armazenamento/memória (estas, com capacidades cada vez maiores), muito tempo ainda se perdia, seja para armazenar os dados, seja para resgatá-los. Basta imaginar a necessidade de separar e catalogar fotos, identificar cada fita cassete, rebobinar ou adiantar horas de gravações para localizar determinado ponto desejado etc. A quantidade possível de informações a serem capturadas e armazenadas sem dúvida cresceu. Fundamentalmente, contudo, relembrar ainda permanecia como algo um pouco mais complexo e difícil do que esquecer, de forma que de regra se procurava registrar e lembrar aquilo que era mais importante e que justificava o esforço extra, esquecendo-se de todo o resto (MAYER-SCHÖNBERGER, 2009, p. 44 e ss).

Algumas mudanças tecnológicas posteriores, desenvolvidas ao longo do Século XX (e mesmo ainda em curso) possibilitaram uma alteração profunda em termos de custos, quantidade e forma de resgate ou recuperação de dados/informações, a ponto de MayerSchönberger defender mesmo o fim do esquecimento (the demise of forgetting). Ele destaca quatro principais avanços tecnológicos que facilitaram tal mudança: a digitização (digitization) $)^{46}$, o armazenamento barato (cheap storage); a recuperação fácil (easy retrieval) e o alcance global (global reach) (MAYER-SCHÖNBERGER, 2009, capítulo III). A seguir são destacados os principais aspectos de cada um deles.

Quando uma informação é analogicamente armazenada, ela tende a agregar variações aleatórias (“ruídos”) à medida em que é sucessivamente processada, armazenada, transmitida, copiada. Cópias das cópias sucessivamente extraídas tenderão a agregar ruídos que desnaturam e modificam a fidelidade ao original. Nesse processo, o próprio original pode sofrer modificações, ainda que menores. No mundo analógico, ademais, há uma especificação de equipamentos (com os correlatos mercados que lhe são necessários), cada qual voltado ao processamento, armazenamento e resgate de um tipo de informação (textos, músicas, vídeos

\footnotetext{
${ }^{46}$ De uma maneira geral, trata-se de um processo por meio do qual dados (sons, imagens, textos etc.) são "convertidos em sequências numéricas ou de dígitos - de onde digital - interpretados por um processador capaz de realizar cálculos de extrema complexidade em frações de segundo, o computador" (MARTINO, 2015, p. 11, grifo do original).
} 
etc.). No paradigma digital, isso muda. Uma cópia de uma informação digital apresenta-se como uma réplica do original, com a vantagem de não se desnaturar ou perder qualidade ao longo de sucessivas cópias, reproduções ou resgates. Por outro lado, a forma como a informação digital é produzida permite que um mesmo dispositivo geral armazene e processe diferentes tipos de informação digital - ou seja, independentemente de se tratar de sons, vídeos ou textos. É o caso, por exemplo, dos computadores pessoais. Essa estandardização apresenta reflexos também na redução dos custos em geral e na própria facilidade de compartilhamento e distribuição das informações (MAYER-SCHÖNBERGER, 2009, p. 52 e ss).

Os custos de armazenamento de informações, por sua vez, caíram consideravelmente ao longo dos anos, inicialmente tanto no formato analógico, quanto posteriormente no formato digital (que superou o analógico), a ponto de se permitir uma produção em massa e um uso individual, personalizado e igualmente massificado. Paralelamente à diminuição dos custos, de sua sorte, a capacidade de armazenamento cresceu enormemente.

$[O]$ armazenamento digital ficou tão barato que guardar informação - mesmo fullscreen vídeos - em memória digital [tornou-se] mais barato do que [n]os correspondentes analógicos de armazenamento de informação (papel, película, fita). Ele torna possível preservar a quantidade tremenda de informação que nós encontramos e geramos.

$(\ldots)$

Essa superabundância de capacidade de armazenamento disponível torna fácil para nós mudar nosso padrão comportamental com relação à memória externa do esquecimento para a lembrança (MAYER-SCHÖNBERGER, 2009, p. 67-68, tradução nossa).

Em tal contexto, se os custos de armazenamento são mínimos, ou mesmo inexistentes, Mayer-Schönberger (2009, p. 68 e ss) aponta não haver razão ou incentivo, economicamente falando, para ter de decidir entre lembrar ou esquecer. Torna-se mais conveniente deixar tudo armazenado, com a presunção de que algum dia o material pode vir a ser utilizado - o que significa, na prática, que (decidir) esquecer tornou-se algo custoso para as pessoas. Esse barateamento dos custos teria contribuído, ainda, para o surgimento de empresas como o Google, que além de prover serviços de e-mail com armazenagem ilimitada 
e de graça, possui uma capacidade gigantesca de estocagem de dados, oriundos seja das páginas da internet que indexa, seja dos critérios ou das buscas feitas pelos usuários (e do comportamento desses).

Juntamente com o barateamento dos custos de armazenamento, MayerSchönberger (2009, p. 72 e ss) prossegue destacando a facilidade no resgate ou na recuperação dos dados - algo que se fez presente com a paulatina superação do paradigma analógico pelo digital.

Segundo ele, mesmo com todos os desenvolvimentos em torno de livros, arquivos e bibliotecas, que propiciaram o surgimento da paginação, de índices, da indexação, dos critérios de agrupamento e arquivamento e de outras ferramentas para recuperação da informação, sua exata localização continuou a ser complexa, a demandar organização e manutenção meticulosas. Apresentando-se de forma sequencial e inflexível, o armazenamento analógico trazia custos de tempo e de esforço para a recuperação dos dados, sendo necessário muitas vezes ir de página em página (ou mesmo ler um livro todo) para achar o que se estava procurando.

O advento do armazenamento digital teria, assim, tornado mais fácil a recuperação da informação, ao possibilitar o desenvolvimento de ferramentas de localização a partir de pesquisas dentro dos próprios arquivos, de forma, portanto, não sequencial e segundo critérios flexíveis, não pré-definidos. Haveria, portanto, hoje, uma convergência mesmo de critérios de busca, os quais abarcam vários níveis - desde a localização de um documento em si até a busca dentro dele.

Todas essas mudanças adquirem alcance global com o desenvolvimento de redes digitais mundiais, como a internet, as quais permitem o acesso a bases de dados digitais localizadas em qualquer parte do globo, desde que haja não uma presença física do interessado perante a base (tornada desnecessária), mas apenas as respectivas conexões dele e da base de dados à rede de comunicação. Trata-se de uma mudança que altera fundamentalmente (para baixo) os custos de busca e resgate de informações e que, juntamente com os demais avanços acima relatados, permite que a informação permaneça disponível, alcançável remotamente e sujeita a vários usos - inclusive ativamente criativos, como a possibilidade mesmo de formação de novos materiais (por parte de qualquer pessoa) a partir 
do corte, adição, recombinação, enfim, edição de informações de terceiros disponíveis na rede (MAYER-SCHÖNBERGER, 2009, p. 79 e ss).

Conforme aponta Luhmann, "[o] que realmente se observa são redes de interconexão que operam mundialmente para compilar, avaliar e fazer novamente disponíveis dados", e que servem como mais um argumento para demonstrar "o fato de uma sociedade mundial que intensifica e acelera as comunicações de tal maneira que sem esses novos meios de difusão não seria possível" (LUHMANN, 2007, p. 236, tradução nossa). Ademais, pode-se reconhecer que todas essas modificações técnicas apresentam-se como novas formas de distribuir e de conservar o saber que, à semelhança do que ocorreu com a impressão dos livros, colocam-se à disposição para uso dos sistemas funcionais (sobretudo para uso dos meios de comunicação de massa), abrindo-se, pois, a oportunidades variadas de aproveitamento.

Tecnicamente induzidas, e logo delimitadas pela utilização e por dinâmica própria, as possibilidades de comunicação ampliam-se substancialmente em plano mundial (o mundo todo torna-se comunicável), tornando mais aguda a discrepância entre comunicação possível e comunicação que atualmente ou de fato tem lugar. E, admitindo-se a possibilidade de identificação de tendências nesse processo evolutivo dos meios de difusão, pode-se apontar a passagem de uma ordem comunicacional hierárquica para uma ordem comunicacional heterárquica e a renúncia a uma integração espacial das operações da sociedade (LUHMANN, 2007, p. 234 e ss).

Atuando de forma alternativa às comunicações hierárquicas - as quais, pressupunha-se, podiam se impor sobre os estratos inferiores da pirâmide social - os meios de difusão abriram paulatinamente espaço para as comunicações horizontais na sociedade e para o que se denomina de "opinião pública". Neste contexto, a tecnologia computacional deu, inclusive, um passo mais adiante, a ponto de avançar mesmo sobre a autoridade dos experts ou especialistas. "Num futuro não tão distante ${ }^{47}$, qualquer um terá em princípio a possibilidade de ratificar em seu próprio computador as afirmações de médicos ou juristas peritos" (LUHMANN, 2007, p. 242, tradução nossa). Provas científicas da eficácia de medicamentos, tidas por inexistentes, poderiam ser encontradas por meio do computador,

\footnotetext{
${ }^{47}$ A primeira edição em alemão da obra de Luhmann intitulada Die Gesellschaft der Gesellschaft data de 1997. Aqui, utilizamos a versão em espanhol (La sociedad de la sociedad), cuja tradução é do ano de 2007.
} 
assim como também jurisprudências para certos problemas jurídicos sem precedentes. Como o processamento eletrônico não pode ser personalizado na figura de um expert, também a confiança que nele se deposita também não é personalizada - é tão somente confiança sistêmica (LUHMANN, 2007, p. 243). Quando se pensa em motores de busca como o Google (o Dr. Google, ironicamente chamado pelos médicos), percebe-se que o futuro a que Luhmann se referia já chegou. E que a confiança em tais mecanismos eletrônicos de processamento ou tratamento de informações, integrantes do sistema dos meios de comunicação de massa, não é personalizada (ou depositada numa pessoa, num expert), mas decorre simplesmente da confiança no sistema em si.

Já com a renúncia a uma integração espacial das operações da sociedade, crescem os graus de liberdade dos sistemas (e, assim, dos meios de massa), ou seja, o número de possibilidades que podem realizar cresce à medida que há uma independência cada vez maior com relação a lugares e a condições locais concretas. Uma circunstância que tem a ver com a própria emergência de uma opinião pública - já que por "público" se deve pressupor justamente "deixar livre a entrada a qualquer pessoa (renúncia ao controle de acesso), ou seja, indeterminação estrutural da integração espacial" (LUHMANN, 2007, p. 244, tradução nossa).

Todas essas modificações (tecnológicas) terminam por se refletir, assim, em maior ou menor grau, em várias áreas da sociedade. Uma memória digital ampla pode ser benéfica (e certamente o é, em vários sentidos - como, por exemplo, em termos de eficiência), mas também pode trazer consequências indesejadas ou danosas. O que está em jogo e quais são os impactos? Mayer-Schönberger (2009, capítulo IV) analisa tais questões sob duas diretrizes: o poder e o tempo.

Sob o prisma do poder (MAYER-SCHÖNBERGER, 2009, p. 97 e ss), testemunhar-se-ia uma erosão ou perda contínua de controle dos indivíduos sobre suas informações pessoais, acompanhada de um correspondente ganho de poder informacional por parte de outros agentes capaz de alterar a sociedade e influenciar nossas futuras interações com o mundo. Antigamente, se alguém perdesse o controle de suas informações, poderia, em última instância mesmo, ainda que sob custos maiores, mudar de vizinhança, bairro, cidade ou mesmo país e se livrar de seu passado (já que as informações permaneciam locais), começando uma nova vida. Com as mudanças ocorridas e a redistribuição (desigual) do poder 
informacional - catalisado pela acessibilidade fácil às informações, pela durabilidade dessas e pela sua ampla abrangência ${ }^{48}$ - deixar o passado para trás ficou muito mais difícil. A pessoa pode até ter esquecido, mas os outros não esqueceram o passado dela - e podem "acessá-lo" e "usá-lo" das formas mais variadas, inclusive mediante a compilação de ocorrências e dados de diferentes fontes. Se, conforme funciona a memória, o ser humano encontra-se constantemente (re)construindo suas lembranças, de acordo com suas necessidades e com quem ele é no presente, e se a memória digital possui amplo alcance e extensão (comprehensiveness), sendo facilmente armazenável, recuperável, durável, compilável e apta a todo tipo de tratamento e uso por terceiros, segundo as mais variadas finalidades - mas, de toda forma, constante e congelada no tempo -, certamente haverá um choque entre as duas apto a restringir a liberdade do indivíduo em forjar seu próprio passado e sua identidade no presente. Tal realidade terminaria, assim, por favorecer mesmo um clima de autocensura (afinal, tudo pode ser usado contra a pessoa), capaz de minar debates, opiniões abertas e outros comportamentos.

Mayer-Schönberger (2009, p. 112 e ss) prossegue para destacar, agora, que a lembrança digital negaria o tempo e ameaçaria a habilidade de decidir racionalmente, aumentando a vulnerabilidade das pessoas à indecisão ou a julgamentos incorretos. Prejudicaria, pois, a capacidade humana de act in time - de agir a tempo e no tempo. $\mathrm{O}$ esquecimento, aqui, funcionaria como uma condição para deixar de lado certas diferenças e particularidades em prol da possibilidade da produção de generalizações, conceituações e abstrações que permitem tomar decisões e agir. Trata-se de situação que evoca a condição de Ireneo Funes, personagem de Borges (2007), que, após ter sofrido um acidente, torna-se não somente paralítico como também detentor de uma extraordinária e infalível memória, capaz de fazer o presente e o passado (“as memórias mais antigas e mais triviais”) quase intoleráveis de tão ricos e nítidos. Suas lembranças, porém, não eram simples, já que cada imagem visual recordada se fazia acompanhar de sensações (“musculares, térmicas etc.”). Seu vertiginoso, multiforme, preciso e instantâneo mundo praticamente o incapacitava para a formulação de ideias gerais. Era-lhe custoso compreender, por exemplo, que o nome genérico "cachorro"

\footnotetext{
${ }^{48}$ É de Doneda a observação de que "[s]em perder de vista que o controle sobre a informação foi sempre um elemento essencial na definição de poderes dentro de uma sociedade, a tecnologia proporcionou a intensificação dos fluxos de informação e, consequentemente, a multiplicação de suas fontes e de seus destinatários. Esta mudança, a princípio quantitativa, acaba por influir qualitativamente, mudando os eixos de equilíbrio na equação poder - informação - pessoa - controle. Isto implica que devemos tentar conhecer a nova estrutura de poder vinculada a esta nova arquitetura informacional" (DONEDA, 2006, p. 15-16).
} 
pudesse retratar tantos indivíduos, de diferentes tamanhos e formas, e que um mesmo cachorro em si, visto num dado momento (“de perfil"), pudesse ter o mesmo nome quando visto (“de frente") logo em seguida, num momento ou instante posterior. Suspeitava-se, assim, da sua habilidade para pensar, já que "[p]ensar é esquecer diferenças, é generalizar, abstrair. No mundo entulhado de Funes não havia senão detalhes, quase imediatos" (BORGES, 2007) ${ }^{49}$.

O aspecto temporal destacado por Mayer-Schönberger também aponta para o fato de que, em contraposição à memória humana, uma ampla memória digital estaria exacerbando certos processos humanos, tornando mais difícil, por exemplo, colocar eventos passados numa perspectiva temporal apropriada ou mesmo aprender - algo que demanda certo esquecimento. Se, como disse Luhmann (2007, p. 210, tradução nossa), “[i]mpedir o esquecimento é um processo que acelera a aprendizagem", a perspectiva apresentada por Mayer-Schönberger parece sugerir que a dosagem do remédio está crescendo a ponto de já se tornar venenosa.

Uma memória digital, contudo, por mais ampla que seja, não contemplaria todos os aspectos do "objeto" (ou seria melhor falar sujeito?) buscado, havendo a possibilidade de omissões de fatos ou aspectos importantes não digitalizados. Quando se toma em consideração, todavia, os motores de busca e a facilidade e inegável amplitude com que permitem o resgate da memória armazenada, segundo Mayer-Schönberger (2009, p. 123-124), toda essa omissão terminaria por passar desapercebida ou simplesmente ignorada, assim como o próprio tempo das informações resgatadas nos resultados da busca: anos e mesmo décadas de uma vida são agrupados e congelados em links conjuntamente reunidos, numa colagem incompleta que não tem condições de refletir quem a pessoa retratada (atualmente) de fato é ou seja, qual a sua identidade.

\footnotetext{
${ }^{49}$ Uma capacidade enorme de recordar não parece estar limitada à realidade da ficção literária. Jill Price foi a primeira paciente a ser diagnosticada com uma "síndrome da hipermemória", que lhe permite recordar contínua e automaticamente lembranças autobiográficas de cada dia de sua vida desde seus quatorze anos. Sua memória não é e nem se fixa em detalhes extremos como a de Funes, o memorioso, mas ela reconhece que sua capacidade funciona, em muitos aspectos, tanto como uma benção, como uma maldição. De toda forma, como Funes, sua memória a faz não somente lembrar, mas igualmente sentir intensamente as emoções associadas, como se estivesse realmente revivendo o momento relembrado. Ela possui diários, nos quais figuram não reflexões, comentários ou interpretações sobre sua vida, mas apenas registros do dia - anotações que "mostram a falta de seletividade ou foco, típica de [sua] memória, em relação aos momentos mais importantes do dia. A notícia terrível do ataque ao World Trade Center vem misturada com os detalhes mais triviais" (PRICE e DAVIS, 2010, p. 115).
} 
Essas colagens digitais combinam inúmeros pedaços de informação sobre nós, cada um (quando muito) tendo sido válido num certo ponto de nosso passado. Mas da forma como eles são apresentados a nós, configuram informação da qual o tempo foi eliminado; uma colagem na qual a mudança apresenta-se visível apenas como uma tensão entre dois fatos contraditórios, não como um processo evolutivo, que se desenrola no tempo.

\section{(..)}

Da perspectiva da pessoa que relembra, a memória digital trava o julgamento. Da perspectiva da pessoa lembrada, contudo, ela nega o desenvolvimento e recusa o reconhecimento de que todos os seres humanos mudam o tempo todo ${ }^{50}$. Ao recordar para sempre cada um de nossos erros e transgressões, a memória digital rejeita nossa capacidade humana de aprender com eles, de crescer e de evoluir (MAYERSCHÖNBERGER, 2009, p. 124-125, tradução nossa).

Essa situação toda - que na prática exacerba algo que Luhmann já havia identificado com o advento da escrita, ou seja, a mistura de tempos num mesmo tempo presente ou a ilusão de simultaneidade do não simultâneo - termina por dar ensejo a que as pessoas fiquem para sempre presas aos seus passados, sem esquecimento, sem perdão e sem redenção. E isso parece estar bem evidenciado nas situações concretas que dão substrato aos casos judiciais discutidos no presente trabalho.

Muitas respostas apresentam-se possíveis para reagir ou para dar conta dos efeitos negativos decorrentes das mudanças que ensejaram "o fim do esquecimento". MayerSchönberger (2009, capítulos V e VI) traça um resumo de medidas já adotadas ou possíveis de serem desenvolvidas e implementadas (pelos indivíduos, pelo direito ou pela tecnologia) para, em seguida, trazer sua própria sugestão.

Como forma de "atacar" os efeitos negativos relacionados à questão do poder, ele aponta a abstinência digital (digital abstinence), os direitos de privacidade informacional (information privacy rights) e uma infraestrutura de direitos de privacidade digital (digital privacy rights infrastructure).

\footnotetext{
${ }^{50}$ Vide Wright (2015), para uma visão diferente, que chama a atenção para o valor da informação para aquele que pretende confiar num estranho e para o fato de que as pessoas podem até mudar, mas não em amplas magnitudes. Mais detalhes sobre Wright (2015) serão apresentados no tópico seguinte deste capítulo.
} 
A abstinência digital (MAYER-SCHÖNBERGER, 2009, p. 128-134) propõe uma mudança comportamental dos indivíduos no sentido de evitar ao máximo interações que ensejem a revelação de dados pessoais. Isso demandaria conscientização quanto aos perigos do mau uso das informações pessoais. De toda sorte, Mayer-Schönberger destaca que deixar de compartilhar informações talvez não fosse algo que as pessoas viessem a adotar (pelo menos na atualidade), por várias razões, dentre as quais o fato de que o compartilhamento de dados normalmente tem como contrapartida certos benefícios - como experiências customizadas, resultados de pesquisa mais refinados etc., além de propiciar uma interação apreciada e aproveitada sob vários aspectos.

Os direitos de privacidade informacional configuram um mecanismo aceito e viável (MAYER-SCHÖNBERGER, 2009, p. 134-144). Com eles, postula-se basicamente que os indivíduos sejam legalmente dotados do direito a manter um controle sobre suas informações, decidindo se, quando e para qual finalidade compartilhar suas informações. A seu respeito, Mayer-Schönberger (2009, p. 136 e ss) traça um paralelo geral entre a realidade estadunidense e europeia. Enquanto nos Estados Unidos tal privacidade cobriria apenas o processamento de informações por agências governamentais federais - inexistindo, portanto, um direito geral oponível a quaisquer outros corpos jurídicos -, na Europa ela compreenderia o direito dos indivíduos de se oporem a quaisquer processadores de informações, públicos ou privados $^{51}$. A privacidade europeia iria muito além da concepção trazida por Warren e Brandeis $(1890)^{52}$ e da ideia da necessidade de um consentimento individual, abarcando mesmo a possibilidade de discutir os propósitos e as condições do processamento das informações, de modo a abrir ao indivíduo espaço para moldar sua participação na sociedade ${ }^{53}$.

\footnotetext{
${ }^{51}$ Tendo a questão da privacidade como fundo, mas tratando já diretamente do direito ao esquecimento, Wright (2015) destaca que a jurisprudência e a legislação dos Estados Unidos, pelo menos na atualidade, não comportam um direito ao esquecimento genérico, amplo e profundo como o Europeu. Assim, o direito americano evitaria o estilo europeu expansivo de forjar grandiosas e amplas teorias, preferindo proteções sob a forma de vários direitos gradualmente acumulados, restritos, particularizados, que demandam contextualização e que se assemelham ou se aproximam apenas frouxamente ou de forma ampla. Tais proteções são acompanhadas de medidas legislativas específicas, voltadas para contextos particulares.

${ }^{52}$ Vide texto mais abaixo.

${ }^{53} \mathrm{O}$ assunto será abordado adiante com maiores detalhes.
} 
Apontando para uma necessidade de refinamento e simplificação na sua imposição (enforcement), alguns obstáculos ou pontos fracos nesse mecanismo jurídico do direito à privacidade podem ser destacados. Tendo a realidade estadunidense como luz, Mayer-Schönberger (2009, p. 138 e ss) identifica que a restrição ao poder de processar informações pode ofender direitos dos processadores, como a liberdade de expressão ou a liberdade econômica. De outro lado, há riscos e custos para sua efetividade, como, por exemplo, a necessidade da parte interessada ter de revelar-se ou de expor-se para fazer valer seu direito em juízo, bem como o tempo e o esforço despendido em tal empreitada. Interessante, aqui, é que o caso Mário Costeja González é bem exemplificativo. Ele de fato foi bastante exposto e ficou bem conhecido - mundialmente. O mesmo não se pode dizer, contudo, das pessoas que se beneficiaram de seu leading case. Elas podem até vir a serem expostas - uma vez que, como já apontado no presente trabalho, há sites listando os links excluídos -, mas certamente não na dimensão de Mario González. Com relação ao tempo e ao esforço, isso ficou bem relativizado com a desnecessidade de procurar o Judiciário, pelo menos no âmbito da União Europeia, relativamente ao Google. No Brasil, contudo, a necessidade de busca pelo Judiciário é uma realidade que, se de um lado traz garantias, de outro aponta também para a necessidade de debate quanto aos custos e à exposição. De toda sorte, seja aqui ou alhures, discussões quanto a custos e exposição permanecem de uma maneira geral, em se tratando de um direito à privacidade demandado em face de outras mídias, como a televisão.

Mayer-Schönberger (2009, p. 144-154) aventa também a possibilidade de se criar uma infraestrutura de direitos de privacidade digital, à semelhança do que já ocorre, por exemplo, com direitos de propriedade intelectual - os quais utilizam-se de tecnologias de gerenciamento de direitos digitais (digital rights management - DRM) para agregar metadados que delimitam quem pode usar os dados e como isso pode ocorrer. Um exemplo rudimentar é o dos DVDs, que vêm encriptados e vinculados a determinadas regiões geográficas, de forma a rodarem apenas com a chave de codificação correta ou no aparelho destinado à respectiva região. A ideia seria aplicar tais conceitos para criar um sistema capaz de controlar e fazer valer (enforce) esse controle sobre outros tipos de informação, como as informações pessoais. Mayer-Schönberger aponta vários desafios nessa solução, sendo de destacar as dificuldades, o custo e o tempo despendidos para detalhar as variadas condições, as finalidades, o preço, enfim, os usos possíveis; para manter tais políticas de uso atualizadas; 
para verificar sua observância ao longo do processamento; para fazer parar o mau uso; para evitar a quebra das codificações etc. Segundo ele, todas essas medidas, sob o ponto de vista dos direitos de propriedade intelectual, contam com grandes corporações para serem implementadas. Do ponto de vista das informações pessoais, elas ficariam, contudo, atomizadas nos indivíduos - uma incumbência difícil e custosa de desempenhar.

Já no tocante ao problema do tempo, Mayer-Schönberger (2009, p. 154-168) relaciona três possíveis respostas: o ajuste cognitivo (cognitive adjustment), uma ecologia das informações (information ecology) e uma contextualização perfeita (perfect contextualization).

O ajuste cognitivo (MAYER-SCHÖNBERGER, 2009, p. 154-157) considera que os efeitos negativos da persistência de memória podem perder força e ser domados mediante uma adaptação na maneira como os seres humanos encaram a presença permanente de informações, fazendo com que eles reconheçam a possibilidade de mudança constante e passem a simplesmente desconsiderar fatos passados em seus julgamentos e decisões. Haveria uma reformulação da maneira de pensar, avaliar e decidir. Mayer-Schönberger não descarta tal mudança na forma de se encarar o mundo, mas ele não acredita que isso possa ocorrer num curto horizonte temporal e nem que essa forma de adaptação possa ser deliberadamente acelerada. Tal resposta, portanto, não daria conta, segundo ele, dos problemas enfrentados na atualidade.

Com uma ecologia das informações (MAYER-SCHÖNBERGER, 2009, p. 157163), busca-se deliberadamente regular que tipos de informações podem ser coletadas, armazenadas e lembradas, quem pode fazê-lo e por quanto tempo. Trata-se de medida já adotada em várias situações, que depende de regras contextualmente direcionadas a determinados dados (os quais podem vir a ser deletados ou descartados ou apenas ter seu acesso restringido) e ao exaurimento da finalidade que determinou seu recolhimento e tratamento. Tais regras são encontráveis tanto em leis formais quanto em normatizações (guidelines) de companhias privadas. Mayer-Schönberger chama a atenção para a inflexibilidade dos limites temáticos e específicos de tais regras, deixando várias informações não tipificadas desprotegidas, ao mesmo tempo em que destaca a dificuldade política de tais regramentos irem adiante nos dias atuais (pelo menos no contexto norte-americano), em face de problemas causados pelo terrorismo após os atentados de 11 de setembro de 2001 - os 
quais trouxeram impactos determinantes para a necessidade de retenção de dados e para a valorização da correlação das informações na busca pela prevenção de crimes.

Já quanto à ideia de uma perfeita contextualização (MAYER-SCHÖNBERGER, 2009 , p. 163-167), a proposta volta-se à criação de uma infraestrutura técnica capaz de armazenar e permitir o resgate de uma quantidade muito maior de informações que as atualmente existentes. Com isso, busca-se aumentar a completude e amplitude do retrato do passado, propiciando sua devida contextualização e, assim, uma adequada e melhor tomada de decisões. A estrutura técnica partiria de um conceito de transparência geral, aproveitável igualmente por todos. Segundo Mayer-Schönberger, trata-se de uma medida problemática em vários sentidos. Além de dar ensejo à criação de uma sociedade da vigilância, em que uns dedurariam os outros, certamente alguém ou alguma entidade terminaria por desenvolver meios técnicos e organizacionais de controlar assimetricamente as informações, combinandoas e correlacionando-as e, assim, adquirindo poder sobre quem não poderia fazê-lo. De outro lado, por mais amplo que fosse em termos de armazenamento de comunicações, o sistema técnico não conseguiria captar os pensamentos humanos, apenas as informações externalizadas. Ademais, mesmo com uma incrível e exata fonte de informações mobilizada na tentativa de recriação do contexto de um evento passado, não haveria como voltar no tempo e acessá-lo em sua forma original. Por fim, as pessoas, seus interesses, suas visões, seus valores, seus conhecimentos, suas indagações etc. mudam com o passar do tempo, impedindo a repetição de uma experiência tal como ela uma vez já ocorreu. Enfim, como já destacado por Luhmann (2007, p. 209), o passado não se encontra operativamente disponível no presente.

Procurando avançar para além desse mar de possibilidades de reações ao império da memória digital, Mayer-Schönberger (2009, capítulo VI) sugere o estabelecimento de datas de expiração para as informações. Uma solução voltada, portanto, para revitalizar o esquecimento. Embora admita variações, a ideia básica é a da necessidade de especificação de uma data junto da informação armazenada, a partir da qual a informação seria deletada ou descartada automaticamente. Assim, por exemplo, numa forma simples, quando o usuário fosse salvar um documento que ele criou, ele teria necessariamente de indicar não somente o respectivo nome do arquivo, mas sua respectiva data de expiração. Ferramentas de aviso sobre documentos com datas próximas da expiração e que possibilitassem eventuais alterações poderiam ser igualmente desenvolvidas. Seria uma maneira, de acordo com o autor, de trazer 
para o primeiro plano de observação a finitude das informações, ou seja, seu caráter datado, vinculado a um determinado tempo e, portanto, sujeito à perda de valor informacional - à semelhança de um jornal do dia anterior ou de uma velha piada ouvida várias vezes (MAYER-SCHÖNBERGER, p. 171-172). Trata-se do desenvolvimento de um mecanismo técnico relativamente simples que teria a capacidade de fazer as pessoas pararem, ainda que brevemente, para refletir sobre o valor e a utilidade das informações, considerando sua temporalidade e vida útil.

Ademais, caracterizando-se como uma meta-informação aderida à informação, a cópia de um arquivo digital produziria automaticamente também a reprodução de sua respectiva data de expiração, com o objetivo, assim, de assegurar a extinção da informação na data originalmente determinada, mesmo para as cópias produzidas. Softwares ficariam encarregados de promover as limpezas regularmente. Para a implementação de algumas dessas medidas e a definição de seu alcance, o reforço de mecanismos legais se faria necessário (MAYER-SCHÖNBERGER, 2009, p. 174).

Com relação às atividades dos motores de busca, que atuam rastreando e indexando páginas da internet, Mayer-Schönberger entende que a solução proposta poderia ser aplicada de maneira mais produtiva do que aquela atualmente existente - que permite que um editor de um site ou página da internet adicione meta-informações que impeçam a indexação ou o armazenamento em cache de uma determinada página sua. Para além dessa solução binária (permitir a indexação/armazenamento ou não), a solução aventada possibilitaria que os editores analisassem a relevância de suas informações, indicando por quanto tempo os motores de busca poderiam apresentar o link para uma determinada página sua nos resultados de busca ou manter o respectivo conteúdo armazenado em cache. Os motores de busca poderiam mesmo até mostrar as datas de expiração ao lado dos respectivos resultados de busca, como forma de indicar o seu valor relativo (MAYER-SCHÖNBERBER, 2009, p. 179-180 $)^{54}$.

\footnotetext{
${ }^{54}$ A proposta aventada poderia também, segundo Mayer-Schönberger, ser utilizada para fixar datas a partir das quais os registros dos critérios de pesquisa dos usuários, armazenados pelos motores de busca, deveriam expirar e serem apagados. Os próprios usuários poderiam indicar tais datas quando da realização de uma pesquisa. Embora houvesse perda no quantitativo de informações, isso garantiria maior controle por parte dos usuários sobre seu histórico de buscas, além de propiciar dados qualitativamente melhores para os motores de busca (MAYER-SCHÖNBERGER, 2009, p. 180).
} 
De toda forma, o próprio autor admite que a solução das datas de expiração não funciona como o esquecimento humano, já que é, em si, binária: a informação está disponível, mas, após a expiração, não mais está, eis que deletada. Seria uma fraqueza estrutural da proposta, a ser suprimida, segundo ele, com aperfeiçoamentos a serem pensados e desenvolvidos com o intuito de mimetizar a graduação que o esquecimento humano carrega ${ }^{55}$.

Ele reconhece, ademais, que a fixação de datas de expiração não dá conta de resolver todos os problemas da ausência de esquecimento num mundo digitalizado, razão pela qual ela deveria ser encarada não como um substituto para as outras soluções, mas como um complemento a elas, agregando força para uma combinação mais potente de respostas. Ele explica, assim, que sua proposta "não garante perfeição e não pode aliviar a tensão entre indivíduos que querem esquecer e uma sociedade que deseja lembrar (ou vice-versa)" (MAYER-SCHÖNBERGER, 2009, p. 194, tradução nossa), e enfatiza que as datas de expiração não resolvem problemas de controle da informação que surgem em contextos relacionais envolvendo informação compartilhada entre duas ou mais pessoas - ou seja, envolvendo a privacidade informacional (e mesmo questões de confidencialidade e de propriedade intelectual). "O fim do esquecimento e as ameaças para a privacidade informacional são dois desafios complementares que requerem respostas complementares", não sendo o mecanismo de datas de expiração capaz de suplantar mecanismos voltados a garantir a privacidade informacional (MAYER-SCHÖNBERGER, 2009, p. 182, tradução nossa, grifo do original $)^{56}$.

As propostas sumarizadas por Mayer-Schönberger, incluindo a que ele mesmo apresenta, permitem inferir que a problemática é complexa e sujeita a várias abordagens. Considerando que o direito ao esquecimento parece enquadrar-se na esteira da solução

\footnotetext{
${ }^{55}$ Para maiores detalhes, inclusive com argumentos em face de outras possíveis soluções, objeções e situações, vide Mayer-Schönberger (2009, p. 189-195).

${ }^{56}$ Diante dos desafios colocados pelo fim do esquecimento, Rosen (2010) traça um panorama bem geral de algumas respostas aventadas (inclusive referindo-se à sugestão de Mayer-Schönberger). Já há, aliás, empresas oferecendo serviços para lidar com os problemas do fim do esquecimento na internet - caso da ReputationDefender (vide www.reputationdefender.com). Conforme aponta Rosen (2010), a empresa em questão monitora a reputação online de seus clientes com ações que incluem a identificação de informações ofensivas; solicitações dirigidas aos editores de sites para que as retirem o ar; e mesmo o bombardeio da internet com informações positivas ou neutras sobre seus clientes (seja mediante a criação de novas páginas ou aumentando os links que direcionam para páginas já existentes), de modo a fazer com que os resultados positivos venham a aparecer no topo das buscas feitas no Google Search, ao mesmo tempo em que os resultados negativos ficam relegados para as últimas páginas da listagem - tornando-se mais difícil encontrá-los. Trata-se de uma solução mais imediatista e evidentemente não disponível para todos.
} 
preconizada justamente pelo direito à privacidade (informacional), um resgate das transformações em torno da privacidade, à luz das modificações técnicas e sociais recentes, se impõe.

Partindo da concepção de que a privacidade é uma ideia construída no tempo na dependência de condicionantes sociais, políticos e econômicos, Doneda procura refazer, ainda que brevemente, sua trajetória histórica (DONEDA, 2006, p. 113 e ss). De acordo com ele, a atual dinâmica de juridificação da ideia de privacidade deve ser radicada no Século XIX. Isso não significa a inexistência de fenômenos anteriores ligados ao tema, nem que ele fosse inteiramente estranho a balizamentos normativos. O que não existia, contudo, era uma discussão integrada dos fenômenos sob a égide de uma ideia de privacidade. Havia, em tais épocas, instrumentos outros que, fundados em outras arquiteturas sociais e políticas, poderiam fazer as vezes do que hoje se chamaria de privacidade.

Modificações nas disposições arquitetônicas das casas e das cidades (as quais facilitaram a separação e categorização das pessoas e grupos), a penetração da ideia de individualismo no tecido social, bem como de uma concepção de que os entes públicos não mais poderiam ter ingerência sobre uma esfera privada livre, apresentam-se, segundo Doneda, como condições histórico-sociais de destaque na ascensão de uma ideia de privacidade inicialmente vinculada diretamente à noção de propriedade e caracterizada como prerrogativa de uma classe burguesa emergente. "[O] direito de propriedade era a condição inafastável para se chegar à privacidade", sendo certo que "[a]s condições de vida em que se desenvolve a revolução industrial excluem toda uma classe operária e adjacentes da privacidade que seus patrões poderiam usufruir" (DONEDA, p. 130-131). Posteriormente, contudo, sobretudo no Século XX, tal realidade veio a mudar.

Ao individualismo somam-se, portanto, os meios materiais que, em um primeiro momento, estavam à disposição da burguesia e que foram posteriormente massificados; meios estes que providenciavam de várias formas a delimitação de espaços entre os ocupantes de uma mesma casa. Estes eram de regra fornecidos pela tecnologia, como a construção de habitações coletivas, a difusão da eletrificação e de toda a infraestrutura doméstica (hidráulica, aquecimento etc.), acompanhados da diminuição do número de membros para uma família média - o que implica diretamente que menos pessoas tivessem necessidade de dividir seu quarto com outras. 
Tal fato, somado ao surgimento dos meios de comunicação de massa, modificou tanto a expectativa de privacidade quanto os mecanismos sociais que eventualmente neutralizavam ou diminuíam o impacto causado pela intrusão na vida privada de um cidadão (DONEDA, 2006, p. 133-134).

Doneda (2006, p. 34 e ss) identifica na Revolução Industrial um marco geral a partir do qual a tecnologia passou a ter um maior destaque na dinâmica da sociedade - algo que, segundo ele, veio a ganhar contornos ainda mais incrementados com o desenvolvimento tecnológico em outras áreas, como a eletrônica e as telecomunicações. Tendo adquirido relevância destacada na sociedade, o desenvolvimento e os impactos da tecnologia passaram a ser objeto de atenção e estudo em diversas áreas das ciências sociais, incluindo o direito.

O início dos debates doutrinários sobre o direito à privacidade ocorreu, não por
coincidência, como consequência direta da utilização de novas técnicas e
instrumentos que inauguraram uma época na qual a privacidade começava a [ser]
posta em xeque justamente por estas (DONEDA, 2006, p. 35-36).

A esse respeito, Doneda (2006, p. 35-36, nota de rodapé $\left.n^{\circ} 60\right)$ menciona, aliás, a preocupação de Rudolf von Ihering, apresentada no final do Século XIX, acerca da relação envolvendo um fotógrafo que desejava expor uma fotografia em vitrine e a respectiva pessoa fotografada. O destaque, contudo, fica com o pioneiro artigo intitulado "The right to privacy", de Samuel Warren e Louis Brandeis, datado de 1890.

Contextualizando o teor de sua comunicação, Warren e Brandeis (1890) chamam a atenção para a necessidade de se proteger a pessoa e de se assegurar aos indivíduos o direito de ser deixado só (right to be let alone), em face dos métodos de negócios e das invenções, então recentes, que envolveriam empreitadas jornalísticas, fotografias instantâneas e numerosos dispositivos mecânicos ameaçadores e invasores da vida privada/doméstica e ensejadores de dor mental e aflição. Um contexto em que a imprensa estaria transgredindo em todas as direções os limites de decência admissíveis e em que a fofoca teria virado um negócio perseguido descaradamente ${ }^{57}$.

Embora o assunto já se fizesse de certa forma presente em discussões anteriores, costuma-se identificar na publicação do artigo de Warren e Brandeis o marco inicial da

\footnotetext{
57 "Historicamente, a liberdade de imprensa (...) excedeu com frequência os limites naturais do respeito pelos direitos da personalidade afetando, por outro lado, bens cuja defesa interessava à própria conservação da sociedade política" (DOTTI, 1980, p. 127).
} 
discussão moderna sobre a privacidade. A observação que eles fazem encara a privacidade como um direito a ser protegido não em decorrência ou segundo a estrutura do direito de propriedade, mas como um novel direito de índole pessoal, ancorado num princípio de proteção da inviolabilidade da personalidade. Trata-se de um modo de observar a questão da privacidade que refletiu uma época própria, mas que - retrospectivamente falando - teve um alcance muito além dela. Uma comunicação que partiu de "um novo fato social, que eram as mudanças trazidas para a sociedade pelas tecnologias de informação (jornais, fotografias) e a comunicação de massa, fenômeno que se renova e continua moldando a sociedade futura" (DONEDA, 2006, p. 139) $)^{58}$.

Com as facilidades propiciadas pela evolução tecnológica (incremento na capacidade de armazenamento, facilidade de recuperação, aumento do fluxo e circulação de informações etc.), cresceu não só a variedade de possibilidades de organização e apropriação das informações, como o valor da informação em si. Apta a vários usos, "mais ela se torna elemento fundamental para um crescente número de relações", aumentando igualmente "suas possibilidades de influir em nosso cotidiano" (DONEDA, 2006, p. 153). As mudanças propiciadas pela informática, ou seja, pelo processamento automatizado da informação por computadores, contribuiu para uma alteração quantitativa e qualitativa do tratamento da informação. Por um lado, maior quantidade de informação passou a ser processada em menos tempo. Por outro, técnicas sofisticadas, que envolvem algoritmos e novos métodos, passaram a ser utilizadas, propiciando a obtenção de resultados mais valiosos, segundo diversos objetivos e utilidades (DONEDA, 2006, p. 171-173).

\footnotetext{
Esta dinâmica apresenta claras implicações no que interessa às informações pessoais. Aumenta a quantidade de informação disponível sobre uma pessoa, informações que podem influenciar a sua vida futura - uma simples busca na Internet pelo nosso nome ou pelo de pessoas conhecidas pode, em vários casos, elucidar o significado prático do registro aleatório de informações a nosso respeito. Ganha peso a imagem do computador como o cão de guarda da sociedade da informação, que não esquece jamais (DONEDA, 2006, p. 177-178).
}

\footnotetext{
${ }^{58}$ Em 1980, Dotti escrevia: "Parece que a grande meta assinalada para o jurista ao final deste século, consiste em acompanhar todo um processo de evolução material que se instalou e se movimenta à sua circunstância e, para além das antinomias que a crise revela, meditar sobre as possibilidades de formular um sistema normativo que possa compatibilizar os avanços da tecnologia com a necessidade de salvaguardar os direitos fundamentais do Homem" (DOTTI, 1980, p. 54).
} 
A respeito da pessoalidade do dado ou da informação ${ }^{59}$, Doneda $(2006$, p. 156 e ss) esclarece que uma informação pessoal caracteriza-se por ter como objeto um indivíduo identificado ou identificável ${ }^{60}$. Ou seja, ela encontra-se vinculada a uma pessoa e, portanto, revela algum aspecto objetivo dela, algo que se refere a características ou ações suas, atribuídas por força legal (como o nome ou o domicílio) ou por serem provenientes de variados atos. Não se inclui como informação pessoal, contudo, produções intelectuais e opiniões alheias sobre a pessoa.

Todas essas inovações tecnológicas, passíveis de utilização no processamento de dados pessoais, encontram-se no pano de fundo que compõe uma nova compreensão da privacidade e de proteção de dados pessoais que vem a surgir. Procurando expor como a sociedade e o direito vieram a compreender os impactos de tais mudanças tecnológicas, Doneda (2006, p. 183-201) resgata três casos que entende paradigmáticos.

Na primeira situação, ocorrida nos Estados Unidos, por volta de 1965, tem-se que o Bureau of Budget, órgão do governo norte-americano então responsável pelo orçamento, intentou criar um banco central de dados (National Data Center) voltado à unificação das diversas bases de dados pessoais de cidadãos americanos existentes nos vários órgãos administrativos federais. Unificar tais registros (cadastros de censo, trabalhistas, fiscais,

\footnotetext{
${ }^{59}$ Sobre a compreensão dos termos "dado" e "informação", importante transcrever a seguinte observação de Doneda: "Em relação à utilização dos termos "informação" e "dado", é necessário notar preliminarmente que o conteúdo de ambos os vocábulos se sobrepõe em várias circunstâncias, o que justifica uma certa promiscuidade na sua utilização. Ambos os termos servem a representar um fato, um determinado aspecto de uma realidade. Não obstante, cada um carrega um peso particular a ser levado em conta. Assim, o "dado" apresenta conotação um pouco mais primitiva e fragmentada, como observamos por exemplo em um autor que o entende como uma informação em estado potencial, antes de ser transmitida; o dado estaria associado a uma espécie de "préinformação", anterior à interpretação e ao processo de elaboração. A informação, por sua vez, alude a algo além da representação contida no dado, chegando ao limiar da cognição, e mesmo nos efeitos que esta pode apresentar para o seu receptor. Sem aludir ao significado ou conteúdo em si, na informação já se pressupõe uma fase inicial de depuração de seu conteúdo - daí que a informação carrega em si também um sentido instrumental, no sentido de uma redução de um estado de incerteza. A doutrina não raro trata estes dois termos indistintamente" (DONEDA, 2006, p. 152).

${ }^{60}$ Trata-se de uma definição semelhante àquela mobilizada pelo Tribunal de Justiça da União Europeia no caso Google vs. Mario Costeja González, a partir da Diretiva no 46/1995/CE. Afigura-se oportuna, aqui, a lembrança de algumas definições trazidas pela Lei $\mathrm{n}^{\circ}$ 12.527, de 18 de novembro de 2011 (BRASIL, 2011), conhecida como Lei de Acesso à Informação - LAI. Ela define informação como "dados, processados ou não, que podem ser utilizados para produção e transmissão de conhecimento, contidos em qualquer meio, suporte ou formato" (art. $4^{\circ}$, inciso I), e informação pessoal como sendo "aquela relacionada à pessoa natural identificada ou identificável" (art. $4^{\circ}$, inciso IV). Já por tratamento da informação deve-se entender "o conjunto de ações referentes à produção, recepção, classificação, utilização, acesso, reprodução, transporte, transmissão, distribuição, arquivamento, armazenamento, eliminação, avaliação, destinação ou controle da informação" (art. $4^{\circ}$, inciso V).
} 
previdenciários etc.) seria algo tido por natural em termos de eficiência no planejamento administrativo e à luz da lógica tecnocrática e das tecnologias existentes. Seria mais fácil, menos custoso e mais rápido, afinal, localizar informações de forma unificada do que de forma dispersa; a duplicação de informações seria evitada; haveria maior racionalização das ações de governo etc. A medida, contudo, gerou reações em vários setores da sociedade norte-americana, que identificaram problemas na concentração substancial de dados pessoais, como o próprio aumento do poder governamental. Após ouvir a sociedade numa série de audiências públicas, o Congresso norte-americano concluiu por não endossar a proposta tal como formulada pelo Bureau of Budget, eis que a privacidade dos cidadãos deveria ser protegida e respeitada. O projeto terminou, enfim, sendo descartado.

Segundo Doneda (2006, p. 188-189), o debate teria jogado luzes, porém, sobre pontos até então naturalizados. A dispersão de dados pessoais em várias fontes, se antes era a única solução possível em virtude da técnica existente, passou a ser encarada como uma opção a ser considerada segundo prós e contras. Da mesma forma ocorreu com a centralização das informações: de consequência natural e inexorável da eficiência, passou a ser encarada como mais uma opção dentre outras. Posta a situação em termos de escolha e não de necessidade, pareceu que a distribuição de dados pessoais (e não sua centralização) serviria melhor contra o uso indiscriminado dos dados dos cidadãos. De outro lado, o debate propiciou a invocação, ainda que difusa, de argumentos contrários ao projeto calcados na dignidade e na proteção da personalidade. Houve ainda menção à diferença de importância entre os diversos dados pessoais, a ensejar proteção diferenciada e não de uma mesma forma.

Com idêntica motivação de eficiência, outro caso teve desenrolar, desta feita na França, no início da década de 1970. Um órgão técnico francês procurou colocar em prática um projeto (SAFARI) que tinha como objetivo facilitar o armazenamento e a comunicação de dados pessoais de cidadãos franceses entre os órgãos da administração pública, mediante sistemas informatizados. O projeto culminaria mesmo na atribuição de um número invariável a cada pessoa no momento do nascimento - e que a identificaria por toda a vida. Não tendo sido bem recebido, e diante da comoção causada, o primeiro-ministro francês baixou ordem impedindo qualquer interconexão de dados entre ministérios - medida que terminou por interromper e encerrar o projeto em questão. Discussões posteriores na França conduziram à elaboração de uma influente lei de proteção de dados em 1978 (DONEDA, 2006, p. 190-191). 
O último caso relatado por Doneda (2006, p. 192 e ss) teve curso na Alemanha. A então República Federal da Alemanha aprovou em 1982 uma lei regulamentando o censo que deveria ser realizado. Tal diploma normativo, contudo, continha vários dispositivos que geraram desconfiança por parte da população quanto à metodologia de coleta e o destino das informações. Em princípio, os dados voltar-se-iam para finalidades estatísticas, mas havia insegurança quanto à possibilidade de o governo passar a controlar as atividades e a condição pessoal dos alemães. Tendo a sociedade chamado a atenção para os problemas, desencadeouse um processo que culminou com pronunciamento da corte constitucional alemã suspendendo o referido censo e declarando inconstitucional a sua lei em face dos dispositivos constitucionais que protegiam o direito geral de personalidade.

Em sua decisão, a corte constitucional alemã trouxe à luz várias ideias que até hoje são, de acordo com Doneda, referência na questão da proteção de dados pessoais. Dentre elas, pode-se destacar a necessidade de respeito à finalidade na coleta de dados pessoais; a ideia de que não se poderia tomar em consideração apenas a natureza das informações, sendo determinante observar a sua necessidade e utilização, eis que, dadas as condições automáticas de processamento de dados, sempre pode surgir um novo valor para uma determinada informação, não havendo mais dados sem importância; o direito dos indivíduos de controlar suas informações, decidindo quando e sob quais limites seus respectivos dados pessoais poderiam ser utilizados (autodeterminação informativa); e a ideia de que a proteção de dados pessoais seria um direito fundamental que protege a personalidade.

A sentença reconhece também que o estágio de desenvolvimento da tecnologia informática utilizada no processamento das informações recolhidas com o censo era um fator determinante a ser levado em conta. Somente com a informática tornava-se plausível o dano à personalidade causado pela elaboração de perfis formados pelos dados sobre indivíduos: "a capacidade tecnológica de memorizar informações pessoais concernentes às pessoas é praticamente ilimitada (...). Estas informações, se cruzadas com outras fontes de dados, podem determinar um perfil da pessoa, completo ou parcial, sobre o qual os indivíduos em questão não têm controle, e a verdade não pode ser confirmada. (...) A possibilidade de adquirir informações e de exercitar influência foi incrementada até graus jamais conhecidos" (DONEDA, 2006, p. 195-196, com citação de Mario Panebianco). 
Toda essa evolução social, que conta com o consórcio de várias "causas" (e enseja várias consequências) terminou por ressignificar a temática da privacidade, agregando-lhe novos elementos e reordenando sua concepção em torno (da proteção) dos dados pessoais ${ }^{61}$. "A trajetória percorrida pelo direito à privacidade reflete tanto uma mudança de perspectiva para a tutela da pessoa quanto sua adequação às novas tecnologias de informação" (DONEDA, 2006, p. 141). Assim, se em sua concepção inicial, o direito à privacidade possuía uma conotação essencialmente negativa, no sentido de proteger a intimidade, a vida íntima, pessoal e doméstica de cada ser humano, impondo aos outros um dever geral de abstenção ou não-fazer (deixando os demais em paz), na sua atual caracterização ele se propõe a ir além, abarcando o direito da pessoa humana de ter seus dados pessoais protegidos, mediante controle de sua coleta e utilização (SCHREIBER, 2014, p. 136 e ss) ${ }^{62}$.

Não se trata de admitir uma ruptura e abandonar concepções pretéritas, mas da necessidade de tomá-las em consideração de forma integrada à nova realidade social e a uma série de interesses que perfazem o pano de fundo da privacidade e que a rodeiam a ponto de alterar seu eixo gravitacional. Resgatando lição de Stefano Rodotá, Doneda (2006, p. 23) aponta que o direito à privacidade deslocou-se do eixo "pessoa-informação-segredo" para o eixo "pessoa-informação-circulação-controle". Nesse sentido, a privacidade deixa de ser um direito egoístico ao isolamento e à tranquilidade, performador de um espaço reservado à nãointromissão definido segundo parâmetros substanciais, para assumir um caráter formal, uma forma, que possibilita a construção de uma esfera privada própria, dotada de liberdade de escolhas e de administração dessas escolhas e mediante a qual afigura-se possível "a construção da individualidade e o livre desenvolvimento da personalidade sem a pressão indevida de mecanismos de controle social". O caráter relacional assumido pela privacidade abre espaço para a determinação, assim, do "nível de relação da própria personalidade com as outras pessoas e com o mundo exterior" (DONEDA, 2006, p. 146).

\footnotetext{
${ }^{61}$ Deve-se atentar, aqui, para o fato de que a privacidade é uma ideia que se presta a muitos usos e concepções, ensejando tanto visões reducionistas quanto holísticas na sua caracterização. Segundo Doneda (2006, p. 105106), mesmo o marco comum de Warren e Brandeis não é preciso: eles não afirmam cabalmente que o direito a ser deixado só (right to be let alone) "traduziria propriamente o conteúdo do direito à privacidade". Tal situação, contudo, deveria ser vista menos como um defeito e mais como uma realidade com a qual se deve lidar, na busca pela compreensão da temática à altura de sua complexidade e das mudanças sociais.

${ }^{62}$ Nas palavras de Bucar (2013, p. 16): “[A]ltera-se a acepção clássica do direito a ser deixado só para entender a privacidade como o direito ao controle espacial, contextual e temporal dos dados pessoais, de modo que se permita ao interessado ter ciência e manifestar seu consentimento (quando necessário) quanto ao exato ambiente, contexto e tempo em que suas informações serão projetadas, de modo a proteger a sua vida privada (sobretudo seu perfil existencial) da violação ocasionada pela estigmatização ou pela discriminação social".
} 
A privacidade assume, portanto, posição de destaque na proteção da pessoa humana, não somente tomada como escudo contra o exterior - na lógica da exclusão - mas como elemento positivo, indutor da cidadania, da própria atividade política em sentido amplo e dos direitos de liberdade de uma forma geral (DONEDA, 2006, p. 142).

A evolução da ideia de privacidade parece inscrever-se, portanto, numa trajetória de reação ou de "legítima defesa" a práticas tecnocráticas escravizadoras da liberdade das pessoas (DOTTI, 1980, p. 54). Práticas e técnicas estas que, numa constante evolução e aproveitadas pelos meios de comunicação de massa, estão a suscitar novas diferenciações no discurso da privacidade, a ponto de ensejar a densificação de um específico direito ao esquecimento $^{63}$.

\subsection{O que esquece o direito ao esquecimento?}

A memória e o esquecimento são dois lados da mesma moeda. Não sendo um regresso ao passado, nem mero armazém de dados resgatáveis sob demanda, a memória caracteriza-se por ser uma função de uso permanente (mas sempre no presente), que atua justamente esquecendo. Por outras palavras, ao esquecer a memória "evita que o sistema bloqueie a si próprio em razão de uma coagulação dos resultados de observações anteriores" e, assim, libera-o em termos de capacidade para processar informações (LUHMANN, 2007, p. 457, tradução nossa). Aquilo que não é esquecido, portanto, configura uma realidade construída dentro do sistema a partir de provas de consistência de operações do sistema contra operações do sistema (LUHMANN, 2007, p. 459).

\footnotetext{
${ }^{63}$ Schreiber (2014, p. 172) começa sua observação acerca do direito ao esquecimento falando justamente da internet - ambiente que nada esquece: "[a] internet não esquece. Ao contrário dos jornais e revistas de outrora, cujas edições se perdiam no tempo, sujeitas ao desgaste do seu suporte físico, as informações que circulam na rede ali permanecem indefinidamente. Pior: dados pretéritos vêm à tona com a mesma clareza dos dados mais recentes, criando um delicado conflito no campo do direito. De um lado, é certo que o público tem direito a relembrar fatos antigos. De outro, embora ninguém tenha direito de apagar os fatos, deve-se evitar que uma pessoa seja perseguida, ao longo de toda a vida, por um acontecimento pretérito".
} 
Tais considerações, tomadas em conjunto com as agruras vividas pelas pessoas referidas nos casos elencados no capítulo 1, e com os efeitos negativos em termos de poder e tempo sumarizados a partir de Mayer-Schönberger ${ }^{64}$, permitem afirmar, com Ost (2001, p. 171), que o esquecimento é tanto necessário, quanto perigoso. E “[s]e o esquecimento, reverso da memória, apresenta essa natureza ambígua, é porque também a memória é necessária (dissemos a que ponto ela era constitutiva do social) e perigosa" (OST, 2001, 162).

Apresentando-se, assim, de forma constitutiva não só para sistemas psíquicos, mas também para sistemas sociais, o esquecimento (ou a memória) não configura algo novo para o direito. Consoante anota Ost (2001, p. 163), “[p]resente no próprio fundamento do direito, o esquecimento acompanha-o também na sua vida quotidiana, ritmando os seus desenvolvimentos, escandindo as suas idas e vindas”. O esquecimento está presente, assim, em várias manifestações jurídicas.

A prescrição, instituto tão conhecido dos operadores do direito, apresenta-se como um exemplo bem claro de um esquecimento juridicamente programado. Por meio dela, na impossibilidade de se realizar tal como inicialmente prescrito, o direito adapta-se aos fatos ou à realidade que contrariamente se consolida e passa, assim, a consagrar uma outra visão de justiça, qual seja, aquela "que quer que esqueçamos aquilo que durou demasiado sem conseguir realizar-se" (OST, 2001, p. 167).

Para além do instituto da prescrição e de formulações específicas em torno do esquecimento na legislação ${ }^{65}$, Ost destaca o direito ao esquecimento como uma das facetas do respeito à vida privada:

\footnotetext{
${ }^{64}$ Vide tópico anterior.

${ }^{65}$ Se, no campo cível, a prescrição permite a libertação do devedor de obrigações pessoais, em função do credor não ter exercido tempestivamente o seu direito (OST, 2001, p. 167), na seara penal a questão do esquecimento mistura-se com a ideia de perdão e pode adquirir contornos extremos: do reconhecimento de imprescritibilidades que nada esquecem a anistias que tudo esquecem (OST, 2001, p. 178). De ordinário, contudo, tem-se o estabelecimento de leis que fixam antecipadamente, de uma forma geral e abstrata, válida para qualquer pessoa e qualquer infração, os prazos prescricionais após os quais a pessoa pode reivindicar o direito de ser esquecida juridicamente por determinadas ocorrências. Embora não se imponha um silêncio sobre os fatos ocorridos, entende-se que, após o transcurso de um determinado lapso temporal, o interesse na persecução criminal ou judicial termina por se desfazer - afinal, o fluir do tempo conduz à provável extinção do escândalo social causado pelos fatos, ao desaparecimento de provas, ao desgaste da memória das testemunhas e da indignação pública etc. Trata-se de uma situação que não gera tanta controvérsia, justamente em virtude de sua previsão antecipada, geral e abstrata (OST, 2001, p. 178-182). As anistias, contudo, já suscitam maiores controvérsias, pois são concedidas circunstancialmente e após a ocorrência da infração. Por serem reconhecidas posteriormente, associam-se fortemente à ideia de perdão. Podem ser periódicas e decorrentes de decisões envolvendo política penitenciária ou podem adquirir feição pontual e política. Sendo pontuais e políticas, voltam-se ou às penas
} 
Quando, personagem pública ou não, fomos empurrados para a boca de cena e colocados sob os projectores da actualidade - muitas vezes, é preciso dizê-lo, uma actualidade penal -, temos o direito, depois de um certo tempo, de sermos deixados em paz e cair no esquecimento e anonimato de onde nunca gostaríamos de ter saído. Numa decisão de 20 de abril de 1983, Mme. M. c. Filipachi et Cogedipresse, o Tribunal de Grande Instância de Paris consagrou esse direito em termos muito claros: "Tendo em conta que qualquer pessoa que se viu envolvida em acontecimentos públicos pode, com o tempo, reivindicar o direito ao esquecimento; que a recordação desses acontecimentos e do papel que ela desempenhou nisso é ilegítima se não se fundar nas necessidades da história ou se puder ser de natureza a ferir a sua sensibilidade; tendo em conta que o direito ao esquecimento que se impõe a todos, incluindo aos jornalistas, deve igualmente beneficiar todos, incluindo os condenados que pagaram a sua dívida à sociedade e nela tentam reinserir-se" (OST, 2001, p. 170-171).

É de se perceber que a concepção trazida por Ost, plasmada numa semântica de privacidade enquanto direito de ser deixado em paz (válida ainda na atualidade, mas não por si só, conforme exposto no tópico anterior), menciona uma decisão de 1983 que já se utiliza do léxico de um direito ao esquecimento, invocável por todos (inclusive criminosos que já cumpriram suas penas) e oponível também contra todos - com destaque aos jornalistas.

René Ariel Dotti, em trabalho de 1980, também já mencionava um direito ao esquecimento, que evoluía "à medida em que a jurisprudência ia aclarando as silhuetas e o conteúdo do direito à privacidade" (DOTTI, 1980, p. 90). Compõem essa evolução, segundo ele, casos como o Melvin vs. Reid e o Marlene Dietrich ${ }^{66}$. No primeiro, julgado pelo Tribunal de Apelação da Califórnia em 1931, tem-se que o produtor de cinema Reid fez um filme, em 1925, baseado na vida passada de Gabrielle Darley - pessoa que havia tido uma vida agitada (inclusive com prostituição e acusação de assassinato (com posterior absolvição em 1918)) -, mas que veio a casar (com Bernard Melvin) e a levar uma vida "digna e honrada, exemplar em todos os sentidos, merecendo o bom conceito dos amigos do casal" (DOTTI, 1980, p. 9091). A utilização, contudo, do nome real de Gabrielle Darley no enredo e nos anúncios do filme abalaram-na com uma dor moral que chegou a repercutir em sua saúde e deu ensejo à

(anistia menor) ou aos fatos (anistia maior). Na anistia menor, as condenações são apagadas e as execuções das penas interrompidas. $\mathrm{Na}$ anistia maior, extingue-se a ação pública, uma vez que os fatos "são reputados como não tendo sido delituosos" - o que abre toda a problemática envolvendo um esquecimento forçado, uma amnésia institucional, uma ofensa à verdade histórica e ao direito à memória (OST, 2011, p. 182-187).

${ }^{66}$ Destacados, aliás, expressamente nos votos condutores dos Recursos Especiais no 1334097 e $n^{\circ} 1335153$. 
postulação judicial por reparação. Ao apreciar o caso, o tribunal terminou por reconhecer um direito ao esquecimento, ainda que não o tenha mencionado especificamente (DOTTI, 1980, p. 91) ${ }^{67}$. Quanto ao caso Marlene Dietrich (de 1955), Dotti (1980, p. 92) destaca que o Tribunal de Paris deixou asseverado expressamente que as recordações da vida privada pertenceriam ao patrimônio moral de cada indivíduo, não sendo permitido a ninguém publicálas (ainda que sem má intenções) sem a autorização inequívoca daquele cuja vida se pretende narrar.

Rodrigues Junior (2013a) reconhece que, no Brasil, o interesse doutrinário pelo direito ao esquecimento não é novo, afigurando-se o início da década de 1990 como o marco a partir do qual essas discussões teriam ganhado corpo. De toda forma, a discussão, segundo ele, "transitava entre o Direito do Consumidor e o Direito Penal, com fortes conexões com o prazo de armazenamento de dados individuais" (RODRIGUES JUNIOR, 2013a). Os focos de então eram, assim, os registros criminais e de inadimplência, bem como a natureza e a possibilidade de se assegurar um direito ao esquecimento correlato. Os debates teriam chegado, de uma forma geral, ao reconhecimento do direito ao esquecimento como integrante do rol dos direitos de personalidade - sem, contudo, ter havido consenso quanto ao seu âmbito de proteção e os limites de seu exercício (RODRIGUES JUNIOR, 2013b). Os estudos mais recentes, contudo, já teriam agregado novos sentidos ou focos diferentes dos inicialmente abordados, em virtude, sobretudo, dos contínuos desenvolvimentos tecnológicos que ameaçam ou impedem o esquecimento.

Embora "limitados" ao ambiente televisivo, os precedentes do STJ (Recursos Especiais $n^{\circ} 1334097$ e $\left.n^{\circ} 1335153\right)$ terminaram por catalisar, no Brasil, a ampliação da discussão dos meios jurídicos para a sociedade de uma maneira geral, gerando comunicações as mais variadas - inclusive dos meios de comunicação de massa, dado seu interesse direto no assunto (de regra, contrário ao direito ao esquecimento). De sua sorte, a decisão do Tribunal de Justiça Europeu no caso Google vs. Mario Costeja González teve efeitos semelhantes não

\footnotetext{
${ }^{67}$ Sobre o caso, Wright (2015) aponta que a corte foi excepcionalmente moralista na sua linguagem, na sua tônica e na sua razão fundamental. Dentre os trechos da decisão por ele transcritos, destaca-se o seguinte: "a publicação...de incidentes desagradáveis da vida passada da apelante depois de sua reforma, juntamente com seu verdadeiro nome, não se justificou por qualquer padrão de moral ou ética conhecido por nós e foi uma invasão direta ao seu inalienável direito de procurar e obter felicidade, garantido por nossa constituição. Quer nós chamemos isto de um direito à privacidade ou de outro nome não é essencial" (In WRIGHT, 2015, p. 407, tradução nossa).
} 
só na União Europeia ${ }^{68}$, mas amplamente no mundo, incluindo o Brasil. O foco, agora, passou a ser a discussão de um direito ao esquecimento no âmbito da internet, com destaque para a viabilidade de sua implementação no mundo digital e para os riscos que ele carrega.

No tocante aos riscos, a lembrança de Ost ecoa: se o esquecimento é necessário, ele também se apresenta perigoso. Contra um discurso do direito ao esquecimento, vozes se levantam preocupadas com a possibilidade de censura, de ofensa à liberdade de imprensa e de informação e de ofensa à memória e à história ${ }^{69}$.

Ao se deparar com informações de que a Comissão Europeia estaria trabalhando numa revisão do quadro normativo de proteção de dados pessoais ${ }^{70}$, que viria a incluir a previsão expressa de um direito ao esquecimento, Peter Fleischer, executivo do Conselho de Privacidade Global do Google, apresentou uma comunicação (FLEISCHER, 2011) destacando, de saída, que a privacidade estaria sendo usada cada vez mais para justificar a censura: uma espécie de novo "pretinho básico da moda censuradora". Ideias pugnando o direito de ser esquecido, a expiração de conteúdos, a limitação temporal da coleta de dados pelas companhias (por prazo não superior ao necessário), a programação de computadores para "esquecer" à semelhança do cérebro humano etc. fariam parte, segundo ele, de debates relacionados, todos, com a justificação da censura. Tratar-se-ia de um contramovimento da privacidade que estaria ganhando força em face de um mundo onde há cada vez mais conteúdo online, encontrável e compartilhável, e cujo desfecho ainda dependeria de desafios e contradesafios. De toda forma, ele reconhece a existência de sérias questões em ambos os lados da contenda.

\footnotetext{
${ }^{68}$ A discussão acerca do direito ao esquecimento no ambiente digital (internet) na União Europeia não era nova, porém estava ainda no âmbito de propostas (legislativas) de revisão do marco normativo e de discussões (na sociedade) a seu respeito. A decisão do Tribunal de Justiça Europeu no caso Google vs. Mario Costeja González terminou, porém, por atualizar o sentido interpretativo do marco normativo já existente (mormente a Diretiva ${ }^{\circ}$ 46/1995/CE) à luz dos novos desafios propostos pelo ambiente digital, reconhecendo um direito ao esquecimento e colocando-o em execução. Isso terminou por incitar ainda mais a discussão sobre o assunto - não mais somente pelos problemas teóricos que suscita, mas pelo viés prático que a implementação da decisão demanda.

69 "É real a possibilidade de se confundir a retirada de dados da rede a um ocultamento da realidade. Entretanto, os contornos do referido direito [ao esquecimento] evidenciam que não será absoluto. Seus limites serão impostos por outros direitos caros à sociedade, como direito à informação e à liberdade de expressão, em uma espécie de ponderação sobre o interesse em jogo" (LIMA, 2013).

${ }^{70}$ Para maiores detalhamentos, conferir Rosen (2012) e Lima (2013).
} 
Reagindo a tal cenário, Fleischer (2011) aponta que o debate em torno de um direito ao esquecimento ou direito ao olvido deveria ter em mente três diferenças em termos de produção/circulação dos dados ou das informações ${ }^{71}$.

A primeira diz respeito a conteúdos postados pela própria pessoa, que posteriormente pretende retirá-los ou deletá-los. Tratar-se-ia de uma situação, em princípio, segundo ele, mais fácil e menos controversa, a indicar não haver maiores problemas no reconhecimento de sua admissão ou possibilidade. Apagar uma determinada foto, postagem ou comunicação de uma página da internet ou perfil próprios não significa que ela, contudo, deixará de figurar na internet. Pode não ser mais mostrada para o público, mas não há garantias de que ela tenha sido efetivamente excluída da internet - seja porque ainda pode figurar em arquivos ou bancos de dados de provedores, seja porque ela pode ter sido copiada, reproduzida, arquivada ou compartilhada por alguém. Na esteira do que aponta Rosen (2012), admitir o direito ao esquecimento aqui, nos moldes europeus, serviria para os usuários colocarem pressão sobre provedores, de forma a confirmar a exclusão efetiva dos dados dos arquivos e o cumprimento mesmo de alegadas e declaradas políticas de privacidade.

A segunda categoria já se afigura mais controversa. Trata-se justamente da situação em que, apesar de alguém já ter deletado sua própria postagem (figura, foto, texto etc.), seja por qual motivo for, identifica que um terceiro ou terceiros já a tinham copiado e reproduzido ou repostado em outra página ou site. Há a possibilidade clara de o interessado buscar o contato direto com a pessoa ou as pessoas que reproduziram o conteúdo, na busca pela sua retirada. Mas, indaga Fleischer, e se tais pessoas não forem encontradas? Ou se não responderem ou, pelo contrário, responderem se negando a retirar as reproduções? Ações judiciais podem ser intentadas, certamente, mas deve-se ter em mente os custos e o tempo despendidos em tal empreitada. A própria plataforma provedora (Facebook, por exemplo) poderia ser demandada diretamente para deletar o conteúdo, mas isso a colocaria na posição delicada de ter de apagar conteúdo da página ou site sem prévia anuência do dono e de ter de

\footnotetext{
71 A “classificação" feita por Fleischer é comumente referida nos estudos acerca do direito ao esquecimento. Contudo, embora trabalhe no Google, Fleischer não apresenta tal comunicação como um pronunciamento oficial da empresa, mas como uma postagem num blog pessoal. Assim, não se pode dizer, a partir dela, que o Google, ao colocar em prática a decisão do Tribunal de Justiça Europeu, tenha acatado tal classificação, nem que a valore tal como Fleischer o faz. A partir de Toobin (2014), pode-se dizer que o Google toma em consideração, pelo menos em parte, algumas das questões levantadas por Fleischer, mas não se pode concluir com exatidão a extensão disso, nem o seu sentido. A respeito, um estudo empírico das decisões do Google far-se-ia necessário.
} 
arbitrar entre a privacidade de alguém e a liberdade de expressão de outrem (FLEISCHER, 2011).

Pode-se acrescentar que a situação ganha contornos dramáticos se se considerar que as ferramentas comunicacionais à disposição na internet permitem os mais variados e criativos usos, a partir da mistura, remodelagem e recontextualização de informações digitais de variadas fontes ${ }^{72}$. Para além do "mero" compartilhamento descontextualizado da informação original, há a possibilidade da criação de memes que recontextualizam os dados e podem "viralizar" na internet, configurando uma situação que excede em muito a capacidade de controle do criador/detentor original da informação. Dadas as nítidas insuficiências de uma ação pulverizada ou "no varejo", a consciência de tal contexto parece reforçar a busca por soluções "no atacado", dirigidas aos provedores ou às plataformas diretamente - o que conduz a discussão para a seara das responsabilidades dos provedores e das soluções permitidas pelo estado da técnica atual.

A terceira diferença levantada por Fleischer (2011) diz respeito à informação postada ou produzida por um terceiro sobre alguém. A pessoa a quem a comunicação se refere pode pretender deletá-la? Conforme anota Rosen (2012), aqui parecem radicar as questões mais sérias envolvendo a liberdade de expressão e a privacidade. É certo, prossegue Fleischer (2011), que há mecanismos no direito que, embora custosos e demorados, encontram-se claramente solidificados para permitir o combate e a indenização em face da disseminação de informações falsas, não-verdadeiras ou difamatórias. Mas como o caso em questão radica na demanda por privacidade e como ela, de sua sorte, não se baseia em mentiras, mas em fatos ou informações verdadeiras, não haveria como não reconhecer no discurso da privacidade uma ofensa à liberdade de expressão e, portanto, uma censura. A alegação de ofensa à privacidade colocaria em terceiros o ônus de provar que sua publicação ou comunicação estaria de alguma forma excepcionada e permitida (em função, por exemplo, de atividades jornalísticas, artísticas ou literárias). "Ao invés de uma plataforma neutra, isso poderia transformar o Google, por exemplo, num censor-chefe para a União Europeia - um papel que ele não quer desempenhar" (ROSEN, 2012, p. 92, tradução nossa) ${ }^{73}$.

\footnotetext{
${ }^{72}$ A respeito, vide Mayer-Schönberger (2009, p. 88 e ss).

${ }^{73}$ Embora seja um diploma legislativo bastante novo, pendente de regulamentação e de uma decantação (a ser verificada com o tempo e a partir dos usos que serão dados aos seus dispositivos), deve-se destacar que o Marco Civil da Internet - Lei no 12.965, de 23 de abril de 2014 (BRASIL, 2014) - dá encaminhamentos, no Brasil, para
} 
Outras comunicações há que se colocam em rota de colisão com o direito ao esquecimento. Lemos (2014) propõe esquecer o direito ao esquecimento, um fantasma cujo reconhecimento, calcado na possibilidade de remoção de informações irrelevantes, imprecisas, inadequadas ou excessivas, teria aberto uma caixa de Pandora, dada sua tamanha indeterminação. Lemos destaca que o direito ao esquecimento conflita com o direito à liberdade de expressão e que, em função disso, "as decisões sobre ele deveriam no mínimo sujeitar-se ao "devido processo legal", sendo decididas por juízes, e não por conselhos privados que adquirem poder sobre vastos volumes de informação" (LEMOS, 2014) ${ }^{74}$. Ademais, "[p]aíses que passaram por regimes militares estão justamente em busca de reconstruir passado, e não de apagá-lo" (LEMOS, 2014). Este último ponto suscita o argumento, assim, do insulto à história.

Afastando-se de uma discussão calcada numa oposição abstrata entre direitos concorrentes entre si (privacidade versus informação), Wright (2015) direciona seus argumentos não para asserções dogmáticas sobre privacidade, autonomia, interesse público ou para a construção de fórmulas, mecanismos ou testes jurídicos, mas para problemas práticos envolvendo a implementação do direito ao esquecimento - ao menos tal como ele está a se delinear em sua forma de amplo espectro reconhecida na União Europeia. Seus pontos de vista sustentam-se em evidências das ciências sociais que envolvem considerações psicológicas, limites cognitivos, incentivos e padrões de interesse de pessoas e instituições. Novamente aqui aparecem argumentos envolvendo custos.

Um primeiro ponto a destacar, segundo Wright, diz respeito à capacidade de avaliação acerca da relevância, irrelevância, atualidade ou obsolescência de uma informação ou de seu interesse ou desinteresse público. Indagar sobre a permanência da relevância de uma informação, tida por precisa, por exemplo, traz para aquele incumbido de decidir a necessidade de conhecer sobre os contextos e circunstâncias particulares capazes de justificar a busca pela respectiva informação no futuro. Tal conhecimento, contudo, nem a pessoa interessada em deletar a informação possui inteiramente, pois se trata de algo disperso no

muitos dos pontos levantados por Fleischer (o que não significa, evidentemente, ausência de problemas ou de disputas ou mesmo de usos interpretativos os mais variados). Quanto à responsabilidade por danos decorrentes de conteúdo gerado por terceiros, conferir em especial os artigos 18 a 21 da referida lei (reproduzida, na íntegra, como anexo ao presente trabalho).

${ }^{74}$ Neste ponto, e contrariamente à decisão europeia no caso Google vs. Mario Costeja González, o Marco Civil da Internet caminha no sentido apontado por Lemos. A respeito, conferir o anexo do presente trabalho. 
tempo, no espaço e entre muitas outras partes - partes essas que sequer terão notícia do pedido de remoção e ficarão sujeitas (se é que ficarão) a meios alternativos mais custosos de acesso à informação removida.

O problema mais significante é que as decisões de remoção ou desindexação que afetam aquelas circunstâncias futuras de certa forma imprevisíveis irão geralmente ser feitas a pedido de uma parte excepcionalmente interessada, cuja versão das circunstâncias relevantes irá normalmente permanecer incontestada por pessoas versadas, quando não simplesmente apresentada ex parte (WRIGHT, 2015, p. 414, tradução nossa).

As assimetrias em termos de parcialidade do pedido, baseadas em fortes interesses próprios e num acesso a informações maior por parte daquele que solicita a remoção ou a desindexação, não param por aí. Segundo Wright (2015), elas parecem se apresentar também nos incentivos financeiros que movem as partes (e não os motores de busca) a apresentar ações judiciais pleiteando indenizações materiais ou honorários advocatícios ${ }^{75}$.

$\mathrm{O}$ autor entende ainda que as pessoas incumbidas de tomar decisões sobre a privacidade não deveriam confinar-se a pensar tais questões a partir da figura mental de um requerente, enquanto pessoa que vive e respira, contra uma sociedade abstrata, antipática, sem face, sem corpo, mas sim ter em mente aquelas pessoas, atualmente anônimas, que no futuro podem ser injustamente afetadas pela indisponibilidade ou disponibilidade somente com elevados custos das informações deletadas (WRIGHT, 2015).

Quanto à parcialidade dos pedidos, e indo além mesmo da possibilidade de enganos conscientemente produzidos nas justificativas para deletar ou desindexar informações, Wright (2015) chama a atenção para as inclinações psicológicas envolvidas na questão, que levariam as pessoas interessadas a serem tendenciosas quando se trata de avaliar e julgar o próprio passado - algo que sistematicamente distorce o senso de responsabilidade sobre atos pretéritos. A ideia central, psicologicamente explicada, segundo o autor, seria de que as pessoas tendem a relacionar ou atribuir eventos positivos a si mesmas, ao mesmo tempo em que atribuem eventos negativos a outras causas - externamente determinadas. Ademais, ao mesmo tempo em que negam tendências ou inclinações em si mesmas, as pessoas são prontamente capazes de identificá-las nos outros. Isso teria reflexos diretos na

75 Tal apontamento, contudo, parece contrastar com as observações de Mayer-Schönberger (2009) e Fleischer (2011) no tocante aos custos (nem tanto incentivadores) de se embarcar em tais empreitadas judiciais. 
maneira como os indivíduos encaram e relatam seus fatos passados, fazendo com que suas visões próprias terminem por adquirir um peso maior sobre visões contrárias. É também com argumento de índole psicológica que Wright (2015) questiona, ainda, até que ponto uma pessoa pode de fato mudar amplamente sua personalidade para melhor com o avançar de sua idade.

Ele chega a questionar também se o direito ao esquecimento não seria uma forma de paternalismo que, baseando-se no medo de má-interpretação de informações verdadeiras ou de uma sobrecarregada atribuição de valor a elas, termina por afetar escolhas de relacionamento, não mediante a disponibilização de mais informações ou de explicações incontroversas a seu respeito, mas através da privação de informações ou do aumento dos custos em obtê-las (WRIGHT, 2015).

Ele prossegue ainda apresentando dúvidas quanto ao verdadeiro empoderamento dos indivíduos no controle das informações, quando se considera que o acesso a elas fica nas mãos do governo ou de cortes (que definem critérios e regras) e empresas ou entidades privadas (que devem tomar decisões, a partir das regras definidas). Enfim, e na esteira da tradição norte-americana, ele conclui pela necessidade de um "recall" num direito ao esquecimento tão amplamente formatado, de maneira a redimensioná-lo em remédios legislativos ou típicos do common law, mais específicos, particularizados, refinados e contextualizados, tendo em vista uma paridade socioeconômica e também critérios de igualdade (WRIGHT, 2015).

Traçando um panorama do direito ao esquecimento, com ênfase em casos concretos caros ao tema (como os recursos especiais do STJ e o caso Lebach, dentre outros), Rodrigues Junior (2013a, 2013b, 2013c, 2013d) aponta que a "tensão entre o erro e o direito de não o ver propagado indefinidamente no tempo está na raiz dos debates sobre o chamado "direito ao esquecimento"” (2013b). Segundo o autor, tais debates, embora importantes, ainda se afigurariam confusos na atualidade, não sendo possível a indicação, numa perspectiva comparada, de uma tendência clara acerca do direito ao esquecimento - algo decorrente em grande medida das diferenças entre realidades nacionais e entre os casos concretos em si (cujas decisões estariam fortemente atreladas aos respectivos elementos descritivos que tornam cada caso único). 
Ele chama a atenção para alguns pontos relevantes para o debate. Destaca que a imprensa possui um papel de informar e de accountability que não pode ser ignorado. De outro lado, reconhece que a internet amplificou as possibilidades de uso das liberdades comunicativas, a ponto de permitir "a prática de verdadeiras políticas de extermínio moral dos indivíduos" (RODRIGUES JUNIOR, 2013d). Ademais, dificuldades extremas apresentar-seiam na busca pela distinção entre elementos históricos e a proteção da intimidade (seja de pessoas vivas ou mortas).

\footnotetext{
Não há qualquer julgado conhecido no qual se tenha discutido a exposição de fatos sobre criminosos de guerra (de quaisquer guerras, embora os nazistas ocupem posição de preeminência nesse campo), muitos dos quais foram condenados a penas não capitais e tiveram longas existências após isso. Em relação a eles não houve preocupação com a ressocialização ou com o estigma. O caso Lebach-1 não teve idêntica dimensão de um crime de guerra, mas tratou-se de um ato criminoso que ganhou as páginas da história criminal alemã. Haveria fundamento para diferenciar seus autores e outros assassinos contemporâneos? (RODRIGUES JUNIOR, 2013d).
}

A propósito, deve-se esclarecer que a menção a um caso Lebach-1 (que foi o caso relatado neste trabalho no capítulo 1) dá-se em função da existência do caso Lebach-2, de 1999, o qual revisitou o problema do direito ao esquecimento, culminando, contudo, num julgamento distinto do primeiro. Conforme relata Rodrigues Junior (2013d), no caso Lebach2 tem-se que, em 1996, o canal de televisão SAT 1 resolveu fazer uma série sobre crimes que entraram para a história, abordando, dentre outros, justamente o crime que estava na raiz do caso Lebach-1 - desta feita, contudo, mudando nomes de pessoas envolvidas, deixando de exibir suas imagens e contextualizando a situação com comentários explicativos. Com argumentos semelhantes aos anteriormente aduzidos, os envolvidos no crime do lugarejo Lebach contestaram a liberdade comunicativa da emissora de televisão para veicular o caso. Decidindo, desta feita, em favor da emissora, o Tribunal Constitucional Federal alemão tomou em consideração que representações da pessoa, passíveis de distorcer sua imagem ou de estigmatizá-la ou de dificultar sua ressocialização, enfim, de impedir o livre desenvolvimento da personalidade, podem vir a limitar a liberdade de radiodifusão. Tal não seria o caso, todavia, na hipótese, porque, diferentemente da situação do caso Lebach-1, não teria havido sensacionalismo (com exposição de nomes e fotos), capaz de dificultar a ressocialização. Ademais, considerando-se o tempo decorrido desde o evento (o crime data de 1969), os riscos para a ressocialização teriam sido bem minorados. 
Ainda sobre o caso Lebach-2, Sarlet (2015) destaca que o Tribunal Constitucional Federal alemão teria deixado claro que nem o julgamento do caso Lebach-1 nem o direito geral de personalidade concederiam aos autores de crimes o direito subjetivo de impedir que a opinião pública possa ser novamente confrontada com os fatos.

Isso pelo fato de que, no primeiro caso, o TCF [Tribunal Constitucional Federal] apenas constatou que o direito de personalidade está protegido de uma temporalmente ilimitada atenção dos meios de comunicação com a pessoa do criminoso e sua vida privada, mas não assegura uma absoluta imunidade em relação a uma indesejada representação pública de acontecimentos relevantes para a personalidade, sendo, portanto, determinante o quanto, no caso concreto, a difusão pela mídia de informações pode afetar os direitos de personalidade (SARLET, 2015).

Os riscos em torno do direito ao esquecimento, como se percebe, são muitos. São reais as possibilidades de ele vir a ser mobilizado em situações problemáticas para a liberdade de expressão, de imprensa e de informação, para a memória e para a história. São reais também as dificuldades de sua implementação efetiva (à luz dos interesses de quem o postula) e adequada (à luz dos demais interesses em jogo). Tais constatações, porém, não devem servir como uma justificativa para se bloquear a discussão aprioristicamente, evitando seu desenvolvimento - até porque, ainda que não venha a se consolidar no tempo na sua atual configuração (e sobre isso só se pode especular), não se pode negar que o discurso do direito ao esquecimento está de fato sendo mobilizado hoje (por partes e por órgãos jurisdicionais) para resolver problemas concretos, em circunstâncias, assim, mais do que suficientes para ensejar o prosseguimento do debate. Olhando para o outro lado da observação de Ost: se o esquecimento é perigoso, ele também é necessário.

O próprio desenvolvimento do discurso em torno do direito ao esquecimento parece evoluir com atenção à necessidade de absorver ou amortecer críticas.

Os casos concretos aqui trabalhados deixam claro que o direito ao esquecimento tem como um de seus elementos centrais a possibilidade de o interessado a quem os dados ou as informações se referem questionar o uso que é feito com tais informações ou dados, sobretudo em face do transcurso do tempo - conjugado, de toda sorte, com outros fatores, como o tipo, a finalidade e o contexto das informações, além de considerações sobre o papel que a pessoa desempenha na sociedade. Considerado amplamente (incluindo-se, portanto, por 
exemplo, números de CPF e de documentos de identidade, informações médicas, situações como as classificadas por Fleischer, dados creditícios, de consumo ou penais etc.), trata-se de um discurso que pode ensejar uma variedade de ações concretas, como o apagamento ou remoção de dados ou informações, a proibição de sua veiculação, a limitação (mesmo apriorística) de certos usos, a desindexação etc., oponíveis a variados atores, públicos ou privados e determinadas segundo diferentes comandos normativos (legislação, decisões judiciais etc.).

Essa amplitude de possíveis efeitos práticos, aliada à diversidade de situações e critérios a serem considerados, contribui para os receios que o "pomposo direito ao esquecimento" desperta. De maneira difusa, contudo, a ideia de esquecimento sempre existiu no direito, sob as mais variadas formas, algumas até já bem consolidadas na legislação e na prática jurídica, com ou sem maiores questionamentos (caso das prescrições civis e penais; das restrições de acesso a dados penais; das limitações temporais para arquivo e registro de dados sobre crédito e consumo; das anistias; da restrição de acesso a determinadas informações - para as quais é imposto um lapso temporal antes de serem liberadas etc.). Nas situações consolidadas, albergadas já pela legislação e pela jurisprudência, o esquecimento é tradicionalmente invocado não enquanto tal, mas enquanto instituto tipificado - argui-se a prescrição, a decadência, a ressocialização, a proteção de dados, a privacidade etc.

Se o esquecimento sempre existiu, o que mudou? Por que falar hoje em dia de um direito ao esquecimento, a respeito do qual de modo geral não se falava antes - ou pelo menos não despertava tanta atenção social? Ou por outro lado, se era invocado, era-o mediado por institutos, como a privacidade, a prescrição? Por que a tipificação (ainda que materialmente ampla) de um direito ao esquecimento? Trata-se de algo difícil de responder. Há todo um conjunto de transformações sociais que se associam e que possibilitam contingentemente a emergência de um direito ao esquecimento de grande alcance, mas com contornos próprios. As mudanças técnico-sociais, resgatadas no tópico anterior, a partir sobretudo de MayerSchönberger, Luhmann e Doneda, parecem ter contribuído significativamente para o surgimento de uma memória tão ampla e de fácil resgate, capaz de desencadear não mais somente efeitos positivos (como o aprendizado), mas também efeitos negativos, ensejadores de situações aflitivas e danos para as pessoas. Não que isso em si seja novidade (basta lembrar dos casos antigos envolvendo a privacidade e do próprio artigo de Warren e Brandeis). O que parece ter mudado foi a intensidade e a ampliação das possibilidades de mácula às pessoas. 
O desenvolvimento da internet e das novas mídias digitais, a migração, a adaptação ou o uso destas novas mídias pelas mídias tradicionais (televisão, revistas, rádio etc.), e o surgimento de novas ferramentas (como os motores de busca) contribuíram significativamente tanto para colocar o direito ao esquecimento na ordem do dia como para catalisar as discussões em torno de sua (nova) configuração.

Ao longo das últimas décadas, o fortalecimento do papel da mídia trouxe o direito ao esquecimento para as páginas de jornais e revistas, como meio de impedir que fatos pretéritos sejam ressuscitados de modo aleatório, com graves prejuízos para o envolvido. A internet, com a perenidade dos seus dados e a amplitude dos seus sistemas de pesquisa, catapultou a importância do direito ao esquecimento, colocando-o na ordem do dia das discussões jurídicas (SCHREIBER, 2014, p. 173).

Dado todo esse contexto, que mescla uma variedade de situações e uma grande velocidade nas comunicações e na circulação das informações, parece ter havido a necessidade de se desenvolver um mecanismo jurídico mais amplo de proteção das informações pessoais, para além das situações já prévia e materialmente definidas e tipificadas em dispositivos legais, de forma a abarcar, sobretudo em virtude de seu alcance, a atuação das mídias de massa no ambiente virtual. Embora admitam concepções amplas e variadas, densificáveis em variados institutos e usos, o direito à privacidade e o direito ao esquecimento possuem uma história de contínua reação aos efeitos negativos desencadeados pela atuação dos meios de comunicação de massa sobre as pessoas. Os casos Lebach (1 e 2), os Recursos Especiais no 1334097 e n 1335153 e o caso Google vs. Mario Costeja González demonstram concretamente essa afirmativa, colocando a questão da privacidade e do esquecimento frente a frente com a atuação da televisão e de motores de busca (estes, inclusive, com uma atuação que, para além de si própria, permite o resgate de informações variadas, inclusive de cunho pessoal veiculadas por outras mídias de massa). Os resultados distintos entre algumas dessas ações não afastam tal constatação. Apenas demonstram a necessidade de se construir diferenças à luz de cada situação concreta. A atuação dos meios de comunicação de massa atrai os discursos da liberdade de informação, de expressão e de imprensa, os quais passam a concorrer com o discurso do direito ao esquecimento ${ }^{76}$ -

\footnotetext{
${ }^{76}$ Costa relembra que "o Google, expressando os anseios dos buscadores da Internet, se mostra contrário à imposição de desindexação de conteúdo, como vem sendo determinado por diversas agências de proteção de dados, argumentando que tal medida atentaria contra a liberdade de informação e de expressão. Seria a página da web onde estão contidas as informações questionadas à qual se deve peticionar para retirar o conteúdo" (COSTA, 2013, p. 201).
} 
circunstância que desencadeia a necessidade de se construírem critérios diferenciadores para a incidência de cada um.

Nesse contexto de enquadramento do direito ao esquecimento vis-à-vis os meios de comunicação de massa, parece crescer a importância da crítica apresentada por Bucar (2013) à tentativa do STJ de limitar a aplicação do direito ao esquecimento apenas para o ambiente da mídia televisiva, apartando-o (pelo menos por enquanto) da internet - um ambiente diferenciado, segundo aquele tribunal, que pereniza as informações e que demandaria soluções específicas, técnicas, à luz de interesses que vão além dos Estadosnação ${ }^{77}$. A crítica é pertinente e merece coro. $\mathrm{O}$ ambiente virtual ou digital não é e nem pode ser um terreno sem balizamentos jurídicos ${ }^{78}$, mormente quando se considera que ele propicia uma propagação das informações numa escala muito superior em termos de quantidade, qualidade e velocidade que o tradicional ambiente analógico. Sendo o conteúdo o mesmo, não há justificativa para um tratamento jurídico distinto, aqui, em função do meio em que ocorre a comunicação. Tanto a televisão quanto o ambiente virtual da internet (sobretudo pelos motores de busca) devem ser tomados como meios de comunicação de massa que estão a liberar efeitos negativos semelhantes sobre os indivíduos, a partir do uso, reuso ou abuso de informações pessoais passadas ${ }^{79}$.

Partindo das tipicidades apresentadas por Mayer-Schönberger ${ }^{80}$, o discurso do direito ao esquecimento insere-se, assim, numa esteira de reforço da solução preconizada não por mudanças de comportamento (como a abstinência digital ou o ajuste cognitivo) ou pela tecnologia (como uma infraestrutura de direitos de privacidade ou uma contextualização perfeita), mas pelo direito à privacidade, compreendido este já não mais como um direito de estar só, mas como o direito de ter os dados pessoais protegidos, mantendo sobre eles um controle não egoístico, mas efetivamente relacional - ou seja, que reconhece que há outros interesses em jogo (como a liberdade de expressão). De toda forma, trata-se de um controle

\footnotetext{
${ }^{77}$ Martins (2014) também critica tal posicionamento do STJ.

${ }^{78}$ Tanto não é que o Brasil conta atualmente com o Marco Civil da Internet - Lei ${ }^{\circ} 12.965$, de 23 de abril de 2014 (BRASIL, 2014). Seu inteiro teor encontra-se reproduzido como anexo do presente trabalho.

${ }^{79} \mathrm{O}$ tema será objeto de maior detalhamento no próximo capítulo.

${ }^{80}$ Vide tópico anterior.
} 
que possibilita às pessoas uma margem de liberdade e de construção da própria personalidade frente à sociedade.

De acordo com Bucar (2013), a privacidade permitiria uma proteção com três ferramentas: o controle espacial, o controle contextual e o controle temporal. A ideia de controle espacial viabiliza à pessoa "conhecer, controlar, endereçar e interromper o fluxo de informações pessoais que dela tratam, possibilitando-lhe ter exata e prévia ciência do espaço informacional sobre o qual desenvolverá a sua personalidade" (BUCAR, 2013, p. 8). Trata-se, assim, do direito de controlar as próprias informações, de forma a assegurar a construção de uma esfera privada própria. O controle contextual, por sua vez, demanda que a informação apresente-se com exatidão, devendo, pois, "refletir, quando da divulgação, o contexto correto em que foi recebida" (BUCAR, 2013, p. 8). Já o controle temporal, âmbito dentro do qual, segundo o autor, o direito ao esquecimento estaria inserido, protege o indivíduo de ser lembrado por elementos do passado, após o transcurso de determinado período de tempo.

Em termos mais amplos, o direito ao esquecimento permite que a pessoa, no âmbito da concretização de sua plena autodeterminação informativa, exerça o controle da circulação de seus dados após determinado período, mediante supressão ou restrição, ainda que estes tenham por conteúdo informações passadas e verídicas acerca do interessado (BUCAR, 2013, p. 10).

$\mathrm{Na}$ esteira dos precedentes do STJ, o autor reconhece que o controle temporal de dados pessoais propiciado pelo direito ao esquecimento não se afigura absoluto, devendo ceder espaço - ainda que sem o consentimento (ou mesmo com a recusa) da pessoa a que as informações se referem - quando outros interesses se fizerem preponderantes. Com relação à história, por exemplo, não se trata de impedi-la, nem de se permitir um revisionismo, mas de colocar em discussão o "grau de relevância do papel da pessoa na constituição do evento", a ponto de se justificar ou não sua identificação (BUCAR, 2013, p. 12). Atingir esse equilíbrio entre a memória individual e a memória social certamente não é algo fácil ou livre de tensões.

Martinez (2014, p. 68 e ss) entende, de toda forma, que as perspectivas pública e privada não se excluem. A valorização de eventos históricos, a abertura de arquivos secretos, a rememoração de graves violações a direitos humanos etc. não impediriam, segundo ele, o movimento "privatista", baseado nos direitos de personalidade e na dignidade da pessoa humana, que protegeria o indivíduo da divulgação de informações descontextualizadas, sem utilidade pública, sem contemporaneidade, mesmo que verídicas. Ele chama inclusive a 
atenção para o fato de que a ideia de um direito ao esquecimento (em termos privados) teria berço justamente em países que enfrentaram no passado as agruras de regimes totalitários. Tal observação parece fazer sentido quando se tem em mente as discussões na União Europeia e o próprio caso Google vs. Mario Costeja González.

O direito ao esquecimento não se relaciona apenas com a possibilidade do direito de estar só, mas caracteriza-se pela vedação de se obrigar um indivíduo a conviver com pedaços de seu passado trazidos, imprudentemente, por atores sociais interessados apenas na exploração de fatos já consolidados e depositados no fundo da memória e do tempo, sem que haja qualquer motivo de fato razoável para a divulgação da informação (MARTINEZ, 2014, p. 81).

Trata-se de um direito voltado, assim, a impedir que a memória pessoal seja "revirada a todo instante, por força da vontade de terceiros" (MARTINEZ, 2014, p. 80). Ao contrário do entendimento de Bucar (que se filiaria ao pensamento predominante a respeito), Martinez não vê o direito ao esquecimento como uma vertente ou um aspecto do direito à privacidade, mas como um direito de personalidade novo e autônomo, com objeto jurídico de proteção distinto. Enquanto o direito à privacidade protegeria os dados pessoais contemporâneos, o direito ao esquecimento protegeria os dados pessoais pretéritos, “ou seja, a rememoração indevida de fatos passados e consolidados, que já não tenham qualquer utilidade (interesse público) ou atualidade" (MARTINEZ, 2014, p. 83). De toda sorte, radicando o direito ao esquecimento, em última instância, na dignidade da pessoa humana, Martinez (2014, p. 81-88) reconhece que sua aplicação termina por ensejar a proteção, ainda que indireta, dos outros direitos da personalidade já reconhecidos (nome, imagem, honra e a própria privacidade) ${ }^{81}$. Embora novos sentidos tenham sido agregados à ideia de privacidade $\mathrm{e}$ embora o direito ao esquecimento tenha surgido na sua esteira, parece que ele não se limita, com efeito, a ser apenas uma vertente do direito à privacidade, mas sim um direito que ganha ares de autonomia, mormente pelo fato de lidar especificamente com informações

${ }^{81}$ A propósito, é de se mencionar que a VI Jornada de Direito Civil, promovida pelo Centro de Estudos Judiciários - CEJ do Conselho da Justiça Federal - CJF aprovou o Enunciado $\mathrm{n}^{\mathrm{o}}$ 531, com o seguinte teor: "ENUNCIADO 531 - A tutela da dignidade da pessoa humana na sociedade da informação inclui o direito ao esquecimento. Artigo: 11 do Código Civil. Justificativa: Os danos provocados pelas novas tecnologias de informação vêm-se acumulando nos dias atuais. O direito ao esquecimento tem sua origem histórica no campo das condenações criminais. Surge como parcela importante do direito do ex-detento à ressocialização. Não atribui a ninguém o direito de apagar fatos ou reescrever a própria história, mas apenas assegura a possibilidade de discutir o uso que é dado aos fatos pretéritos, mais especificamente o modo e a finalidade com que são lembrados". Os enunciados aprovados encontram-se disponíveis para consulta em: $<$ http://www.cjf.jus.br/cjf/CEJ-Coedi/jornadas-de-direito-civil-enunciados-aprovados>. Acesso em: 15 fev. 2016. 
(verdadeiras) passadas, não atuais. O transcurso do tempo parece ser um fator primordial nesse sentido, assim como também o surgimento de novas tecnologias, as quais, apropriadas pelos meios de comunicação de massa, vão além da mera possibilidade de registro e de unificação de dados ou informações, ensejando mesmo o armazenamento, a recuperação e a difusão de informações em escala cada vez maior, mais fácil e mais barata - e, assim, abrindo espaço à criação de um contexto de rememoração perene de fatos passados no presente.

É interessante perceber que o direito ao esquecimento não impede as atividades de jornalismo e da imprensa. Não se trata de um discurso que postula a necessidade de autorização para que a imprensa possa vir a atuar - o que seria, de fato, censura. A propósito, veja-se que no caso Lebach a imprensa e a televisão fizeram ampla cobertura do fato criminoso à época de sua ocorrência. Os fatos de base dos casos discutidos no STJ - a chacina da Candelária e o assassinato de Aida Curi - também foram amplamente cobertos pela imprensa ao tempo em que ocorreram. Se considerado também, de sua sorte, o ambiente virtual, percebe-se que as informações circulam e as comunicações ocorrem, de regra, livre e publicamente, não havendo controle prévio a seu respeito. O que o Google indexa já é de conhecimento público. Não se está afirmando que conflitos nessas divulgações originais não possam existir. O próprio Ministro-relator dos Recursos Especiais no 1334097 e $n^{\circ} 1335153$ cuida de diferenciar, aliás, entre as situações já bastante discutidas na jurisprudência envolvendo publicações jornalísticas e direitos de personalidade, em contextos de ilicitude da informação e contemporaneidade da notícia, e a novel situação (a que o direito ao esquecimento se dirige) envolvendo informação lícita, porém não mais contemporânea ou - na linguagem do Tribunal de Justiça Europeu - que tenha se tornado inadequada, não pertinente, excessiva ou desatualizada ou que tenha sido armazenada por tempo superior ao necessário.

Conforme apontado nos votos condutores dos Recursos Especiais $n^{\circ} 1334097$ e $\mathrm{n}^{\mathrm{o}}$ 1335153, as liberdades de imprensa e de informação devem observar, como limite, porém, não somente a verossimilhança das informações, mas também a sua vida útil (ideia que dá relevância, assim, à passagem do tempo). E é justamente para evitar pretensões estigmatizantes que a possibilidade de se discutir a permanência ou não dessa utilidade se abre por meio do direito ao esquecimento. É de se notar, aliás, no tocante à atividade de imprensa, que, ao distinguir o tratamento de dados pessoais feito por um editor de página da internet daquele feito por um motor de busca no caso Google vs. Mario Costeja González, o Tribunal de Justiça Europeu advertiu para a possibilidade de o referido editor estar 
salvaguardado (do direito ao esquecimento) justamente pela liberdade jornalística - algo que não alcançaria, todavia, o tratamento de dados feito pelos motores de busca.

O uso das informações pessoais para fins históricos, estatísticos ou científicos pode inibir a incidência do direito ao esquecimento - ou, pelo menos, modulá-lo, afastando medidas mais rigorosas (como o apagamento geral dos dados) e enfatizando soluções mais relativas (por exemplo, tornando mais restrito e contextualizado o acesso às informações; tornando anônimos os dados, de forma a não se permitir a identificação pessoal dos envolvidos; ou seja, estabelecendo-se certas garantias que minimizem as eventuais ofensas aos direitos fundamentais das pessoas envolvidas).

A respeito, é interessante notar que a execução da decisão do Tribunal de Justiça Europeu não está a ensejar um apagamento dos dados por parte do Google (algo que, de toda forma, ele nem poderia tecnicamente fazer), mas sim uma desindexação com base no nome das pessoas e apenas de determinados links (URLs) especificamente identificados. Isso significa que a informação continua disponível na internet, podendo ser localizada diretamente no âmbito do site em que hospedada (desde que se conheça tal localização, evidentemente) e mesmo por meio de pesquisas no Google, todavia a partir de critérios de busca aptos a resgatar a página não pelo nome pessoal específico que contém (e que foi desindexado enquanto critério de pesquisa), mas por outros critérios de busca que levam à mesma página. Tal solução dificulta a localização de uma informação em virtude do nome de uma determinada pessoa, mas não impede a sua localização a partir de outros critérios relevantes. E uma vez que a página é achada por outros critérios, o nome figurará no conteúdo da comunicação e a pessoa terminará por ser identificada. Trata-se, em suma, de um mecanismo que, ao restringir o acesso à determinada informação em função pura e simplesmente do indivíduo a que ela se refere, termina por afastar uma busca ou uma difusão de informações sem critérios ou por pura "curiosidade sobre a vida de uma pessoa" (curiosidade esta que pode causar danos), e por ensejar a observância de critérios e propósitos mais contextualizados e específicos por parte daquele que procura a informação. De toda forma, páginas não desindexadas continuarão a ser exibidas nos resultados de buscas feitas pelo nome da respectiva pessoa tratada. 
Se no tocante aos motores de busca ocorre uma desindexação, no caso da televisão os casos concretos apontam para a necessidade de não se dar um tratamento sensacionalista ou estigmatizante à situação retratada, devendo-se, assim, dentre outros cuidados necessários à devida contextualização dos fatos, evitar a exibição do nome e da imagem de determinadas pessoas. É justamente o ponto dos casos Lebach-1 e Lebach-2. Na esteira da observação de Sarlet (2015) acima referida, o direito ao esquecimento não impede tratamentos posteriores das informações, nem tampouco impede a opinião pública de ser novamente confrontada com os fatos - sobretudo criminosos. Mas ele possibilita justamente o questionamento acerca de como os eventos são resgatados, afigurando-se importante verificar, a respeito, "o grau de relevância do papel da pessoa na constituição do evento" (BUCAR, 2013, p. 12). Desta forma, “[m]esmo participando ativa ou passivamente, o que se busca é a verificação se aquele fato, caracterizado como evento histórico de determinado setor, pode ser novamente propagado com a necessária identificação de suas personagens" (BUCAR, 2013, p. 12).

Não se trata de algo fácil. Veja-se que nos Recursos Especiais no 1334097 e no 1335153, o STJ reconhece (abstratamente) a possibilidade do direito ao esquecimento não só para condenados que cumpriram pena e para os absolvidos que se envolveram em processos criminais, mas também para as vítimas de crimes e seus familiares. Em quaisquer casos, porém, a corte superior aponta para a necessidade de se verificar a historicidade dos fatos narrados. No caso da Chacina da Candelária (RE 1334097 - apreciado à luz da condição específica da pessoa do autor da ação frente aos fatos), o STJ entendeu que o fato histórico poderia ser recontado sem a exposição do nome e da imagem do autor. Já no caso Aida Curi (RE 1335153 - apreciado à luz da postulação feita pelos irmãos vivos da vítima), o STJ concluiu que não seria possível recontar o caso Aida Curi sem Aida Curi - sua figura teria se tornado elemento indissociável do delito, o qual, inclusive, não teria sido alvo de uma historicidade artificiosamente criada, ou seja, à época do ocorrido a cobertura da mídia não teria sido abusiva, exploratória ou populista. Os fatos relativos ao caso seriam discutidos publicamente até hoje, inclusive academicamente.

A divergência que existiu no julgamento do caso Aida Curi (e que restou vencida) chamou a atenção, dentre outros pontos, contudo, para o fato de o programa ter retratado uma pessoa que não era personagem histórica, famosa, notória ou política, mas comum da cidade 
do Rio de Janeiro e que teria sido apresentada por meio de uma foto em que aparecia morta, ensanguentada e abraçada por um dos irmãos.

Salta aos olhos, portanto, o grande desafio prático de se distinguir, conforme apontado por Rodrigues Junior (2013d), entre elementos históricos e a proteção da intimidade (seja de pessoas vivas ou mortas), ou mesmo para avaliar o papel desempenhado pela pessoa na vida pública ${ }^{82}$. Uma pessoa comum, um crime histórico? Para além do caso Aida Curi (e sem entrar no seu mérito quanto a isso), sim, é possível. E - é importante destacar -, embora a forte lembrança ("historicidade") do fato possa estar relacionada com a maneira com a qual a mídia veio a cobrir os eventos à época em que ocorreram, não se pode dizer que isso seja um elemento de corte a afirmar ou negar o caráter histórico de um fato. Faz-se história com o passado, mas o passado, a memória e os arquivos não falam por si só: dependem, na verdade, de perguntas feitas no presente - e cuja necessidade pode estar radicada justamente na

\footnotetext{
${ }^{82}$ Afigura-se oportuno destacar que a tensão entre a necessidade de se produzir a história e de se preservar a privacidade ou intimidade das pessoas não surgiu com o discurso do direito ao esquecimento que ora se delineia. No Brasil, a Lei $\mathrm{n}^{\circ} 8.159$, de 8 de janeiro de 1991 (BRASIL, 1991), ao cuidar do acesso e do sigilo dos documentos públicos, estipulava serem originariamente sigilosos os documentos relativos à intimidade, à vida privada, à honra e à imagem das pessoas, ficando o acesso aos documentos sigilosos referentes à honra e à imagem restrito por um prazo máximo de 100 (cem anos), a contar de sua produção (art. 23, parágrafos $1^{\circ}$ e $3^{\circ}$ ). Posteriormente, o artigo $7^{\circ}$ da Lei $\mathrm{n}^{\circ} 11.111$, de 5 de maio de 2005 (BRASIL, 2005), estabeleceu que os documentos públicos que contivessem informações relacionadas à intimidade, à vida privada, à honra e à imagem de pessoas, e que fossem ou viessem a ser de livre acesso, poderiam ser franqueados por meio de certidão ou cópia que expurgasse ou ocultasse justamente a parte sobre a qual recaía a inviolabilidade da intimidade, da vida privada, da honra e da imagem das pessoas. As informações expurgadas ou ocultadas seriam acessadas, no curso do prazo máximo de 100 (cem) anos, apenas pela pessoa diretamente interessada ou, em se tratando de morto ou ausente, pelo cônjuge, ascendentes ou descendentes. Tanto o destacado artigo 23 (mais os artigos 22 e 24) da Lei $\mathrm{n}^{\circ} 8.159$, de 1991, quanto a própria Lei $\mathrm{n}^{\circ} 11.111$, de 2005 (esta, na íntegra), foram revogados pela Lei $\mathrm{n}^{\circ} 11.527$, de 18 de novembro de 2011 (Lei de Acesso à Informação). A Lei de Acesso à Informação - LAI (BRASIL, 2011), de sua sorte, estabeleceu que "[o] tratamento das informações pessoais deve ser feito de forma transparente e com respeito à intimidade, vida privada, honra e imagem das pessoas, bem como às liberdades e garantias individuais" (art. 31, caput). As informações pessoais referentes à intimidade, vida privada, honra e imagem ficam restritas, independentemente de classificação de sigilo, pelo prazo máximo de 100 (cem) anos, a contar da data de sua produção, a agentes públicos legalmente autorizados e à pessoa a que elas se referirem, podendo, contudo, "ter autorizada sua divulgação ou acesso por terceiros diante de previsão legal ou consentimento expresso da pessoa a que elas se referirem" (art. 31, parágrafo $1^{\circ}$, incisos I e II). O consentimento em questão, contudo, não será exigido quando as informações se fizerem necessárias, dentre outras hipóteses, para "realização de estatísticas e pesquisas científicas de evidente interesse público ou geral, previstos em lei, sendo vedada a identificação da pessoa a que as informações se referirem"; "defesa de direitos humanos"; ou "proteção do interesse público e geral preponderante" (art. 31, parágrafo $3^{\circ}$, incisos II, IV, V). De forma bastante inovadora, a LAI dispôs ainda que "[a] restrição de acesso à informação relativa à vida privada, honra e imagem de pessoa não poderá ser invocada (...) em ações voltadas para a recuperação de fatos históricos de maior relevância" (art. 31, parágrafo $4^{\circ}$ ). De toda sorte, "[a]quele que obtiver acesso às informações de que trata este artigo será responsabilizado por seu uso indevido" (art. 31, parágrafo $2^{\circ}$ ). Do marco normativo acima traçado percebe-se a complexidade do assunto: da mesma forma que se afigura complicado definir elementos como o papel de uma pessoa na vida pública, a desatualização ou irrelevância de uma informação, ou quem teria legitimidade para apreciar tais considerações, igualmente desafiadora se apresenta a disputa interpretativa em torno de critérios envolvendo, por exemplo, a "proteção do interesse público e geral preponderante" ou "fatos históricos de maior relevância".
} 
demanda pela lembrança de fatos "esquecidos", não devidamente recordados ou não famosos, os quais precisam de luzes para deixar explícitas algumas distinções caras às demandas do presente. Tais distinções, de sua sorte, podem servir para fazer oscilar o futuro, abrindo-o para novas possibilidades (embora se saiba, de toda forma, que o futuro remanesce imprevisível e indeterminado) (LUHMANN, 2007, p. 460 e ss). Nesse sentido, o passado encontra-se, portanto, tão aberto quanto o futuro.

Para o historiador, o documento não está simplesmente dado, como a ideia de rastro deixado poderia sugerir. Ele é procurado e encontrado. Bem mais que isso, ele é circunscrito, e nesse sentido constituído, instituído documento, pelo questionamento. Para um historiador, tudo pode tornar-se documento, obviamente, os cacos das escavações arqueológicas e outros vestígios, mas, de modo mais marcante, as informações tão diversas quanto tabelas e curvas de preços, registros paroquiais, testamentos, bancos de dados estatísticos, etc. Torna-se assim documento tudo o que pode ser interrogado por um historiador com a ideia de nele encontrar uma informação sobre o passado (RICOEUR, 2007, p. 189).

Considerando-se as dificuldades em se prever quando uma informação poderá adquirir ou readquirir relevância, Sankievicz (2015) sugere que as decisões sobre o direito ao esquecimento - que, no Brasil, conforme o Marco Civil da Internet, dependem de decisão judicial $^{83}$ - possuam caráter rebus sic stantibus, ou seja, valeriam enquanto mantidas as mesmas condições que determinaram a sua prolatação. Mudando-se o estado de coisas, nova apreciação do caso poderia ocorrer e nova decisão poderia ser prolatada a respeito. Assim, por exemplo, um link desindexado poderia vir a ser novamente indexado caso o indivíduo nele referido deixasse de ser um anônimo e se tornasse uma figura de destaque na vida pública. Afinal, a par de finalidades históricas, científicas e estatísticas, o papel desempenhado pela pessoa na vida em sociedade afigura-se também como um critério fundamental para a aferição da incidência ou não do direito ao esquecimento. Pessoas públicas possuem de regra um nível de exposição maior - e, portanto, níveis de privacidade e de esquecimento tendencialmente menores $^{84}$.

\footnotetext{
${ }^{83}$ Vide a Lei no 12.965 , de 23 de abril de 2014 (BRASIL, 2014), que segue anexa ao presente trabalho.

${ }^{84}$ A discussão em torno do direito ao esquecimento ainda não foi apreciada pelo Supremo Tribunal Federal. Contudo, no julgamento da Ação Direta de Inconstitucionalidade no 4815/DF (BRASIL, 2016), que discutiu a necessidade ou não de autorização prévia para publicação de biografias, o STF teve oportunidade de debater muitos dos temas caros à discussão em torno do direito ao esquecimento, como privacidade, liberdade de expressão, censura, papel das pessoas na vida pública (este, um aspecto crucial para a publicação de uma
} 
biografia), maior ou menor grau de privacidade, relação da biografia com a história etc. São citados, inclusive, julgados típicos do direito ao esquecimento, como o caso Lebach. Conforme exposto no Acórdão, a corte julgou procedente o pedido formulado na ação para, dando interpretação conforme à Constituição aos artigos 20 e 21 do Código Civil, sem redução de texto, "declarar inexigível o consentimento de pessoa biografada relativamente a obras biográficas literárias ou audiovisuais, sendo por igual desnecessária autorização de pessoas retratadas como coadjuvantes (ou de seus familiares, em caso de pessoas falecidas)". A consulta ao inteiro teor do julgamento demonstra que houve discussão e preocupação no âmbito da corte em adotar uma posição minimalista, no sentido de se afirmar a desnecessidade de autorização prévia para publicação de biografias, mas de não avançar a ponto de dizer que a única forma de intervenção possível do Judiciário em casos de biografias violadoras da privacidade, da intimidade, honra ou imagem seria a posteriori, para se garantir indenização. Intervenções como as do Ministro Gilmar Mendes e do Ministro Ricardo Lewandowski procuraram deixar claro que a indenização é uma das formas de intervenção (in casu, reparadora), que não exclui outras (como a própria possibilidade de a publicação da obra ser sustada, de haver apreensão cautelar - medidas possíveis, embora em situações excepcionalíssimas, a serem analisadas concretamente, caso a caso). O Ministro Ricardo Lewandowski chegou a destacar a complexidade do tema, mormente quando se considera o ambiente da internet, no qual são publicadas "biografias ofensivas, apócrifas, sem autores, não autorizadas, em países onde a própria jurisdição brasileira não alcança. Então, o problema hoje é extremamente complexo e é preciso que nós tenhamos meios para coibir estes abusos que, infelizmente, existem no mundo real" (BRASIL, 2016). A ementa do julgado dispôs o seguinte: "EMENTA: AÇÃO DIRETA DE INCONSTITUCIONALIDADE. ARTS. 20 E 21 DA LEI N. 10.406/2002 (CÓDIGO CIVIL). PRELIMINAR DE ILEGITIMIDADE ATIVA REJEITADA. REQUISITOS LEGAIS OBSERVADOS. MÉRITO: APARENTE CONFLITO ENTRE PRINCÍPIOS CONSTITUCIONAIS: LIBERDADE DE EXPRESSÃO, DE INFORMAÇÃO, ARTÍSTICA E CULTURAL, INDEPENDENTE DE CENSURA OU AUTORIZAÇÃO PRÉVIA (ART. $5^{\circ}$ INCS. IV, IX, XIV; 220, $\S \S 1^{\circ} \mathrm{E}^{\circ}$ ) $\mathrm{E}$ INVIOLABILIDADE DA INTIMIDADE, VIDA PRIVADA, HONRA E IMAGEM DAS PESSOAS (ART. $5^{\circ}$, INC. X). ADOÇÃO DE CRITÉRIO DA PONDERAÇÃO PARA INTERPRETAÇÃO DE PRINCÍPIO CONSTITUCIONAL. PROIBIÇÃO DE CENSURA (ESTATAL OU PARTICULAR). GARANTIA CONSTITUCIONAL DE INDENIZAÇÃO E DE DIREITO DE RESPOSTA. AÇÃO DIRETA JULGADA PROCEDENTE PARA DAR INTERPRETAÇÃO CONFORME À CONSTITUIÇÃO AOS ARTS. 20 E 21 DO CÓDIGO CIVIL, SEM REDUÇÃO DE TEXTO. 1. A Associação Nacional dos Editores de Livros - Anel congrega a classe dos editores, considerados, para fins estatutários, a pessoa natural ou jurídica à qual se atribui o direito de reprodução de obra literária, artística ou científica, podendo publicá-la e divulgá-la. A correlação entre o conteúdo da norma impugnada e os objetivos da Autora preenche o requisito de pertinência temática e a presença de seus associados em nove Estados da Federação comprova sua representação nacional, nos termos da jurisprudência deste Supremo Tribunal. Preliminar de ilegitimidade ativa rejeitada. 2. O objeto da presente ação restringe-se à interpretação dos arts. 20 e 21 do Código Civil relativas à divulgação de escritos, à transmissão da palavra, à produção, publicação, exposição ou utilização da imagem de pessoa biografada. 3. A Constituição do Brasil proíbe qualquer censura. $\mathrm{O}$ exercício do direito à liberdade de expressão não pode ser cerceada pelo Estado ou por particular. 4. O direito de informação, constitucionalmente garantido, contém a liberdade de informar, de se informar e de ser informado. O primeiro refere-se à formação da opinião pública, considerado cada qual dos cidadãos que pode receber livremente dados sobre assuntos de interesse da coletividade e sobre as pessoas cujas ações, público-estatais ou público-sociais, interferem em sua esfera do acervo do direito de saber, de aprender sobre temas relacionados a suas legítimas cogitações. 5. Biografia é história. A vida não se desenvolve apenas a partir da soleira da porta de casa. 6. Autorização prévia para biografia constitui censura prévia particular. O recolhimento de obras é censura judicial, a substituir a administrativa. O risco é próprio do viver. Erros corrigem-se segundo o direito, não se coartando liberdades conquistadas. A reparação de danos e o direito de resposta devem ser exercidos nos termos da lei. 7. A liberdade é constitucionalmente garantida, não se podendo anular por outra norma constitucional (inc. IV do art. 60), menos ainda por norma de hierarquia inferior (lei civil), ainda que sob o argumento de se estar a resguardar e proteger outro direito constitucionalmente assegurado, qual seja, o da inviolabilidade do direito à intimidade, à privacidade, à honra e à imagem. 8. Para a coexistência das normas constitucionais dos incs. IV, IX e X do art. $5^{\circ}$, há de se acolher o balanceamento de direitos, conjugando-se o direito às liberdades com a inviolabilidade da intimidade, da privacidade, da honra e da imagem da pessoa biografada e daqueles que pretendem elaborar as biografias. 9. Ação direta julgada procedente para dar interpretação conforme à Constituição aos arts. 20 e 21 do Código Civil, sem redução de texto, para, em consonância com os direitos fundamentais à liberdade de pensamento e de sua expressão, de criação artística, produção científica, declarar inexigível autorização de pessoa biografada relativamente a obras biográficas literárias ou audiovisuais, sendo também desnecessária autorização de pessoas retratadas como coadjuvantes (ou de seus familiares, em caso de pessoas falecidas ou ausentes)" (BRASIL, 2016). 
O debate em torno do direito ao esquecimento precisa continuar e se aprofundar, de forma a gerar contornos mais refinados. Para isso, a divulgação de dados empíricos se torna importante, sobretudo por parte de empresas que gerenciam motores de busca. Considerando que tais empresas possuem interesses econômicos nítidos no tratamento de informações, que qualquer limitação nas possibilidades de efetuar tais tratamentos afeta diretamente suas atividades e que, pelo menos da União Europeia, elas são responsáveis pela análise, julgamento e execução dos pedidos de desindexação, apresenta-se mais do que crucial a divulgação de dados consistentes sobre os tipos de pessoas que solicitam a desindexação, as situações concretas que subjazem aos pedidos, os tipos de informações envolvidas etc. A ausência de dados como esses no debate deixa a discussão nebulosa e tendencialmente marcada por exemplos controversos e sensacionalistas, verdadeiras situações-limite, divulgadas seletivamente por partes interessadas (mormente a mídia de uma maneira geral).

A propósito, aliás, deve-se apontar que Tippmann e Powles (2015), escrevendo para o jornal britânico The Guardian, destacaram que dados acidentalmente revelados pelo Google informam que mais de $95 \%$ dos pedidos de desindexação direcionados à empresa na União Europeia provêm de cidadãos comuns ("everyday members of the public") em busca de proteger informações pessoais e privadas - não de criminosos, políticos e figuras públicas (responsáveis por menos de $5 \%$ dos então quase 220.000 pedidos feitos). Os dados referidos (parciais e atualizados até março de 2015) demonstram, segundo as autoras, que a ênfase da discussão em torno do direito ao esquecimento tem recaído sobre informações seletivas referentes a exemplos dos casos mais espantosos liberados pelo Google e divulgados pela mídia, não se dando a devida atenção para o teor da maioria dos pedidos efetuados. A reportagem indica ainda que, descontados dados pendentes de processamento, quase a metade (48\%) dos pedidos envolvendo dados privados ou pessoais são deferidos, número que cai para $46 \%$ quando se considera o total de pedidos efetuados no período.

De 218.320 pedidos de remoção de links entre 29 de maio de 2014 e 23 de março de 2015, 101.461 (46\%) foram com sucesso desindexados de buscas por nomes individuais. Destes, 99.569 envolvem “informação privada ou pessoal”.

Somente 1.892 pedidos - menos de $1 \%$ do total global - tiveram sucesso relativamente aos quatro tipos de assuntos remanescentes identificados dentro do código-fonte do Google: “crime sério" (728 pedidos), "figura pública” (454), "político" (534) ou "proteção de criança" (176) - presumivelmente porque eles 
dizem respeito a vítimas, testemunhas incidentais, condenações passadas ou a vidas privadas de pessoas públicas (TIPPMANN e POWLES, 2015, tradução nossa).

Embora relevantes, chamando a atenção para uma efetiva mobilização do direito ao esquecimento por pessoas comuns, os dados afiguram-se ainda bastante gerais e incompletos. Por exemplo, se a maioria dos pedidos (mais de 95\%) diz respeito a dados privados de pessoas comuns, por qual motivo a taxa de deferimento de tais pedidos (descontadas as análises pendentes) cai para quase a metade (48\%)? Doutro lado, a reportagem indica ainda haver uma variação entre países no tocante às taxas de deferimento dos pedidos envolvendo informações privadas: enquanto na França e na Alemanha mais da metade dos pedidos feitos tiveram sucesso na desindexação, no Reino Unido e na Itália apenas um terço obteve o mesmo desiderato. "Essas diferenças podem ser atribuídas aos pedidos em si, ao resultado de variações culturais e jurídicas entre países, ao impacto das autoridades de proteção de dados ou porque o Google não sincroniza os critérios de decisão e processamento entre países" (TIPPMAN e POWLES, 2015). Tudo isso só mostra que uma maior transparência e detalhamento na divulgação desses dados se faz necessária. 


\section{CAPÍTULO 3 - DIREITO AO ESQUECIMENTO COMO REAÇÃO AOS MEIOS DE COMUNICAÇÃO DE MASSA}

\subsection{Sobre os meios de comunicação de massa ${ }^{85}$ e as novas mídias digitais}

Segundo Luhmann, os meios de difusão, cuja evolução parte da invenção da escrita até os atuais meios eletrônicos (2007, p. 242), promovem uma redundância social da comunicação, determinando e ampliando o círculo de receptores de uma comunicação. "Na medida em que se difunde a mesma informação, a informação se transforma em redundância" - e "a redundância faz com que a informação se exceda" (LUHMANN, 2007, p. 155, tradução nossa).

Embora o surgimento da escrita tenha sido um fator importante para difusão da comunicação para além da interação entre presentes - alcançando, portanto, receptores

${ }^{85}$ Die Realität der Massen Medien é o título original em alemão do livro de Luhmann sobre dos meios de comunicação de massa. Tal obra restou traduzida em espanhol como La realidad de los medios de masas (LUHMANN, 2000) e em português como A realidade dos meios de comunicação (LUHMANN, 2005b). A tradução em espanhol foi feita por Javier Torres Nafarrate - também responsável por verter ao espanhol outras obras de Luhmann, como a aqui também trabalhada La sociedad de la sociedad (LUHMANN, 2007), ou, no original, Die Gesellschaft der Gesellschaft. A tradução para o português ficou a cargo de Ciro Marcondes Filho. O próprio Ciro Marcondes Filho, ao assinar o verbete "mass media" para o Dicionário da Comunicação, destaca que o referido termo ("mass media") tem origem anglo-saxã e data do início do Século XX, sendo representativo do "conjunto dos meios de comunicação de massa, especialmente as cadeias suprarregionais de difusão, inicialmente em rádio e nos veículos impressos, jornais e revistas, que passaram a ter tiragens em alta escala" (MARCONDES FILHO, 2009, p. 317). Ele aponta, ainda, que a forma original "mass media" apresenta-se ambígua, "pois supõe tanto a produção em massa de material informativo ou de entretenimento como seu consumo maciço ou "massivo"” (MARCONDES FILHO, 2009, p. 317). A tradução em português como "comunicação de massa" faria perder, contudo, ambos os sentidos, já que para retratá-los dever-se-ia falar de meios de comunicação em massa ou para massas - "mas jamais de massas, já que as massas não participam do processo de produção da mesma, mas de seu consumo" (MARCONDES FILHO, 2009, p. 317). Sem esquecer de tais observações, adota-se, de regra, aqui, contudo, a expressão "meios de comunicação de massa" como tradução para "mass media", em razão de seu uso comumente consagrado, como forma de facilitar a inteligibilidade e fluência do texto e tendo em vista os objetivos do presente trabalho - que cuida não de debater os meios de comunicação de massa em si, mas de marcar alguns aspectos importantes a seu respeito, tendo em vista o discurso do direito ao esquecimento. Usamos também, pelas mesmas razões e considerados os mesmos fins, termos como mídias de massa, mídias digitais, embora saibamos que Ciro Marcondes Filho, ao cuidar do verbete "media" no referido Dicionário da Comunicação, também critica o neologismo "mídia", preferindo a forma "media", que é plural de "medium". Segundo o apontado autor, os media (redução da forma original mass media) configuram "o conjunto dos meios de comunicação que produzem em massa e veiculam para uma massa indistinta de público" (MARCONDES FILHO, 2009, p. 324). De outro lado, as traduções em espanhol e em português da obra de Luhmann Die Realität der Massen Medien possuem diferenças textuais tais que, à luz dos elementos que neste trabalho se pretende marcar, terminam por recomendar o uso de ambas, seja de forma cotejada, seja de forma individualizada. 
ausentes no tempo e no espaço e possibilitando a ilusão da simultaneidade daquilo que não é simultâneo (LUHMANN, 2007, p. 205) -, apenas com a invenção da impressão e dos meios de massa modernos é que a redundância social efetivamente se tornou anônima (LUHMANN, 2007, p. 155).

No processo de diferenciação dos meios de massa, a conquista decisiva deve ter sido a descoberta das tecnologias expansivas da comunicação. Essas tecnologias não apenas poupam que haja comunicação entre presentes, como expressamente a excluem para a comunicação específica dos mass media. A escrita não foi capaz de produzir, por si só, esse efeito, já que originalmente estava pensada como apoio da comunicação oral primitiva. A exclusão da interação entre os presentes resultou como produto da impressão, que multiplicou o acervo de materiais escritos com tamanha força que fez com que os efeitos produzidos por todos os participantes já não fossem nem efetivos, nem visíveis. Em todo caso, o círculo de clientes ou consumidores se faz notar pelo seu peso quantitativo, (...) mas sem que se possa reagir em sentido contrário.

O quantum da presença pode ser interpretado e descrito, mas não pode estabelecer comunicação com os presentes. Evidentemente, a comunicação oral permanece como reação à comunicação impressa ou emitida, contudo, o êxito da comunicação planejada já não depende dela (LUHMANN, 2000, p. 23-24, tradução nossa, grifos do original).

O fato de os receptores da comunicação não serem mais visíveis, aparecendo “apenas" por meios quantitativos (índices de vendas, taxas de audiência etc.), não exclui, segundo o próprio Luhmann, comunicações posteriores desses destinatários - seja em forma oral ou escrita, presencial ou não, por exemplo, como ligações telefônicas que vão ao ar, oriundas de ouvintes de uma rádio, ou como o endereçamento de cartas às redações. Ele destaca, porém, que tais possibilidades são incorporadas à dinâmica autônoma do próprio sistema dos meios de comunicação de massa, servindo à sua reprodução e não ao seu contato com o entorno que o cerca. O ponto decisivo, segundo Luhmann, é o fato de que tais comunicações não ocorrem no modo específico da comunicação de massas (LUHMANN, 2000, p. 23-24, sobretudo notas de rodapé $n^{\circ} 4$ e n ${ }^{\circ} 5$ ).

Por meios de comunicação de massas deve-se entender todas aquelas instituições da sociedade que se servem de meios técnicos de reprodução para propagar ou difundir a informação - incluindo, portanto, sobretudo, livros, revistas e jornais (no tocante aos meios impressos), mas também reproduções fotográficas ou eletrônicas de todos os tipos, na medida 
em que sua produção ocorra em grande quantidade e esteja dirigida a um público indeterminado (LUHMANN, 2000, p. 2; 2005b, p. 16). A difusão da comunicação que se realiza por meio do rádio também entra na definição quando ela esteja acessível ao público, mas não na sua forma de conectar participantes individuais numa conversa telefônica. Já conferências, representações teatrais, exposições, concertos, ou seja, eventos que permitem a formação de um espaço público que dá acesso à comunicação, não entram na ideia de meios de comunicação de massas - embora os filmes ou disquetes que propiciam o conhecimento amplo e a divulgação de tais representações sejam considerados como tais. Tais delimitações, embora pareçam arbitrárias, carregam por detrás de si, porém, a ideia de que "unicamente o produto obtido maquinalmente, em sua qualidade de portador da comunicação - e por conseguinte, não a escrita enquanto tal - foi o que conduziu à diferenciação de um sistema especial, denominado meios de comunicação de massas" (LUHMANN, 2000, p. 3, tradução nossa). A tecnologia funcionou, portanto, apenas como um meio que possibilitou a construção de formas que, distintas do meio em si, passaram a ligar operações comunicativas e a tornar possível a diferenciação e a clausura do sistema surgido. De toda forma, o ponto decisivo para todas as situações reside no fato de não haver interação entre emissor e receptor - algo que, como visto, apresenta exceções, mas não a todos os participantes e nem a ponto de invalidar a necessidade e a condicionante da interposição da técnica enquanto princípio que rompe com o contato interativo direto ou imediato (LUHMANN, 2000, p. 3).

O rompimento desse contato termina por possibilitar graus elevados de liberdade na comunicação e, assim, "um excedente de possibilidades comunicacionais que só pode ser controlado dentro do sistema por meio da auto-organização e de reconstruções da realidade que lhe são próprias" (LUHMANN, 2005b, p. 17). Nessa dinâmica, tomam parte dois seletores que não podem ser coordenados de forma centralizada: a disposição para emitir comunicações e o interesse de se conectar a ela. Sob tal circunstância, as organizações responsáveis pela comunicação dos meios de massas dependem de suposições no tocante às exigências (desmedidas) do público e da aceitação de tais exigências - um contexto, assim, que desencadeia a necessidade de estandardização da comunicação, a necessidade de os meios de massa diferenciarem seus programas, o reconhecimento de que a oferta comunicativa não tem como se ajustar ou se moldar a cada indivíduo em particular e que, em função disso, a cada um abre-se a possibilidade de extrair da comunicação produzida em massa aquilo que lhe convém ou que acredita precisar saber (LUHMANN, 2000, p. 3-4; 2005b, p. 17-18). 
Luhmann fala da realidade dos meios de comunicação de massa num duplo sentido. De forma resumida, pode-se dizer que, num primeiro viés, a realidade dos meios de comunicação de massa consiste em suas próprias operações, no fato de que elas realmente ocorrem e são observáveis - "imprime-se, difunde-se, lê-se, captam-se emissões" (LUHMANN, 2000, p. 4, tradução nossa). Ou seja, uma realidade que consiste nas comunicações contínuas que realmente têm lugar no âmbito do sistema e que permitem com que ele se reproduza a si próprio e se diferencie de seu entorno. Já no segundo sentido, fala-se da realidade dos meios de comunicação de massa em relação "àquilo que para eles ou por meio deles aparece como realidade para outros” (LUHMANN, 2005b, p. 20, grifos do original) ou, por outras palavras, "o que aparece como realidade para eles ou aquilo que os outros têm por realidade porque o tomaram dos meios de comunicação" (LUHMANN, 2000, p. 6, tradução nossa, grifos do original).

Dizer que os meios de comunicação de massa constituem um (sub)sistema social significa afirmar que eles configuram uma unidade que se assenta numa diferença, qual seja: a diferença entre sistema e meio (ou entorno, ambiente externo). Colocando em termos gerais, o sistema diferencia-se do meio pelo fato de fechar-se operativamente, de maneira a fixar por si mesmo seus limites, a partir de operações exclusivas que só ocorrem no seu lado interno e que o distinguem do ambiente que o circunda (LUHMANN, 2011, p. 101-102).

No âmbito social, não existe uma multiplicidade de alternativas de modo a escolher, entre elas, a operação que defina o social. A comunicação é o único fenômeno que cumpre com os requisitos: um sistema social surge quando a comunicação desenvolve mais comunicação, a partir da própria comunicação (LUHMANN, 2011, p. 90).

A sociedade é, pois, formada de comunicação. Não há comunicação fora da sociedade. A comunicação configura a sempre e única operação básica que designa o sistema social e que o (re)produz recursivamente, ou seja, mediante a concatenação seletiva no tempo de operações do mesmo tipo - comunicação enseja comunicação, que enseja comunicação e daí por diante (LUHMANN, 2011, p. 89-90). A comunicação é a operação genuinamente social porque embora pressuponha o concurso de incontáveis sistemas de consciência (ou psíquicos) para ocorrer - e justamente por isso -, não pode ser atribuída a nenhuma consciência isolada para se perfazer. De outro lado, "ela é social, porque de modo algum pode ser produzida uma consciência comum coletiva, isto é, não se pode chegar ao consenso, no 
sentido de um acordo total; e, no entanto, a comunicação funciona" (LUHMANN, 2011, p. 91).

Considerada a sociedade como um todo, ou seja, enquanto sistema social mais abrangente, não há, de fato, comunicação fora dela, ou seja, no seu ambiente. Tal circunstância não nega, contudo, a imprescindível ocorrência de comunicações dentro da sociedade sobre seus ambientes psíquico, orgânico e físico-químico (NEVES, 2008, p. 66). Por outro lado, quando se toma em consideração não mais a sociedade como um todo, mas seus subsistemas sociais ou sistemas parciais - que possuem, todos, a comunicação como unidade elementar comum e que, portanto, desenvolvem comunicação não somente sobre o seu ambiente, mas também com ele -, surge a indagação que busca saber quais comunicações pertencem a um determinado subsistema e quais ocorrem no seu ambiente externo.

Por meio de um código sistêmico próprio, estruturado binariamente entre um valor negativo e um valor positivo específico, as unidades elementares do sistema são reproduzidas internamente e distinguidas claramente das comunicações exteriores. Mas os códigos tornam-se formas vazias caso não sejam combinados com programas e critérios (NEVES, 2008, p. 67).

O código apresenta-se como uma forma de dois lados, que fixa, portanto, um valor positivo e um valor negativo, excluindo-se uma terceira possibilidade. Ele não representa um princípio, uma meta, uma tomada de posição segundo uma espécie de essência última ou uma forma conclusiva de relação do sistema com o meio, mas atua como uma "diferença condutora" 86 que serve à sua autodeterminação, deixando aberta, porém, tanto a possibilidade de o subsistema definir sua própria identidade, como também a possibilidade de isso ocorrer segundo diversas opiniões a respeito, numa policontexturalidade de designações de identidade e sem que isso necessariamente restrinja as operações do sistema (LUHMANN, 2000, p. 25-26; 2005b, p. 38).

O código próprio dos meios de comunicação de massa configura a distinção informação/não-informação. Com a informação - que se apresenta como o valor positivo do código -, o sistema pode começar a trabalhar. A liberdade de reconhecer que algo é

\footnotetext{
${ }^{86} \mathrm{Na}$ nota de rodapé $\mathrm{n}^{0} 1$ do capítulo 4, denominado "Universalismo específico do sistema" (LUHMANN, 2000, p. 36-38; 2005b, p. 49-51), Luhmann comenta acerca da expressão "diferença condutora", afirmando que todos os sistemas distinguem as informações que lhes interessam e, com isso, criam um espaço vazio de nãoinformações. Porém, somente o sistema dos meios de comunicação de massa fazem reflexiva tal diferença para poder reconhecer que operações lhe pertencem e quais não lhe pertencem.
} 
informação ou não carrega consigo a possibilidade de se afirmar algo como não-informativo. Considerando, porém, que "mesmo a informação de que algo não é nenhuma informação é também informativa" (LUHMANN, 2005b, p. 39), e que tal circunstância leva a uma regressão infinita, é preciso, na prática, que entrem em cena um conjunto de regras capazes de resolver o "paradoxo da informatividade da não-informação". Tais regras configuram programas "com a ajuda dos quais se pode decidir se algo no sistema deve ser tratado como informativo ou não" (LUHMANN, 2005b, p. 39-40). Ao contrário do código - cuja unidade da diferença não varia -, verifica-se uma pluralidade de programas. Para os meios de comunicação de massa, Luhmann aponta, numa tipologia não fechada, os seguintes campos programáticos: notícias e reportagens; publicidade; e entretenimento. Todas essas áreas utilizam-se do código informação/não-informação, variando dentre elas, contudo, os critérios de seleção das informações (LUHMANN, 2000, p. 38; 2005b, p. 51).

\footnotetext{
Certamente, a mais importante particularidade do código informação/nãoinformação está na relação deste com o tempo. Informações não podem ser repetidas; elas transformam-se em não-informação no momento em que se tornam acontecimento. Uma notícia, quando usada pela segunda vez, mantém certamente seu sentido, mas perde seu valor informativo. Se a informação é utilizada como valor do código, isso significa que as operações do sistema transformam contínua e necessariamente informação em não-informação. (...) O sistema reintroduz constantemente o próprio output, quer dizer, o conhecimento de fatos em si mesmo novamente, e o faz pelo lado negativo do código, como não-informação. Em outras palavras, o sistema envelhece-se a si mesmo (LUHMANN, 2005b, p. 42-43).
}

Por essa dinâmica, ao difundirem as informações, expandindo-as tão amplamente a ponto de criar redundância social a seu respeito, ou seja, a suposição de que já sejam de conhecimento geral, os meios de comunicação de massa produzem a necessidade de substituir a informação redundante por nova informação, mantendo a sociedade sempre desperta, inquieta e preparada para surpresas. Essa intranquilidade e essa irritação específica da sociedade decorrentes da codificação da informação são bem apreendidas e acomodadas pelos meios de comunicação de massa, em sua função de geradores e processadores de irritações entendidas estas como a forma a partir da qual o sistema pode produzir ressonância (mediante operações que lhe são internas) em relação a acontecimentos que ocorrem no meio que lhe é externo (LUHMANN, 2000, p. 31-35; 2005b, p. 44-48). 
E é como efeito dessa "atividade contínua circular de produzir e interpretar as irritações por meio de informações vinculadas a um momento particular" que "surgem as descrições do mundo e da sociedade pelas quais se orienta a sociedade moderna" (LUHMANN, 2005b, p. 159), seja por fora ou por dentro de seu sistema denominado meios de comunicação de massa (LUHMANN, 2000, p. 140). Não se está dizendo que tal sistema de meios de massa é o único habilitado a gerar e processar irritações, já que esta é uma característica geral dos sistemas abertos ao sentido (sistemas sociais e de consciência) (LUHMANN, 2011, p. 106 e ss, p. 228 e ss), nem que ele detenha exclusividade nesse papel de construir valores próprios para a sociedade ou a realidade social de uma maneira geral afinal, toda comunicação serve à construção da realidade, naquilo que contribui ou naquilo que deixa ao esquecimento. Os meios de massa, contudo, possuem um papel fundamental quando se trata da ampla e expansiva difusão e da apropriação anônima e imprevisível do conhecimento (LUHMANN, 2000, p. 147; 2005b, p. 167).

Mencionando observação de Talcott Parsons a respeito do papel dos meios de comunicação de massa nos intercâmbios (interchanges) da sociedade, tendo em vista o aumento do grau de liberdade da comunicação que eles promovem, Luhmann destaca, a respeito, o aumento da irritabilidade que ocorre com eles, bem como a "interpenetração recursiva da comunicação produzida pelos meios de comunicação de massas com a comunicação cotidiana nas interações e nas organizações da sociedade" (LUHMANN, 2005b, p. 161). Assim, ao tempo em que absorvem comunicações, eles estimulam seu trânsito.

A função social dos meios de comunicação de massa não se perfaz ou se reduz à produção de uma "totalidade" de informações sempre atualizadas em cada campo programático, encontrando-se, em verdade, na produção de uma memória social que permite que sejam tomadas como conhecidas e pressupostas algumas suposições sobre a realidade, as quais, justamente por isso, não precisam ser expressamente introduzidas ou justificadas em cada comunicação feita. A atuação dessa memória ou desse pano de fundo aproveita a todas as operações (comunicações) da sociedade enquanto sistema geral abarcador de sistemas sociais parciais, de forma a possibilitar o controle da consistência das comunicações, à luz do mundo conhecido e a ponto de dar margem à discriminação daquelas informações que apareçam como improváveis (LUHMANN, 2000, p. 96). Dessa forma, a partir deste mesmo pano de fundo criado, as pessoas podem emitir juízos, avaliações e opiniões próprias, sem que a exposição de uma pessoa à observação distinta de outra possa ser compreendida como se 
elas vivessem em mundos diferentes. É a realidade comum construída pela memória social que permite que a opinião própria de uma pessoa possa ser avaliada como aceitável, provocativa ou mesmo, no limite, como um caso psiquiátrico (LUHMANN, 2005b, p. 96-97).

De qualquer forma, é importante destacar que os próprios meios de comunicação de massa não produzem uma noção consensual da realidade - e, se tentam fazê-lo, terminam por falhar. Eles corrigem-se a si próprios e contêm e produzem o tempo todo opiniões, comentários e questionamentos diversos. Trabalham, assim, continuamente para o próprio descrédito. Decisivos para sua atuação são, portanto, os temas pautados, não as opiniões. Do ponto de vista daqueles que observam os meios de massa, o próprio conflito passa a ser observado como realidade, sendo certo que, "[q]uanto mais informação tanto maior a incerteza e tanto maior também a tentação de colocar a própria opinião, de identificar-se com ela e sustentar-se nela" (LUHMANN, 2005b, p. 118).

O que se tem é a configuração de uma realidade cuja estabilidade se baseia em objetos - "que são pressupostos na produção da comunicação subsequente" (LUHMANN, 2005b, p. 162) -, constituídos, na sociedade moderna, pelos meios de comunicação de massa, a partir do próprio operar recursivo da comunicação e sem a proibição de seus contrários. Sob condições modernas, existe, assim, a possibilidade de dissenso, ou seja, de se questionar por meio da própria comunicação o consenso formado em torno desses objetos. Testa-se a comunicação por meio da comunicação: a cada comunicação recoloca-se a questão de sua aceitação ou recusa. Os próprios objetos socialmente constituídos podem se converter em temas da comunicação, cabendo aos meios de comunicação de massa, assim, não só torná-los conhecidos, como também de tempos em tempos introduzir variações, de forma a provocar aceitação ou recusa em comunicações posteriores (LUHMANN, 2000, p. 143-144; 2005b, p. 162-163). Nesse choque de comunicações - mas também de uma maneira geral em relação a todas as observações quando elas ocorrem - a memória atua realizando a discriminação entre esquecer e lembrar (LUHMANN, 2005b, p. 164). Como já mencionado alhures neste trabalho, o esquecimento "evita que o sistema bloqueie a si próprio em razão de uma coagulação dos resultados de observações anteriores", liberando-o, assim, em termos de capacidade para processar informações (LUHMANN, 2007, p. 457, tradução nossa). Aquilo que não é esquecido, de sua sorte, configura a realidade construída dentro do sistema a partir de provas de consistência de operações do sistema contra operações do sistema (LUHMANN, 2007, p. 459). Luhmann destaca que todos os sistemas dotados de função possuem uma 
memória específica e que o sistema dos meios de comunicação de massa, assim sendo, tem uma memória que sempre se realiza dentro de si próprio, mas que "presta serviços a algumas funções da sociedade enquanto sistema geral" (LUHMANN, 2000, p. 146, tradução nossa).

O desempenho da memória dos sistemas comunicativos de uma maneira geral, e dos meios de massa, em particular, se dá a conhecer pelos temas da comunicação. Para se ter um tema basta que se organize uma sequência de colaborações e que ela fique aberta a opções de "sim" e "não". Os temas são porções de relevância comunicativa, semelhantes a módulos "locais" que podem ser trocados segundo as necessidades. Em consequência, os temas possibilitam uma memória altamente diferenciada, que tolera uma mudança súbita de tema e que possibilita, com certos cuidados, o retorno ao tema abandonado (LUHMANN, 2000, p. 146, tradução nossa).

Os temas configuram um requisito inevitável da comunicação. São eles que atam os meios de comunicação de massa à sociedade, evitando sua retirada ou "uma guinada para fora da sociedade" (LUHMANN, 2005b, p. 30). Eles servem, portanto, ao acoplamento estrutural dos meios de massa com outros campos ou áreas sociais e, sendo elásticos e diversificados, podem alcançar toda a sociedade. Subsistemas parciais como o direito, a política e a ciência, apresentam, contudo, dificuldades para colocar seus respectivos temas aos meios de massa e de obter uma recepção adequada quanto a eles. É, assim, na imposição dos temas que reside o sucesso dos meios de comunicação de massas - e isso independentemente das posições (positivas ou negativas) tomadas com relação à informação, às proposições de sentido, às valorizações envolvidas. De regra, o interesse no tema surge justamente pelo fato de que ambas as posições são possíveis (LUHMANN, 2000, p. 18-19; 2005b, p. 30-31). Na seletividade dos temas, os meios de comunicação de massa são autônomos: suas operações comunicativas internas dependem, como pressuposto, da própria estrutura do sistema e de sua situação histórica, não havendo nenhum tema que por natureza não possa ser tratado pelos meios de comunicação, ou seja, que possa ser aprioristicamente excluído dos meios de comunicação de massa. Isso não nega o fato de que possa haver determinadas proibições ou restrições jurídicas ou convenções políticas estabelecendo que algo não deva ser (ainda) publicado (LUHMANN, 2000, p. 37; 2005b, p. 50).

$\mathrm{O}$ alto grau de liberdade comunicativa existente dentro do sistema dos meios de comunicação de massa - ou, em termos bem amplos, sua autonomia - faz com que eles possam e tenham que impor limites a si mesmos no tocante aos critérios de seleção. Com relação às notícias, Luhmann (2000, p. 43 e ss; 2005b, p. 57 e ss) elenca vários desses 
critérios ou seletores. Dentre outros, pode-se destacar que, em termos de informação, os conflitos são preferidos, assim como também o são as infrações às normas (sejam transgressões ao direito, à moral ou ao politicamente correto) - sobretudo por se fazerem acompanhadas de valorações morais que levem à estima ou desestima de pessoas. Trata-se de um critério que demonstra o papel dos meios de comunicação de massa na conservação e reprodução da moral, mas que não permite a conclusão de que eles tenham condições de fixar por si próprios princípios éticos ou de manter o nível de moral social sempre na direção do que seja bom - capacidades que, de resto, nenhuma instância da sociedade moderna dispõe por si própria. Embora mostrem, a partir das faltas ou práticas noticiadas, a necessidade de existirem critérios morais, os meios de comunicação de massa apenas reproduzem o código moral bom/mau, ou seja, realizam "uma contínua autoirritação da sociedade, uma reprodução da sensibilidade moral, tanto no plano individual como no comunicativo" (LUHMANN, 2005b, p. 63).

Conforme acentua Luhmann (2000, p. 49-51; 2005b, p. 63-65), para facilitar o reconhecimento das violações às normas, bem como a formação de opiniões por parte dos leitores ou telespectadores, os meios de comunicação focam em ações e em tornar acessíveis a atribuição delas a determinados agentes, sem aprofundar suficientemente o contexto complexo que leva atores a fazer algo a que não estavam obrigados. Considerando que nem as ações nem os agentes podem ser tomados como fatos empíricos - já que os limites e a unidade de uma ação e de um agente não podem ser vistos nem ouvidos -, trata-se de um modo de atuação baseado em "compressões tipificantes" e em constructos institucionais ou culturais, que suscita, "[e]ntre os meios de comunicação e aquilo que se passa como realidade na experiência cotidiana", "um contínuo copiar de padrões, um copiando o outro, e, com isso, formas de agir incomuns são polidas e reconstruídas" (LUHMANN, 2005b, p. 64). Na mesma toada, há um interesse focal pelas pessoas (de uma forma que não depende de acesso aos indivíduos em seus processos bioquímicos, neurofisiológicos ou psíquicos), sobretudo "em tempos que vivem seu futuro como algo dependente de ações e decisões". Pessoas conhecidas (por conta dos meios de massa) servem como "símbolos palpáveis" perante um futuro que não se conhece, sobre os quais recai "a esperança de poder eventualmente influenciar seu agir" (LUHMANN, 2005b, p. 64-65). 
A informação a ser noticiada, ademais, tem de ser nova, atual e gerar surpresa. A atualidade faz com que as notícias se concentrem em casos recém ocorridos, particulares ou específicos (acontecimentos, acidentes, distúrbios etc.). Como o sistema, "apesar de suas grandes capacidades de armazenamento", está "orientado a esquecer e lembrar rapidamente" (LUHMANN, 2000, p. 24, tradução nossa, grifo do original), "a repetição de notícias não é algo facilmente aceito" (LUHMANN, 2000, p. 44, tradução nossa) - o que pode vir a ocorrer, contudo, em determinadas situações, como secundariamente para situar desdobramentos da notícia ou receptores eventualmente não devidamente inteirados. De forma mais geral, tem-se que a recursividade faz com que as informações subsequentes demandem referência a acontecimentos anteriormente ocorridos e noticiados, seja porque eles adquiriram uma significação típica, seja porque eles perfazem um contexto narrativo cuja continuidade ainda prossegue. Por vezes, os acontecimentos noticiados ensejam a notícia de ocorrências semelhantes e, assim, a divulgação de séries de acontecimentos.

\footnotetext{
É evidente que os acontecimentos só se dispõem a procurar recursões ${ }^{87}$ e a construir séries sob condições especiais. Para tal revalorização podem contribuir notícias adicionais que se refiram à extensão dos danos causados, à catástrofe por pouco evitada, ao atingimento daqueles que não estavam envolvidos (possivelmente, portanto, de todo mundo) e à suspeita de encobrimento por parte dos responsáveis. Essas condições podem não ser constantes, mas variar com o suposto interesse do público. Como sempre, os meios de comunicação dão uma coloração especial àquilo que noticiam e à forma como noticiam; assim, decidem sobre o que deve ser esquecido, o que pode ser significativo apenas no momento e o que deve permanecer na lembrança (LUHMANN, 2005b, p. 66-67).
}

A própria manifestação de opiniões - parte significativa do material da imprensa, da televisão e do rádio -, por outro lado, pode ser divulgada como notícia, numa atitude em que os meios de comunicação de massa espelham-se em si mesmos e tratam isso como acontecimento. Os comentários emitidos podem gerar críticas e essas, por sua vez, podem tornar a gerar comentários, numa dinâmica que possibilita que os meios de comunicação de massa ajustem-se às mudanças na opinião pública que eles mesmos tenham produzido. Os acontecimentos reais e os acontecimentos de opinião (ou o desenvolvimento de opiniões a respeito de acontecimentos reais) misturam-se e entrecruzam-se continuamente, formando

\footnotetext{
${ }^{87}$ Neste ponto, a tradução em espanhol fala em "recursividade" (LUHMANN, 2000, p. 52).
} 
para o público uma massa fluida de comunicação na qual se distinguem os temas, mas não a origem das informações (LUHMANN, 2000, p. 52-53; 2005b, p. 67-68).

Diferentemente das notícias, as reportagens não dependem dos acontecimentos que diariamente se sucedem. Elas procuram retratar ou informar sobre o contexto onde ocorrem eventuais novidades, complementando o caráter temporário ou passageiro das notícias. Fazem-se reportagens sobre países longínquos, sobre certas doenças, sobre os desenvolvimentos da ciência etc., as quais tem seu caráter de novidade assegurado a partir do suposto nível de conhecimento do público a que se dirigem (LUHMANN, 2005b, p. 69-70).

Luhmann destaca que as diferenças entre as notícias e as reportagens têm se tornado fluidas, em virtude da capacidade de armazenamento eletrônico cada vez maior das notícias publicadas, possibilitando que elas permaneçam acessíveis para renovadas recuperações. Assim, e a depender das necessidades, o que foi notícia pode ser resgatado como reportagem. "O sistema produz então continuamente informações com base em informações à medida que produz contextos de reportagens nos quais novidades há muito tempo abandonadas e esquecidas ganham novamente valor informativo" (LUHMANN, 2005b, p. 70) ${ }^{88}$. A respeito disso, Luhmann chama a atenção para o papel que os sociólogos têm na identificação das finalidades que estão a ensejar essa segunda valorização da informação e em que situações ela está sendo utilizada.

O mais evidente é considerar aqui, em primeiro lugar, as intenções de desacreditar pessoas - destruir pessoas publicando mais uma vez sua história, mas também, por exemplo, para demonstrar a inércia das instituições políticas, que jamais reagiram a fatos há muito conhecidos. Se essa suposição se confirma, teríamos aí uma oportunidade para questionar os motivos para a reatualização de verdades verdades, que pelo seu caráter de serem antigas, mal podem ainda ser comprovadas (LUHMANN, 2005b, p. 70) $)^{89}$.

\footnotetext{
${ }^{88}$ Os casos Lebach 1 e 2 e os Recursos Especiais $n^{\circ} 1334097 / \mathrm{RJ}$ e $\mathrm{n}^{\circ}$ 1335153/RJ possuem substratos factuais bem elucidativos do que Luhmann está a referir.

${ }^{89}$ Deve-se destacar que as observações de Luhmann feitas a partir da constatação da fluidez entre notícias e reportagens datam de meados da década de 1990. Segundo ele, contudo, a referida fluidez já ocorreria "há bons dez anos" (LUHMANN, 2005b, p. 70), sendo, portanto, ainda mais antiga. Pelas datas, ele certamente tinha em mente, aqui, já avanços no armazenamento de dados, mas não ferramentas do alcance dos motores de busca como o Google Search. O avançar da tecnologia, contudo, longe de infirmar suas observações sobre este ponto, terminou por deixá-las ainda mais atuais. O direito ao esquecimento, como visto, possibilita justamente o questionamento quanto ao uso posterior que se faz com informações verdadeiras, mas já antigas e esquecidas.
} 
Quanto à verdade (ou a suposição da verdade), Luhmann aponta que ela é indispensável para as notícias e reportagens, mas que os meios de comunicação não se baseiam pelo código verdade/não-verdade - que é típico do sistema da ciência - e sim, como visto, pelo código informação/não-informação. Logo, de maneira distinta da ciência, não há uma reflexão exaustiva quanto à informação, "a ponto de poder ser constatado - de uma forma verdadeira - que antes que seja afirmada a verdade a inverdade já [tenha sido] excluída" (LUHMANN, 2005b, p. 71). Os erros, assim, podem vir a ocorrer, mas, uma vez constatados, devem ser explicados, garantindo-se aos atingidos instrumentos voltados à correção. De qualquer forma, tais erros devem permanecer como fatos isolados, pois, do contrário, "desmoronaria aquilo que torna específico esse espaço de notícias e reportagens na programação" (LUHMANN, 2005b, p. 55).

A construção contínua da realidade levada a efeito pelos meios de comunicação de massa termina, ainda, por desafiar o entendimento reinante sobre a liberdade - ou seja, a ideia de liberdade enquanto ausência de coações. Segundo Luhmann (2000, p. 125-126; 2005b, p. 143-144), a "inocência" social dos meios de massa se baseia no fato de que eles não coagem a nada, não forçam ninguém a nada. A variedade de possibilidades e de escolhas para os sistemas psíquicos e sociais, contudo, pressupõe uma memória, isto é, uma "rede recursivamente estabilizada de redundâncias" (LUHMANN, 2005b, p. 144), para a qual os meios de comunicação de massa trabalham. Sua atuação cria realidades de efeitos muito profundos sobre o que a sociedade observa como liberdade (LUHMANN, 2000, p. 126), ou seja, realidades que instituem uma "ordem em relação àquilo que em sociedade pode ser observado como liberdade e, com isso, principalmente, em relação à questão de como são distribuídas as chances do agir que é atribuível a cada um em sociedade" (LUHMANN, 2005b, p. 144).

Embora Luhmann $(2000 ; 2005 b)$ tenha focado no que comumente se entende por meios de comunicação de massa (jornais, televisão e rádio), deixando de fora de sua investigação manifestações como as que ocorrem na internet, Nafarrate (2000, p. XX) aponta que certas categorias das mídias de massa tradicionais poderiam ter aplicação nesta nova realidade da internet. Isso parece, de fato, fazer sentido. Não se trata de colocar palavras na boca de Luhmann, mas de evidenciar que suas observações quanto aos meios de comunicação 
de massa alcançam muito do que hoje perfaz a realidade da internet, das mídias digitais ${ }^{90}$. Embora a ideia de mídias digitais (ou de expressões como "nova mídia", "novas mídias", "novas tecnologias", "meios eletrônicos") tenha um uso, de uma maneira geral, voltado para marcar diferenças com relação aos (conhecidos) meios de comunicação de massa (MARTINO, 2015, p. 10), certo é que tais mídias digitais se prestam a formas variadas de comunicação que terminam por abarcar elementos e funções típicas dos meios de massa tradicionais - os quais, aliás, já cuidaram de migrar eles mesmos para plataformas virtuais, num movimento de "convergência empresarial crescente entre corporações de telecomunicação, de computadores, da internet e da mídia” (CASTELLS, 2015, p. 103) (11. $^{91}$.

O fato de hoje em dia as comunicações ocorrerem amplamente através de meios digitais e da internet, num ambiente de rede que certamente permite e aumenta o grau de autonomia e de interação ${ }^{92}$ entre os participantes, não significa que toda comunicação virtual tenha se tornado interativa - a ponto de envolver sempre uma interpessoalidade ou sujeitos determinados ou determináveis -, ou tenha se tornado presencial (no sentido de ocorrer num mesmo tempo, ainda que mediada pela técnica, ou seja, presencialmente mas à distância como ocorre com ligações telefônicas, chats etc.), a ponto de estabelecer sempre uma bidirecionalidade, ou seja, uma conversação retroalimentada, que possibilita em tempo real indagações, correções e certificações quanto ao que se diz. Também não se pode dizer que a liberdade de participação e de produção de conteúdo aberta a todos tenha acabado com

\footnotetext{
${ }^{90}$ Circunstância que coloca o desafio de contrastar o pensamento de Luhmann com as novas mídias, as novas tecnologias e a nova "realidade social". Considerando que o presente trabalho tem como objeto o direito ao esquecimento, o desafio em questão não terá como ser aqui devidamente enfrentado. O pensamento de Luhmann é resgatado, neste ponto, como forma de contextualizar o funcionamento dos meios de comunicação de massa, tendo em vista a compreensão de como eles podem vir a avançar negativamente sobre a sociedade e os indivíduos e, ainda, tendo em vista a preocupação de enquadrar veículos de comunicação distintos (como a televisão e os motores de busca da internet) dentro de um mesmo sistema funcional da sociedade, buscando-se com isso assegurar a incidência do direito ao esquecimento sobre eles, sem distinções de tratamento como as feitas pelo STJ (que pretendeu limitar o direito ao esquecimento apenas à mídia televisiva, em virtude de questões tecnológicas e de questões envolvendo competências territoriais de Estados-nação).

91 " [A] internet está sendo cada vez mais usada para acessar a mídia de massa (televisão, rádio, jornais) bem como qualquer forma de produto cultural ou informacional digitalizado (filmes, música, revistas, livros, artigos de jornais, bancos de dados)" (CASTELLS, 2015, p. 112).

92 De acordo com Martino (2015, p. 11), a interatividade é um dos conceitos-chave para a compreensão das mídias digitais, podendo ser entendida como a "[i]nterferência e interação entre usuários, ou usuários, programas e conteúdos, em diferentes níveis e formas, nos sistemas de comunicação digital em rede".
} 
organizações responsáveis pela concretização e operacionalização do sistema dos meios de comunicação de massa e do código próprio que distingue informação de não-informação ${ }^{93}$.

A respeito de tal contexto, Castells (2015, p. 101 e ss) fala da existência de três formas de comunicação: a comunicação interpessoal, a comunicação de massa tradicional e a autocomunicação de massa. A primeira seria interativa, imediata, presencial, com mensagens dirigidas de um para outro com laços de retroalimentação. Na segunda, marcada por ser eminentemente unidirecional e sem contato interativo direto, a mensagem seria enviada de um para muitos - caso dos livros, jornais, filmes, rádio, televisão. A terceira seria historicamente mais nova, interativa e decorrente da difusão da internet.

Chamo essa forma de comunicação historicamente nova de autocomunicação de massa. É comunicação de massa porque tem o potencial de atingir um público global, como é o caso de um vídeo divulgado no YouTube, um blog com links RSS para várias fontes na internet, ou uma mensagem para uma lista gigantesca de emails. Ao mesmo tempo, é autocomunicação porque a produção da mensagem é autogerada, a definição do(s) receptor(es) potencial(ais) é autodirecionada e a recuperação das mensagens específicas, do conteúdo da World Wide Web (WWW, a rede de alcance mundial) e de redes eletrônicas de comunicação é autosselecionada. As três formas de comunicação (interpessoal, comunicação de massa e autocomunicação de massa) coexistem, interagem e se complementam em vez de se substituírem $^{94}$. O que é historicamente novo, com consequências consideráveis para a organização social e a mudança cultural, é a articulação de todas as formas de comunicação em um hipertexto digital composto e interativo que inclui, mistura e recombina em sua diversidade toda a variedade de expressões culturais transmitidas pela interação humana (CASTELLS, 2015, p. 102, grifos do original).

\footnotetext{
${ }^{93}$ Castells destaca que a crescente interação entre redes horizontais e verticais de comunicação "não significa que a mídia tradicional esteja dominando as formas novas e autônomas de geração e distribuição de conteúdo". Há, na verdade, um processo de complementaridade que cria uma nova realidade midiática, cujos contornos e efeitos serão decididos, em última instância, a partir de lutas de poder político e empresarial (CASTELLS, 2015, p. 118). De qualquer forma, tem-se que "as empresas que formam o núcleo das redes internacionais de mídia estão adotando políticas de concentração de propriedade, parcerias entre companhias, diversificação de plataformas, customização de audiências e economias de sinergia com diferentes níveis de sucesso" (CASTELLS, 2015, p. 133, grifo do original).

94 Além dos vários tipos de comunicação que viabiliza, a internet contribui sobremaneira para tornar anônima a redundância social (com grande descolamento da comunicação de suas fontes originais), já que permite a difusão veloz, ilimitada e global da comunicação e, ainda, de forma criativa e participativa (a partir do corte, adição, recombinação, enfim, edição de informações disponíveis na rede).
} 
Novos instrumentos (ou veículos) dos meios de comunicação de massa, típicos da realidade digital, como os motores de busca, parecem estabelecer uma espécie de acoplamento estrutural com seu meio externo, ou seja, com as pessoas, de forma a possibilitar que elas - à semelhança do que acontece com os temas na comunicação de massa tradicional gerem influxos ao sistema a partir da definição de critérios para localização das informações ou, nos termos gerais colocados por Castells, a partir da autosseleção do conteúdo da internet a ser recuperado. Tal circunstância não afasta o fato de que entre os motores de busca e os usuários há a interposição de uma técnica ou de uma tecnologia que rompe o contato imediato e direto. Embora a comunicação seja tematizada e mostrada por "provocação" ou iniciativa do usuário, não se estabelece uma conversação entre presentes, nem uma determinação do conteúdo dos resultados de busca por parte dos usuários-receptores. Como afirma o próprio Google - gerenciador do motor de busca mais conhecido, o Google Search - "[a] jornada de uma consulta começa antes mesmo que você digite sua pesquisa, com o rastreamento e a indexação de trilhões de documentos pela Web"95 - os quais, aliás, incluem de tudo, desde comunicações produzidas por grandes organizações da comunicação de massa (como as que formam a imprensa, os jornais), até postagens individualmente produzidas (em blogs, páginas e perfis de mídias sociais etc.), passando e transpassando, assim, também, por dados pessoais cujo uso ou reuso está, como já abordado neste trabalho, sujeito a questionamentos.

95 GOOGLE. Por dentro da pesquisa: como a pesquisa funciona. Disponível em: $<$ https://www.google.com/intl/pt-br/insidesearch/howsearchworks/>. Acesso em: 01 ${ }^{\circ}$ mar. 2016. Veja-se, conforme destacado no caso Equustek, que o Google antecipa mesmo sugestões e quesitos de busca, à medida que se começa a digitar. Pertinente, portanto, é a observação de Luhmann de que, com a técnica e sob o contexto dos meios de comunicação de massa, há uma modificação em ambos os lados (emissor e receptor) da comunicação, de forma que já não se seleciona na comunicação em si, mas para a comunicação. Isso não parece ter mudado com o fato de que os usuários-receptores hoje em dia podem gerar influxos temáticos sobre os motores de busca. Diz Luhmann: "Em muitos casos - com exceção do telefone - a técnica obriga à unilateralidade da comunicação. Em parte, isso é consequência de os aparelhos estarem instalados como intermediários e, em parte, é uma exigência da comunicação de massas com a qual a impressão ou tipografia já havia se resignado. Este fato transforma o sucesso da seleção e, para ser preciso, o transforma de ambos os lados do mecanismo. Já não se seleciona na comunicação, mas para a comunicação. $\mathrm{O}$ emissor elege os temas, as formas, as encenações e, sobretudo, os tempos de transmissão e duração à luz do que lhe parece conveniente. $\mathrm{O}$ receptor seleciona a si mesmo, à luz do que quer ver e ouvir. A comunicação, então, realiza-se como um hiperciclo de recíproca seleção, mas na medida em que simplesmente acontece não pode se corrigir a si mesma" LUHMANN, 2007, p. 239, tradução nossa, grifos do original). Hoje em dia, muito do que parecia deixado à pura conveniência do emissor parece estar cada vez mais "aberto" (embora não determinado) a influxos provenientes do meio (das pessoas que formam a "audiência") - e isso é válido não só para as novas mídias digitais, como também, por exemplo, para a televisão. A televisão fragmentou-se em canais especializados para determinados públicos, juntamente com o desenvolvimento de tecnologias (capazes de programar a gravação de transmissões, de pular anúncios, de programar de forma computadorizada o que vai ser assistido etc.) que abriram margem para a possibilidade de customização da própria recepção (CASTELLS, 2015, p. 107). Há, de uma maneira geral, uma combinação de produção de massa e de distribuição customizada de conteúdo (CASTELLS, 2015, p. 170). 
Doutro lado, os motores de busca funcionam como meios eletrônicos que contribuem para a redundância global da comunicação social, ampliando sobremaneira no tempo e no espaço os receptores de uma comunicação - os usuários-receptores da comunicação podem ser quaisquer pessoas do globo. Considerando a quantidade de informações disponíveis na internet, a atuação dos motores de busca na sua localização e na sua difusão ganha, assim, contornos sensíveis, a ponto de se dizer, comumente, que "se não está no Google, não existe”. Como enfatizado por Mayer-Schönberger (2009, p. 81), enquanto a informação digital que está conectada à rede global é valiosa, aquela que não está não é diferente da informação que foi simplesmente esquecida.

Embora figurem como uma espécie de apoio externo para registro de uma memória social, os motores de busca não funcionam como um mero repositório de comunicações passadas. Não são um simples arquivo passivo de informações - ou de nãoinformações, ou seja, informações que não mais têm ou teriam interesse. Uma pesquisa por um determinado critério de busca não apresenta sempre um mesmo resultado estático. Comunicações novas e velhas misturam-se numa atualização contínua, que varia de acordo com inúmeros fatores (incluindo perfis e históricos dos usuários), os quais, de regra, estão condensados em algoritmos - que são programas que estabelecem critérios para a construção da resposta buscada com a pesquisa. Como o próprio Google afirma, “[v]ocê quer a resposta, e não trilhões de páginas da web"96. E é a partir dessa dinâmica que cada resposta, configurando uma construção ${ }^{97}$ feita a partir das trilhões de páginas disponíveis na internet,

96 GOOGLE. Por dentro da pesquisa: como a pesquisa funciona. Disponível em: $<$ https://www.google.com/intl/pt-br/insidesearch/howsearchworks/>. Acesso em: 01 mar. 2016

97 Para além da atuação dos algoritmos, o Google estabelece algumas políticas para cumprir seu desiderato de
"organizar a informação disponível no mundo". Dentre elas, destacam-se a identificação e exclusão, em
controles automáticos ou manuais, de páginas de spam, e o bloqueio de resultados de pesquisa que levam a
conteúdos de pornografia infantil - aqui, em virtude de "uma exigência legal" e de "uma questão de
moralidade". Sobre "conteúdo chocante", o Google informa que: "[q]ueremos ter a certeza de que as
informações estarão disponíveis quando você procurar por elas, mas também queremos ter o cuidado para não
mostrar conteúdo potencialmente constrangedor quando não solicitado. Dessa forma, podemos não disparar
certos recursos de pesquisa para consultas cujos resultados possam ser ofensivos em diversas categorias pouco
definidas". Já no tocante à "Prevenção ao roubo de identidade", o Google afirma que: "[m]ediante pedido,
removemos informações pessoais dos resultados de pesquisa quando acreditamos que elas possam tornar você
suscetível a danos específicos, como roubo de identidade ou fraudes financeiras. Isto inclui números de
identificação confidenciais do governo como o CPF no Brasil, números de contas bancárias, números de cartões
de crédito e imagens de assinaturas. Normalmente, não processamos remoções de números de identificação
nacionais de websites oficiais do governo, pois nestes casos consideramos que as informações são de domínio
público. Podemos recusar solicitações se acreditarmos que alguém está tentando abusar destas políticas para
remover outras informações de nossos resultados". Por sua vez, ao cuidar de remoções em decorrência de razões
jurídicas, o Google esclarece o seguinte: "[à]s vezes, removemos conteúdo ou recursos de nossos resultados de
pesquisa por razões jurídicas. Por exemplo, removeremos conteúdo se recebermos uma notificação que se 
pode se apresentar como uma surpresa, uma novidade para aquele que a busca. Há, assim, um tratamento das informações e das comunicações que as coloca - independentemente do momento em que originalmente produzidas ou veiculadas - numa mesma temporalidade, num mesmo presente e num conjunto contextual e comunicacional único que não se confunde com os contextos originais específicos de cada comunicação, formando uma realidade nova bastante palpável para aquele que com ela se defronta. Os pedaços de informações são descontextualizados e recontextualizados ao serem apresentados como resultados de busca (MAYER-SCHÖNBERGER, 2009, p. 90), configurando o que, aos olhos de quem busca a informação, parece ser a realidade total e atual do tema procurado - realidade esta marcada, sobretudo, pelas comunicações mais importantes, ou seja, aquelas que aparecem em links nas primeiras colocações do ranking de resultados ${ }^{98}$. Nessa toada, as palavras de Luhmann acerca da comunicação por computadores soam bastante atuais:

Ao permitir que a introdução-de-dados no computador se separe tanto da informação-solicitada, deixa de existir alguma identidade entre os dois processos. Relativamente à comunicação isto significa que se abandona a unidade de dar-aconhecer e entender. Quem ingressa algum dado não sabe (e se soubesse não teria necessidade do computador) o que será extraído pelo outro lado. Nele, entretanto, os

encaixa no Digital Millenium Copyright Act - DMCA (em português, Lei dos Direitos Autorais do Milênio Digital) nos Estados Unidos. Também removemos conteúdo de versões locais do Google em concordância com as leis locais quando somos notificados de que há um problema. Por exemplo, removeremos conteúdo que celebra o partido nazista de forma ilegal no Google da Alemanha ou que ofende a religião islâmica da mesma forma no Google da Índia. Sempre que removemos conteúdo da Pesquisa por razões jurídicas, mostramos uma notificação de que os resultados foram removidos e reportamos estas remoções para o chillingeffects.org, um projeto administrado pelo Berkman Center for Internet and Society (em português, Centro Berkman para Internet e Sociedade), que acompanha restrições à liberdade de expressão na Internet. Também divulgamos alguns detalhes sobre remoções jurídicas por meio de nosso Relatório de Transparência". A respeito, conferir: GOOGLE. Por dentro da pesquisa: como a pesquisa funciona. Disponível em: $<$ https://www.google.com/intl/pt-br/insidesearch/howsearchworks/>. Acesso em: 01 mar. 2016.

${ }^{98}$ A respeito, a observação de Castells é digna de nota: "À medida que mais e mais produtos de mídia são distribuídos e consumidos on-line, e integrados às redes sociais e a outros conteúdos gerados pelos usuários, o comportamento do usuário individual ganha mais relevância para estimular a publicidade. Atualmente, os mecanismos de busca on-line são configurados de tal forma a incluir a participação tácita - embora não necessariamente consciente - do usuário final. Observadores apontam para a crescente importância do Googlearchy (Googlearquia), referindo-se ao posicionamento dos itens de busca nos resultados da busca (Hindman et al., 2003). A Google, a Yahoo! e outros sites usam uma combinação de relevância da palavrachave, a popularidade dos termos de busca, as conexões com outros sites e o comportamento dos usuários finais para determinar a ordem dos resultados de busca. À medida que um número cada vez maior de usuários segue links específicos, mais aumentam essas fontes na Googlearquia. Usuários de mecanismos de busca estão assim simultaneamente consumindo informação e ajudando a determinar a acessibilidade e a predominância daquela fonte de informação para outros usuários na esfera da internet. Isso provoca um efeito dominó. É mais provável que os usuários cliquem em um link entre as primeiras páginas de resultados. Com isso, a relevância gera relevância. Buscas sobre temas africanos, por exemplo, não utilizam muito fontes africanas, já que elas não estão entre o primeiro grupo de resultados. Só usuários sofisticados podem alcançar fontes que não foram classificadas nas primeiras posições segundo os critérios programados pela Google" (CASTELLS, 2015, p. 150-151). 
dados se "processam". (...) De igual maneira se elimina a possibilidade de reconhecer o propósito de dar-a-conhecer uma comunicação e alimentar a partir daí a desconfiança ou tirar conclusões que poderiam levar a sua aceitação ou recusa. $\mathrm{O}$ que ocorre é uma absorção de insegurança que se controla a si mesma em medida limitada. (...) Assim, o desacoplamento social do substrato medial da comunicação vai ao extremo. Em nossa concepção isso significa que está por nascer um novo medium cujas formas agora dependem de programas de computador. Embora esses programas não sejam os que decidem como o meio condensa a comunicação mesma em formas - porque para isso necessita-se do sucesso do ingresso de dados e do pedido de informações -, eles são, contudo, formas - como antes já foram as regras gramaticais da linguagem - que delimitam as possibilidades do acoplamento firme e assim podem ampliá-lo até o imprevisível (LUHMANN, 2007, p. 240, tradução nossa, grifo do original).

Essa forma de atuar dos motores de busca aproveita-se daquilo que MayerSchönberger (2009) identificou de uma maneira geral e que Luhmann reportou de uma forma mais específica quando tratou da fluidez cada vez maior entre notícias e reportagens: a facilidade de armazenamento e recuperação de dados, que permite que informações passadas ("não-informações") ganhem novo valor informativo. Isso acontece em resultados de pesquisas feitas em motores de busca, mas também quando canais de televisão resolvem fazer reportagens em cima de material que compôs notícias passadas. São situações que ensejam justamente discussão quanto aos propósitos e as formas com que tais informações verdadeiras são resgatadas e reatualizadas e que dão azo à emergência de discursos voltados a estabelecer limites e garantias para as pessoas afetadas - como o direito ao esquecimento.

\subsection{O direito ao esquecimento como limite à expansão dos meios de comunicação de massa}

De acordo o pensamento sistêmico de Luhmann, a sociedade consubstancia-se numa "conexão autorreferencialmente fechada de comunicações", em que figuram como unidades elementares, portanto, as comunicações e não os seres humanos, indivíduos ou grupos humanos - os quais pertencem ao ambiente externo da sociedade e de seus subsistemas (NEVES, 2008, p. 3-4). É a própria comunicação, assim, "no curso de sua própria sequência", que "produz as identidades, as referências, os valores próprios, os objetos, 
independentemente do que experimentem os seres humanos particulares ao se confrontarem com tais constructos" (LUHMANN, 2007, p. 15, tradução nossa). Conforme já acima enfatizado, não obstante pressuponha o concurso de inúmeros sistema psíquicos ou de consciência para se concretizar, a comunicação é a operação genuinamente social porque (e justamente por isso) não pode ser atribuída a nenhuma consciência isolada para se perfazer. Por outra banda, "ela é social, porque de modo algum pode ser produzida uma consciência comum coletiva, isto é, não se pode chegar ao consenso, no sentido de um acordo total; e, no entanto, a comunicação funciona" (LUHMANN, 2011, p. 91) $)^{99}$.

Nesse sentido, e considerando "[n]ão [ser] possível imaginar que a consciência tivesse surgido no processo de evolução sem ter havido comunicação; assim como também seria impossível que pudesse haver comunicação de conteúdos significativos sem ter havido consciência” (LUHMANN, 2011, p. 133), deve-se reconhecer que uma não pode existir sem a outra, estando ambas - enquanto sistemas autônomos distintos - acopladas estruturalmente entre si, por meio da linguagem (LUHMANN, 2011, p. 134). Isso não significa que a consciência seja sujeito ou substrato da comunicação (como se a comunicação pudesse ser entendida como uma transferência de conteúdos de um sistema psíquico a outro, de um ser humano a outro - o que não é) (LUHMANN, 2007, p. 76; 2011, p. $133^{100}$ ). Só a comunicação pode comunicar, de forma que comunicação enseja comunicação. "Não existe comunicação de consciência a consciência - que não seja socialmente mediada, assim como não existe comunicação entre indivíduo e sociedade" (LUHMANN, 2007, p. 76, tradução nossa). Contudo, e até pelo modo silencioso como o acoplamento entre consciência e comunicação funciona, isso não impede em absoluto que aqueles que tomam parte no sucesso comunicativo ou a quem as palavras são dirigidas possam ser identificados. Nesse sentido, referências externas que emitem uma mensagem ou que dão-a-conhecer uma informação podem ser identificadas enquanto pessoas (LUHMANN, 2007, p. 77). Assim, "[c]omo forma de dois lados, a pessoa constitui um acoplamento estrutural entre homem e sociedade" (NEVES, 2009, p. 255). As pessoas são, assim, artefatos, constructos dentro da comunicação, que permitem a atribuição de ações e que figuram como "pontos reais de contato com os seres humanos individuais "lá de fora"” (TEUBNER, 2012, p. 142).

\footnotetext{
${ }^{99}$ Para maiores detalhes sobre este ponto, conferir Luhmann (2007, p. 11 e ss).

${ }^{100}$ Vide ainda Luhmann (2011, p. 293 e ss)
} 
É por meio da máscara da "pessoa" que os sistemas sociais fazem contato com seres humanos de carne e osso; enquanto aqueles não podem se comunicar com esses, podem massivamente irritar esses últimos e, a seu turno, ser irritados por eles. Em círculos de perturbação estreitos, a comunicação irrita a consciência com suas "indagações" seletivas, condicionadas por premissas envolvendo atores racionais, e é irritada pelas "respostas", de sua sorte também altamente selecionadas (TEUBNER, 2012, p. 142, tradução nossa).

O surgimento de uma ordem social funcionalmente diferenciada na Modernidade, ou seja, de uma diferenciação da sociedade em sistemas comunicativos (como a política, o direito, a arte, a economia, os meios de comunicação de massa etc.), dotados cada qual de uma função e de uma racionalidade próprias, remonta, dentre outros aspectos, ao incremento historicamente identificado da complexidade social, que colocou em xeque formações sociais pré-modernas hierarquicamente estabelecidas - as quais fundiam num amálgama vários aspectos sociais (política, moral, religião etc.). O desfazimento desse amálgama deu ensejo à emergência de uma sociedade multicêntrica ou policontextural, ou seja, de uma sociedade que não dispõe de um centro ou de um lugar privilegiado do qual emane uma racionalidade e um critério último para observação e descrição da sociedade. Tendo a diferença entre sistema e ambiente se espraiado para diversos âmbitos de comunicação, isso significa a possibilidade de que cada esfera autônoma de comunicação (cada sistema) venha a afirmar pretensões de ser o "centro do mundo", a partir de sua própria diferença, racionalidade parcial e forma específica de "ver o mundo" (ou de autodescrever a sociedade) (NEVES, 2009, p. 22-24). Não havendo um sistema ou mecanismo capaz de unificar a compreensão de todos os distintos sistemas (cada qual dotado de um código próprio orientador da sua comunicação), "[é] claro que isso leva a tensões, pois dessa maneira as diversas racionalidades confrontam-se com outras racionalidades, cada uma delas com pretensão de universalidade” (NEVES, 2009, p. 24).

Mas a sociedade moderna nasce [também] como sociedade mundial, apresentandose como uma formação social que se desvincula das organizações políticas territoriais, embora estas, na forma de Estados, constituam uma das dimensões fundamentais à sua reprodução. Ela implica, em princípio, que o horizonte das comunicações ultrapassa as fronteiras territoriais do Estado. Formulando com maior abrangência, tornam-se cada vez mais regulares e intensas a confluência de comunicações e a estabilização de expectativas além de identidades nacionais ou culturais e fronteiras político-jurídicas (NEVES, 2009, p. 26). 
Tendo em vista que o presente trabalho diz respeito ao discurso cristalizado num direito fundamental ao esquecimento (assim densificado sobretudo a partir de transformações técnicas e sociais, da impregnação de novos sentidos à ideia de privacidade e de novas pretensões jurídicas daí decorrentes), cabe fazer algumas considerações acerca do papel, então, que os direitos fundamentais (e direitos humanos) exercem nesse contexto global de ordens diferenciadas de comunicação.

Neves (2009, p. 249 e ss) destaca que a ideia de direitos do homem ou humanos teria surgido no contexto das revoluções liberais, diferenciando-se do conceito de cidadania. Enquanto os direitos humanos diziam respeito "a direitos de toda e qualquer pessoa humana", a cidadania referia-se "aos direitos dos membros de uma determinada coletividade política e, mais precisamente, de um Estado" - sendo de apontar, de toda sorte, que a própria ideia de direitos humanos carregava consigo também a noção de um direito a ter direitos, ou seja, de um direito de toda pessoa à cidadania (NEVES, 2009, p. 249). Já sob influência da experiência tardia alemã com o constitucionalismo, ganhou curso a ideia de direitos fundamentais como aqueles positivados e garantidos em constituições estatais, com um conteúdo que incluía, porém, os direitos particulares tradicionais de cidadania e os direitos humanos. Posteriormente, passou-se a falar dos direitos fundamentais enquanto aqueles garantidos pelos Estados e dos direitos humanos como aqueles protegidos internacionalmente, inclusive em face dos Estados. O conteúdo de ambos, todavia, estava entrecruzado entre direitos civis, políticos, sociais, coletivos e referentes às ações afirmativas (NEVES, p. 250).

Luhmann (2010, p. 98 e ss) entende os direitos fundamentais como uma instituição da sociedade voltada funcionalmente para reagir ao perigo da desdiferenciação comunicativa da ordem social, procurando garantir ou consolidar a abertura da comunicação à diferenciação, ou seja, as possibilidades de comunicação, a sua disponibilidade. Ao perigo da desdiferenciação, os direitos fundamentais atuariam, portanto, como instituições corretivas e bloqueadoras.

Os direitos fundamentais relacionam-se com este momento do desenvolvimento civilizatório da sociedade - por isso são algo inteiramente distinto dos "direitos humanos" eternos - e confirmam isso na medida em que intentam rechaçar as tendências involutivas nele contidas. Impedem que todas as comunicações se dirijam aos fins particulares da burocracia estatal, fazendo assim possível que ditos fins se racionalizem em direção a uma prestação funcional específica - o que pressupõe 
sempre outras prestações, outros sistemas de consecução de interesses, outras fontes de poder e de prestigio social na ordem da sociedade.

O perigo de desdiferenciação (o perigo de politizar a maneira de ser da comunicação) encontra-se implicado na emancipação da sociedade e no postulado de autonomia do sistema político ${ }^{101}$ (LUHMANN, 2010, p. 99, tradução nossa, grifo do original).

Não passa despercebido a Neves (2009, p. 251) que a dicotomia luhmanniana entre direitos fundamentais (positivados constitucionalmente), enquanto reação ao perigo de desdiferenciação, e direitos humanos, eternos, colocava estes últimos numa condição desprezada. É algo que, segundo o autor, o próprio Luhmann posteriormente veio a rever, passando a relacioná-los ao problema da exclusão, "orientando-se, portanto, para a inclusão do homem como pessoa nos sistemas funcionais da sociedade, especialmente o direito" (NEVES, 2009, p. 251). De qualquer forma, Neves (2009, p. 251 e ss) reputa infundada a restrição que Luhmann dá a questão dos direitos humanos, ao limitar ou enfatizar sua semântica apenas às violações escandalosas e chocantes à dignidade humana ocorridas na sociedade mundial, em situações como "o desaparecimento de pessoas acobertado pelo Estado, as deportações forçadas e as expulsões, a morte, prisão e tortura (juridicamente improcedentes) com o conhecimento e a proteção de órgãos do Estado" (LUHMANN, 2005a, p. 656). Entende Luhmann (2005a, p. 657) que é precisamente aí, onde o Estado de Direito não está garantido e onde os Estados apresentam-se incapazes ou relutantes de agir com os meios disponíveis a este Estado de Direito, que as violações aos direitos humanos poderiam ter curso.

Conforme destacado por Neves (2009, p. 251 e ss), tal limitação a eventos escandalosos e evidentes, como torturas e genocídios, deixa de tomar em consideração, contudo, o fato de que a dignidade humana (ou a face dos direitos humanos enquanto inclusão jurídica generalizada) também é sistematicamente violada pela exclusão social (absoluta) de vários grupos humanos, que não detêm condições mínimas de sobrevivência na sociedade

\footnotetext{
${ }^{101}$ Luhmann está, evidentemente, no caso, analisando a expansão sistêmica desenfreada à luz da atuação do subsistema político da sociedade. Sua observação, contudo, é válida para os demais subsistemas sociais, que também atuam "cegamente" à luz de sua própria racionalidade e tendem a minimizar, desprezar ou a não levar em consideração outras diferenças existentes na sociedade. Na sociedade moderna, marcada pela existência de ordens diferenciadas de comunicação, nenhuma distinção escolhida ou diferença levada a efeito, contudo, pode reclamar validade última, capaz de julgar as demais. Por outro lado, não há nada que escape de uma distinção ou assinalamento. Tudo pode ser distinguido ou assinalado (LUHMANN, 2007, p. 867).
} 
mundial. A diferença entre um e outro aspecto estaria, segundo Neves, no fato de que os direitos humanos em sentido estrito referidos por Luhmann - que proíbem medidas e ações violentas, contra indivíduos ou grupos -, já contariam com um viés positivo ou forte de institucionalização, positivação e implementação processual em escala mundial, enquanto os direitos sociais e mesmo os chamados direitos de terceira geração contariam com um viés fraco ou frágil relativamente à institucionalização, positivação e implementação em âmbito mundial.

Assim sendo, Neves propõe que os direitos humanos sejam entendidos como “expectativas normativas de inclusão jurídica de toda e qualquer pessoa na sociedade (mundial) e, portanto, de acesso universal ao direito enquanto subsistema social" (NEVES, 2009, p. 252-253), definição esta que, conforma o próprio autor (e na esteira do que Luhmann já havia considerado com relação aos direitos fundamentais), não impede nem afasta a compreensão dos direitos humanos também como reação ao perigo da desdiferenciação, na busca pela manutenção de uma ordem diferenciada de comunicações.

Dessa maneira, tanto os direitos humanos quanto os direitos fundamentais dizem respeito à inclusão da pessoa e à diferenciação da sociedade. Os conteúdos praticamente coincidem. A diferença reside no âmbito de suas pretensões de validade. Os direitos fundamentais valem dentro de uma ordem constitucional estatalmente determinada. Os direitos humanos pretendem valer para o sistema jurídico mundial de níveis múltiplos, ou seja, para qualquer ordem jurídica existente na sociedade mundial (não apenas para a ordem jurídica internacional). É claro que existem utilizações práticas dessas expressões de maneira diversa: "Direitos (ou liberdades) fundamentais" usados em tratados ou convenções supranacionais ou internacionais. "Direitos humanos" empregados para o catálogo dos direitos positivados nas Constituições estatais. Mas, do ponto de vista teórico, as definições e diferenças apresentadas servem ao nosso argumento e encontram respaldo na prática jurídica dominante (NEVES, 2009, p. 253-254).

Considerando a realidade de uma fragmentação da sociedade mundial em vários subsistemas sociais autônomos, que atuariam (para além dos limites jurídico-territoriais dos Estados-nação), segundo tendências de reforço e expansão de suas racionalidades parciais próprias, as quais avançariam sobre os respectivos ambientes externos sem limitações imanentes, e considerando que a própria dinâmica de atuação funcionalmente diferenciada dos sistemas sociais produziria simultaneamente inclusão e exclusão de grupos populacionais 
inteiros, Teubner (2012, p. 124-149) trabalha com outra distinção entre direitos humanos e direitos fundamentais.

Segundo ele, os direitos fundamentais possuiriam efeitos inclusivos e também excludentes. Pelo lado da inclusão, os direitos fundamentais atuariam como direitos de participação e de não-discriminação, não somente na política, mas nas diferentes áreas da sociedade como um todo. Eles funcionariam, portanto, como contrainstituições voltadas a garantir a inclusão da população inteira nos (sub)sistemas funcionais sociais. Na política, isso se concretizaria, por exemplo, em direitos políticos, como o direito de voto. No meio comunicativo da internet, isso se concretizaria, por exemplo, na manutenção da neutralidade da rede (TEUBNER, 2012, p. 137-138) e, poder-se-ia acrescentar, num direito de inclusão digital, ou seja, de ter-se efetivamente a possibilidade de fazer uso das mídias digitais.

Pelo lado da exclusão, os direitos fundamentais reagiriam à expansão desenfreada e à tendência totalizante dos subsistemas sociais e de suas respectivas racionalidades (derivadas de sua autonomização e diferenciação funcional), em face de outros subsistemas sociais (e suas racionalidades), das pessoas e dos seres humanos de carne e osso. Eles procurariam garantir, assim, a existência de áreas ou esferas de comunicação autônomas, destinadas, seja a outros subsistemas, processos ou instituições sociais, seja para as pessoas enquanto constructos sociais. Da mesma forma, eles estariam voltados à proteção da integridade da mente e do corpo dos seres humanos de carne e osso, evitando que sobre ela recaia a instrumentalização própria de uma determinada racionalidade social (TEUBNER, 2012, p. 136-142). É, aliás, segundo Teubner, precisamente neste aspecto de proteção à integridade individual de corpo e mente, colocada em risco "por uma multiplicidade de processos comunicativos anônimos, autônomos e hoje globalizados”, que a questão dos direitos humanos, em sentido estrito, deve ser encarada (TEUBNER, 2012, p. 144, tradução nossa).

Nesse cenário, a questão dos direitos fundamentais deve ser vista, segundo Teubner, como uma equação em que, de um lado, figura uma matriz comunicativa autônoma (instituições, discursos, sistemas) e, de outro, não um indivíduo em si, considerado de forma compacta e unitária, mas duas dimensões de direitos fundamentais e uma dimensão de direitos humanos, da seguinte forma: 
- direitos institucionais (institutional rights) que protegem a autonomia de processos sociais contra sua subjugação pelas tendências totalizantes da matriz comunicativa. Protegendo, por exemplo, a integridade da arte, da família ou da religião contra tendências totalitárias da ciência, dos media ou da economia, tais direitos fundamentais vigoram como "regras de conflitos jurídicos" entre racionalidades parciais na sociedade.

- direitos pessoais (personal rights) que protegem os espaços autônomos de comunicação dentro da sociedade, atribuídos não a instituições, mas aos artefatos sociais chamados "pessoas".

- direitos humanos (human rights) como limites negativos para a comunicação social, na qual a integridade do corpo e da mente dos indivíduos é colocada em perigo por uma matriz comunicativa que ultrapassa limites (TEUBNER, 2012, p. 145 , grifos do original, tradução nossa).

O encaixe de um direito específico numa dessas categorias não deve excluir a possibilidade de interseções ou de sobreposições com outras categorias, embora haja direitos voltados mais a uma categoria do que à outra (como a liberdade de arte e de propriedade, em relação à dimensão institucional; a liberdade de expressão, em relação à dimensão pessoal; e a liberdade de consciência, em relação à dimensão humana) (TEUBNER, 2012, p. 145).

Neves (2009, p. 254-255) critica parcialmente as dimensões qualitativamente distinguidas por Teubner, no ponto em que ele separa entre direitos humanos de exclusão do homem da sociedade (que lhe garantiria integridade físico-psíquica) e direitos fundamentais pessoais - que garantiriam a inclusão da pessoa. Para Neves, ambos os aspectos (exclusão do homem e inclusão da pessoa) consubstanciam as duas faces de uma mesma moeda, sendo a inclusão como pessoa justamente o que possibilita o respeito a integridade de corpos e mentes. Significa isso que, uma vez incluídas as pessoas, os homens são tidos não como meros corpos e mentes, mas tomados como dignos de personalidade e de, assim, terem voz e vez nos processos de comunicação.

Como forma de dois lados, a pessoa constitui um acoplamento estrutural entre homem e sociedade, servindo para enfrentar o perigo tanto de que a integridade de seu substrato biopsíquico seja violada ou destruída pela expansão da sociedade quanto de que, ao contrário, esta seja destruída e desintegrada pela falta de limites dos desejos e impulsos humanos (NEVES, 2009, p. 255). 
O posicionamento de Neves, que não vê uma diferença qualitativa significativa entre direitos humanos e direitos fundamentais, já que ambos estariam dirigidos à inclusão da pessoa e à diferenciação da sociedade, aliada à sua perspectiva de considerar a inclusão da pessoa enquanto dobradiça que articula tanto a proteção das expectativas e interesses comunicativos (da pessoa para com a sociedade e da sociedade para com as pessoas), quanto o resguardo da integridade biopsíquica (viabilizada pela consideração do homem enquanto dotado de uma personalidade que lhe permite a expressão comunicativa), permitem concluir que o direito ao esquecimento, em sua formulação atualmente emergente, afigura-se como um discurso que procura, seja com pretensões de validade numa ordem constitucional estatalmente determinada, seja em âmbito mundial (ou, por outras palavras, seja como direito fundamental, seja como direito humano), reagir à racionalidade própria do sistema dos meios de comunicação de massa (ou à sua expansão), garantindo às pessoas o espaço comunicativo necessário para deduzir suas pretensões, com vistas à proteção de sua dignidade, de sua personalidade e de seu substrato biopsíquico.

Isso parece bem claro e paradigmaticamente identificado nos principais casos concretos estudados neste trabalho. Tanto em face da mídia televisiva, quanto em face de motores de busca da internet, verificou-se a mobilização do direito ao esquecimento como forma de reagir e de impor limites (com os consectários legais daí decorrentes) a uma racionalidade que, catalisada por avanços tecnológicos, está continuamente produzindo informações a partir de informações ou novidades a partir da reatualização de verdades já há muito abandonadas e esquecidas, sem a menor preocupação com a integridade das pessoas referidas ou retratadas - a ponto de causar-lhes sofrimentos biopsíquicos e estigmas sociais.

De toda forma, ao tempo em que se garante à pessoa o direito de voz e vez para não ser instrumentalizada pelos meios de massa e de questionar o uso que é feito das informações que lhe dizem respeito, garante-se, na ordem diferenciada de comunicações existente e que se procura manter, que expectativas e pretensões distintas e também contrárias sejam aduzidas, à luz de outros tipos de direitos fundamentais ou humanos, colidentes com o direito ao esquecimento, como a liberdade de informação. Nesse sentido, e considerando o âmbito mundial, os direitos concretamente envolvidos (esquecimento, informação e outros correlatos, os quais se incluem nos direitos humanos em geral) relacionam-se "com a emergência de um dissenso estrutural, concernente não apenas à pluralidade de esferas de comunicação com pretensão de autonomia (complexidade sistêmica), mas também à 
heterogeneidade de expectativas, interesses e valores de pessoas e grupos" (NEVES, 2009, p. 255). Daí que Neves vem a definir os direitos humanos como "expectativas normativas de inclusão jurídica generalizada nas condições de dissenso estrutural da sociedade mundial" (NEVES, 2009, p. 255). 


\section{CONCLUSÃO}

A ideia de esquecimento no direito e na sociedade não é nova, havendo de longa data institutos e instrumentos voltados à sua tipificação e regulação.

O surgimento de um discurso amplo, densificado num direito fundamental ou humano ao esquecimento, parece fundado, contudo, num contexto de redução de custos e aumento exponencial da capacidade da sociedade - mormente dos meios de comunicação de massa - de armazenamento, recuperação e difusão de informações e dados, sobretudo pessoais. Surgido na esteira do direito à privacidade, mas dotado de elementos que lhe dão viés de autonomia, o direito ao esquecimento localiza-se num contexto social de ampla memória (digital), facilmente acessível. Nesse sentido, ele procura municiar as pessoas de um discurso de reação à expansão dos meios de comunicação de massa, impondo limites à sua atuação. Trata-se, portanto, de um direito que emerge, em princípio, como garantia de que as pessoas não sejam instrumentalizadas pela racionalidade própria das mídias de massa.

A proteção das pessoas e de sua integridade biopsíquica densifica-se com a possibilidade de questionamento quanto ao uso ou reuso que é feito de informações passadas (verdadeiras) que lhes digam respeito, mediante postulações que poderão variar de acordo com a situação concreta. Não se trata de censura, nem de apagamento da história. A imprensa mantém ampla liberdade de atuação na realização de seu mister. Os historiadores, cientistas e estatísticos têm seus ofícios resguardados, com os métodos, critérios e responsabilidades que lhes cabem. Doutro lado, considerando-se a desindexação com base no nome das pessoas, não se impede que a informação (e consequentemente a pessoa) continue a ser localizada na internet com base em outros critérios de pesquisa. De toda sorte, em função do papel que desempenham na sociedade, pessoas públicas, em princípio, não são alcançadas pelo direito ao esquecimento. Trata-se, na verdade, assim, não de trocar a liberdade de informação por um esquecimento, mas de não deixar que esta liberdade de informação anule espaços comunicativos destinados às pessoas e à sua integridade biopsíquica. Com isso, busca-se manter o dissenso estrutural que perfaz a sociedade moderna, mormente no tocante às diferenças existentes entre pessoas e grupos com relação a expectativas, interesses e valores. 
A configuração do direito ao esquecimento não está consolidada. Há muita discussão acerca de seus contornos e dos critérios que poderiam distingui-lo com exatidão e torná-lo adequadamente executável. Se ele prevalecerá, que contornos adquirirá ou que uso dele será feito e em que contextos, só se pode especular em trabalhos de futurologia. Longe de prever o futuro, contudo, o presente trabalho buscou jogar luzes sobre o fenômeno, a partir de casos concretos que lhe são basilares, situando-o em seu contexto de emergência vis-à-vis a atuação dos meios de comunicação de massa e as novas tecnologias, com o intuito de contribuir para o aprofundamento de um debate que, desenrolando-se sobre problemas concretos importantes envolvendo as pessoas e seus direitos mais básicos, não pode ser superficializado ou estigmatizado. 


\section{REFERÊNCIAS}

BORGES, Jorge Luis. Funes, o memorioso. In: Ficções (1944). São Paulo: Companhia das Letras, 2007, p. 99-108.

BRASIL. Lei $\mathbf{n}^{\mathbf{0}}$ 8.159, de 8 de janeiro de 1991. Dispõe sobre a política nacional de arquivos públicos e privados e dá outras providências. Disponível em: $<$ http://www.planalto.gov.br/ccivil_03/Leis/L8159.htm>. Acesso em: 11 fev. 2016.

BRASIL. Lei $\mathbf{n}^{0}$ 11.111, de 5 de maio de 2005. Regulamenta a parte final do disposto no inciso XXXIII do caput do art. $5^{\circ}$ da Constituição Federal e dá outras providências. Disponível em: $\quad<$ http://www.planalto.gov.br/ccivil_03/_Ato20042006/2005/Lei/L11111.htm>. Acesso em: 11 fev. 2016.

BRASIL. Lei $n^{0}$ 12.527, de 18 de novembro de 2011. Regula o acesso a informações previsto no inciso XXXIII do art. $5^{\circ}$, no inciso II do $\S 3^{\circ}$ do art. 37 e no $\S 2^{\circ}$ do art. 216 da Constituição Federal; altera a Lei $n^{\circ}$ 8.112, de 11 de dezembro de 1990; revoga a Lei $\mathrm{n}^{\circ}$ 11.111, de 5 de maio de 2005, e dispositivos da Lei $\mathrm{n}^{\circ}$ 8.159, de 8 de janeiro de 1991; e dá outras providências. Disponível em: <http:/www.planalto.gov.br/ccivil_03/_Ato20112014/2011/Lei/L12527.htm>. Acesso em: 11 fev. 2016.

BRASIL. Lei $\mathbf{n}^{\mathbf{0}}$ 12.965, de 23 de abril de 2014. Estabelece princípios, garantias, direitos e deveres para o uso da Internet no Brasil. Disponível em: $<$ http://www.planalto.gov.br/CCIVIL_03/_Ato2011-2014/2014/Lei/L12965.htm>. Acesso em: 11 fev. 2016.

BRASIL. Supremo Tribunal Federal. Ação direta de inconstitucionalidade $\mathbf{n}^{0}$ 4815/DF, Tribunal Pleno, Relatora: Ministra Cármen Lúcia, julgado em 10 jun. 2015. Processo eletrônico DJe-018, divulg. em 29 jan. 2016, public. em 01 fev. 2016. Disponível em: $<$ http://redir.stf.jus.br/paginadorpub/paginador.jsp?docTP=TP\&docID=10162709>. Acesso em: 15 fev. 2016.

BUCAR, Daniel. Controle temporal de dados: o direito ao esquecimento. Revista Civilistica.com. Rio de Janeiro, a. 2, n. 3, jul.-set. 2013. Disponível em: 
$<$ http://civilistica.com/controle-temporal-de-dados-o-direito-ao-esquecimento/>. Acesso em: 04 fev. 2016.

BURGOS, Pedro. Google: me esquece! Galileu, São Paulo, nº 279, p. 56-65, out. 2014.

CASTELlS, Manuel. O poder da comunicação. São Paulo; Rio de Janeiro: Paz e Terra, 2015.

COSTA, André Brandão Nery. Direito ao esquecimento na internet: a scarlet letter digital. In: SCHREIBER, Anderson (coord.). Direito e mídia. São Paulo: Atlas, 2013, p. 184-206.

DONEDA, Danilo. Da privacidade à proteção de dados pessoais. Rio de Janeiro: Renovar, 2006.

DOTTI, René Ariel. Proteção da vida privada e liberdade de informação: possibilidades e limites. São Paulo: Revista dos Tribunais, 1980.

FLEISCHER, Peter. Foggy thinking about the right to oblivion. Peter Fleischer: Privacy...? [blog], 09 mar. 2011. Disponível em: <http://peterfleischer.blogspot.com.br/2011/03/foggythinking-about-right-to-oblivion.html>. Acesso em: 25 jan. 2016.

FRANÇA rejeita recurso do Google contra o "direito ao esquecimento". G1, 21 set. 2015. Disponível em: <http://g1.globo.com/tecnologia/noticia/2015/09/franca-rejeita-recurso-dogoogle-contra-o-direito-ao-esquecimento.html>. Acesso em: $03 \mathrm{dez} .2015$

GOOGLE. Google transparency report. Disponível em: $<$ https://www.google.com/transparencyreport/?hl=pt-BR>. Acesso em: 01 dez. 2015.

GOOGLE. Por dentro da pesquisa: como a pesquisa funciona. Disponível em: $<$ https://www.google.com/intl/pt-br/insidesearch/howsearchworks/>. Acesso em: 01 mar. 2016.

LEMOS, Ronaldo. Esquecer o direito ao esquecimento. Folha de São Paulo, 25 nov. 2014. Disponível em: <http://www1.folha.uol.com.br/colunas/ronaldolemos/2014/11/1552821esquecer-o-direito-ao-esquecimento.shtml>. Acesso em: 26 jan. 2016.

LIMA, Erik Noleta Kirk Palma. Direito ao esquecimento: discussão europeia e sua repercussão no Brasil. Revista de Informação Legislativa, Brasília, ano 50, n. 199, p. 271283, jul.-set. 2013. 
LUHMANN, Niklas. La realidad de los medios de masas. Rubí, Espanha: Anthropos Editorial; México: Universidad Iberoamericana, 2000.

LUHMANN, Niklas. El derecho de la sociedad. 2. ed. México: Herder/Universidad Iberoamericana, 2005a.

LUHMANN, Niklas, A realidade dos meios de comunicação. São Paulo: Paulus, 2005b.

LUHMANN, Niklas. La sociedad de la sociedad. México: Herder/Universidad Iberoamericana, 2007.

LUHMANN, Niklas. Los derechos fundamentales como institución: aportación a la sociología política. México: Universidad Iberoamericana, 2010.

LUHMANN, Niklas. Introdução à teoria dos sistemas. 3. ed. Petrópolis, RJ: Vozes, 2011.

MARCONDES FILHO, Ciro (org.). Dicionário da comunicação. 2. ed. São Paulo: Paulus, 2009.

MARTINEZ, Pablo Dominguez. Direito ao esquecimento: a proteção da memória individual na sociedade da informação. Rio de Janeiro: Lumen Juris, 2014.

MARTINO, Luís Mauro Sá. Teoria das mídias digitais: linguagens, ambientes, redes. 2. ed. Petrópolis, RJ: Vozes, 2015.

MARTINS, Guilherme Magalhães. O direito ao esquecimento na internet. In: (coord.). Direito privado e internet. São Paulo: Atlas, 2014, p. 03-28.

MAYER-SCHÖNBERGER, Viktor. Delete: the virtue of forgetting in the digital age. Princeton: Princeton University Press, 2009.

MOODY, Glyn. Google ordered to remove links to stories about Google removing links to stories. Ars Technica UK, Londres, 21 ago. 2015. Disponível em: $<$ http://arstechnica.co.uk/tech-policy/2015/08/google-ordered-to-remove-links-to-storiesabout-google-removing-links-to-stories/>. Acesso em: 01 dez. 2015.

NAFARRATE, Javier Torres. In memoriam. In: LUHMANN, Niklas. La realidad de los medios de masas. Rubí (Barcelona): Anthropos Editorial; México: Universidad Iberoamericana, 2000, p. VII-XXIV. 
NEVES, Marcelo. Entre Têmis e Leviatã: uma relação difícil: o Estado Democrático de Direito a partir e além de Luhmann e Habermas. São Paulo: Martins Fontes, 2008.

NEVES, Marcelo. Transconstitucionalismo. São Paulo: Martins Fontes, 2009.

OST, François. O tempo do direito. Lisboa: Instituto Piaget, 2001.

PRICE, Jill; DAVIS, Bart. A mulher que não consegue esquecer: relatos da síndrome de hipermemória. São Paulo: Arx, Saraiva, 2010.

RICOEUR, Paul. A memória, a história, o esquecimento. Campinas, SP: Editora da Unicamp, 2007.

RODRIGUES JUNIOR, Otávio Luiz. Brasil debate direito ao esquecimento desde 1990. Revista Consultor Jurídico, 27 nov. 2013 (2013a). Disponível em: $<$ http://www.conjur.com.br/2013-nov-27/direito-comparado-brasil-debate-direitoesquecimento-1990>. Acesso em: 03 fev. 2016.

RODRIGUES JUNIOR, Otávio Luiz. Direito ao esquecimento, a culpa e os erros humanos. Revista Consultor Jurídico, 11 dez. 2013 (2013b). Disponível em: $<$ http://www.conjur.com.br/2013-dez-11/direito-comparado-direito-esquecimento-culpaerros-humanos>. Acesso em: 03 fev. 2016.

RODRIGUES JUNIOR, Otávio Luiz. Direito ao esquecimento na perspectiva do STJ. Revista Consultor Jurídico, 19 dez. 2013 (2013c). Disponível em: $<$ http://www.conjur.com.br/2013-dez-19/direito-comparado-direito-esquecimentoperspectiva-stj>. Acesso em: 03 fev. 2016.

RODRIGUES JUNIOR, Otávio Luiz. Não há tendências na proteção do direito ao esquecimento. Revista Consultor Jurídico, 25 dez. 2013 (2013d). Disponível em: $<$ http://www.conjur.com.br/2013-dez-25/direito-comparado-nao-tendencias-protecao-direitoesquecimento >. Acesso em: 03 fev. 2016.

ROSEN, Jeffrey. The web means the end of forgetting. The New York Times, Nova Iorque, 21 jul. 2010. Disponível em: <http://www.nytimes.com/2010/07/25/magazine/25privacyt2.html?pagewanted=all\&_r=0>. Acesso em: 29 jan. 2016. 
ROSEN, Jeffrey. The right to be forgotten. Stanford Law Review Online, v. 64, p. 88-92, 13 fev. 2012.

SANKIEVICZ, Alexandre. Direito ao esquecimento e sobre fatos e circunstâncias dos trópicos que devemos especialmente ponderar. Cadernos Aslegis, n. 48, p. 87-116, jan.-abr. 2013. Brasília: Aslegis, 2015.

SARLET, Ingo Wolfgang. Do caso Lebach ao caso Google vs. Agência Espanhola de Proteção de Dados. Revista Consultor Jurídico, 05 jun. 2015. Disponível em: $<$ http://www.conjur.com.br/2015-jun-05/direitos-fundamentais-lebach-google-vs-agenciaespanhola-protecao-dados-mario-gonzalez>. Acesso em: 03 fev. 2016.

SCHREIBER, Anderson. Direitos da personalidade. 3. ed. São Paulo: Atlas, 2014.

TEUBNER, Gunther. Constitutional fragments: societal constitutionalism and globalization. Oxford, Inglaterra: Oxford University Press, 2012.

TIPPMAN, Sylvia; POWLES, Julia. Google accidentally reveals data on "right to be forgotten" requests. The Guardian, 14 jul. 2015. Disponível em: $<$ http://www.theguardian.com/technology/2015/jul/14/google-accidentally-reveals-right-tobe-forgotten-requests>. Acesso em: 15 fev. 2016.

TOOBIN, Jeffrey. The solace of oblivion. Revista The New Yorker, Nova Iorque, p. 26-32, 29 set. 2014.

VILICIC, Filipe; ALLEGRETTI, Fernanda. O direito de ser esquecido. Revista Veja, São Paulo, no 32, p. 84-85, 16 jul. 2014.

WARREN, Samuel; BRANDEIS, Louis. The right to privacy. Harvard Law Review, v. 4, n. 5, p. 193-220, 15 dez. 1890.

WRIGHT, R. George. The right to be forgotten: issuing a voluntary recall. Drexel Law Review, v. 7, p. 401-425, 2015. 


\title{
LISTA DE CASOS JUDICIAIS RELATADOS NO CAPÍTULO 1
}

\author{
Alemanha \\ 1. Tribunal Constitucional Federal:
}

1.1 BverfGE 35, 202 - LEBACH. Excertos disponíveis em: MARTINS, Leonardo (org). Cinquenta anos de jurisprudência do Tribunal Constitucional Federal Alemão. Montevidéu: Konrad-Adenauer-Stiftung, 2005, p. 486-493.

\section{Brasil}

1. Superior Tribunal de Justiça (decisões disponíveis para busca no site oficial do STJ: http://www.stj.jus.br/SCON/):

1.1 Recurso Especial n ${ }^{\mathrm{o}}$ 1316921/RJ, Rel. Ministra Nancy Andrighi, $3^{\mathrm{a}}$ Turma, julgado em 26/06/2012, DJe 29/06/2012;

1.2 Recurso Especial n ${ }^{\circ}$ 1334097/RJ, Rel. Ministro Luis Felipe Salomão, 4 ${ }^{\text {a }}$ Turma, julgado em 28/05/2013, DJe 10/09/2013;

1.3 Recurso Especial n ${ }^{\circ}$ 1335153/RJ, Rel. Ministro Luis Felipe Salomão, $4^{\text {a }}$ Turma, julgado em 28/05/2013, DJe 10/09/2013;

1.4 Reclamação no 5.072/AC, Rel. Ministro Marco Buzzi, Rel. para Acórdão Ministra Nancy Andrighi, 2a Seção, julgado em 11/12/2013, DJe 04/06/2014.

1.5 Reclamação $n^{\circ}$ 18.685/ES, Rel. Ricardo Villas Bôas Cueva, decisão monocrática de 05/08/2014, DJe 22/08/2014.

\section{Canadá}

1. Corte de Apelação da Colúmbia Britânica:

1.1 Equustek Solutions Inc. v. Google Inc., 2014 BCCA 295 (CanLII), julgado em 23/07/2014.

Disponível

em:

$<$ http://www.canlii.org/en/bc/bcca/doc/2014/2014bcca295/2014bcca295.html>. Acesso em: $01^{\circ}$ dez. 2015. 
1.2 Equustek Solutions Inc. v. Google Inc., 2015 BCCA 265 (CanLII), julgado em 11/06/2015. Disponível em: $<$ http://www.canlii.org/en/bc/bcca/doc/2015/2015bcca265/2015bcca265.html>. Acesso em $01^{\circ}$ dez. 2015.

2. Suprema Corte da Colúmbia Britânica

2.1 Equustek Solutions Inc. v. Jack, 2014 BCSC 1063 (Can LII), julgado em 13/06/2014. Disponível em: $<$ http://www.canlii.org/en/bc/bcsc/doc/2014/2014bcsc1063/2014bcsc1063.html\#>. Acesso em: $01^{\circ}$ dez. 2015.

\section{União Europeia}

1. Tribunal de Justiça da União Europeia:

1.1 Acórdão no processo $n^{\circ}$ C-131/12, Grande Seção, julgado em 13/05/2014. Disponível em português em: $<$ http://curia.europa.eu/juris/liste.jsf?pro $=\&$ nat $=$ or $\&$ oqp $=\&$ dates $=\& l g=\&$ language $=$ pt\&jur $=C$ $\% 2 \mathrm{CT} \% 2 \mathrm{CF} \& \mathrm{cit}=$ none $\% 252 \mathrm{CC} \% 252 \mathrm{CCJ} \% 252 \mathrm{CR} \% 252 \mathrm{C} 2008 \mathrm{E} \% 252 \mathrm{C} \% 252 \mathrm{C} \% 252 \mathrm{C} \% 252$ $\mathrm{C} \% 252 \mathrm{C} \% 252 \mathrm{C} \% 252 \mathrm{C} \% 252 \mathrm{C} \% 252 \mathrm{C} \% 252 \mathrm{Ctrue} \% 252 \mathrm{Cfalse} \% 252 \mathrm{Cfalse} \&$ num $=\mathrm{c}-$ $131 \% 252 \mathrm{~F} 12 \& \mathrm{td}=\% 3 \mathrm{BALL} \& \mathrm{pcs}=$ Oor\&avg $=\&$ page $=1 \&$ mat $=$ or $\&$ je $=\&$ for $=\& \mathrm{cid}=137000>$. Acesso em 28 nov. 2015. 
ANEXO - LEI No 12.965, DE 23 DE ABRIL DE 2014 (MARCO CIVIL DA INTERNET)

Presidência da República

Casa Civil

Subchefia para Assuntos Jurídicos

\section{LEI No 12.965, DE 23 DE ABRIL DE 2014}

Estabelece princípios, garantias, direitos

e deveres para o uso da Internet no Brasil.

A PRESIDENTA DA REPÚBLICA Faço saber que o Congresso Nacional decreta e eu sanciono a seguinte Lei:

\section{CAPÍTULO I DISPOSIÇÕES PRELIMINARES}

Art. $1^{\circ}$ Esta Lei estabelece princípios, garantias, direitos e deveres para o uso da internet no Brasil e determina as diretrizes para atuação da União, dos Estados, do Distrito Federal e dos Municípios em relação à matéria.

Art. $2^{\circ}$ A disciplina do uso da internet no Brasil tem como fundamento o respeito à liberdade de expressão, bem como:

I - o reconhecimento da escala mundial da rede;

II - os direitos humanos, o desenvolvimento da personalidade e o exercício da cidadania em meios digitais;

III - a pluralidade e a diversidade;

IV - a abertura e a colaboração;

V - a livre iniciativa, a livre concorrência e a defesa do consumidor; e 
VI - a finalidade social da rede.

Art. $3^{\circ}$ A disciplina do uso da internet no Brasil tem os seguintes princípios:

I - garantia da liberdade de expressão, comunicação e manifestação de pensamento, nos termos da Constituição Federal;

II - proteção da privacidade;

III - proteção dos dados pessoais, na forma da lei;

IV - preservação e garantia da neutralidade de rede;

V - preservação da estabilidade, segurança e funcionalidade da rede, por meio de medidas técnicas compatíveis com os padrões internacionais e pelo estímulo ao uso de boas práticas;

VI - responsabilização dos agentes de acordo com suas atividades, nos termos da lei;

VII - preservação da natureza participativa da rede;

VIII - liberdade dos modelos de negócios promovidos na internet, desde que não conflitem com os demais princípios estabelecidos nesta Lei.

Parágrafo único. Os princípios expressos nesta Lei não excluem outros previstos no ordenamento jurídico pátrio relacionados à matéria ou nos tratados internacionais em que a República Federativa do Brasil seja parte.

Art. $4^{\circ}$ A disciplina do uso da internet no Brasil tem por objetivo a promoção:

I - do direito de acesso à internet a todos;

II - do acesso à informação, ao conhecimento e à participação na vida cultural e na condução dos assuntos públicos;

III - da inovação e do fomento à ampla difusão de novas tecnologias e modelos de uso e acesso; e 
IV - da adesão a padrões tecnológicos abertos que permitam a comunicação, a acessibilidade e a interoperabilidade entre aplicações e bases de dados.

Art. $5^{\circ}$ Para os efeitos desta Lei, considera-se:

I - internet: o sistema constituído do conjunto de protocolos lógicos, estruturado em escala mundial para uso público e irrestrito, com a finalidade de possibilitar a comunicação de dados entre terminais por meio de diferentes redes;

II - terminal: o computador ou qualquer dispositivo que se conecte à internet;

III - endereço de protocolo de internet (endereço IP): o código atribuído a um terminal de uma rede para permitir sua identificação, definido segundo parâmetros internacionais;

IV - administrador de sistema autônomo: a pessoa física ou jurídica que administra blocos de endereço IP específicos e o respectivo sistema autônomo de roteamento, devidamente cadastrada no ente nacional responsável pelo registro e distribuição de endereços IP geograficamente referentes ao País;

V - conexão à internet: a habilitação de um terminal para envio e recebimento de pacotes de dados pela internet, mediante a atribuição ou autenticação de um endereço IP;

VI - registro de conexão: o conjunto de informações referentes à data e hora de início e término de uma conexão à internet, sua duração e o endereço IP utilizado pelo terminal para o envio e recebimento de pacotes de dados;

VII - aplicações de internet: o conjunto de funcionalidades que podem ser acessadas por meio de um terminal conectado à internet; e

VIII - registros de acesso a aplicações de internet: o conjunto de informações referentes à data e hora de uso de uma determinada aplicação de internet a partir de um determinado endereço IP.

Art. $6^{\circ} \mathrm{Na}$ interpretação desta Lei serão levados em conta, além dos fundamentos, princípios e objetivos previstos, a natureza da internet, seus usos e costumes particulares e sua importância para a promoção do desenvolvimento humano, econômico, social e cultural. 


\section{CAPÍTULO II \\ DOS DIREITOS E GARANTIAS DOS USUÁRIOS}

Art. $7^{\circ} \mathrm{O}$ acesso à internet é essencial ao exercício da cidadania, e ao usuário são assegurados os seguintes direitos:

I - inviolabilidade da intimidade e da vida privada, sua proteção e indenização pelo dano material ou moral decorrente de sua violação;

II - inviolabilidade e sigilo do fluxo de suas comunicações pela internet, salvo por ordem judicial, na forma da lei;

III - inviolabilidade e sigilo de suas comunicações privadas armazenadas, salvo por ordem judicial;

IV - não suspensão da conexão à internet, salvo por débito diretamente decorrente de sua utilização;

V - manutenção da qualidade contratada da conexão à internet;

VI - informações claras e completas constantes dos contratos de prestação de serviços, com detalhamento sobre o regime de proteção aos registros de conexão e aos registros de acesso a aplicações de internet, bem como sobre práticas de gerenciamento da rede que possam afetar sua qualidade;

VII - não fornecimento a terceiros de seus dados pessoais, inclusive registros de conexão, e de acesso a aplicações de internet, salvo mediante consentimento livre, expresso e informado ou nas hipóteses previstas em lei;

VIII - informações claras e completas sobre coleta, uso, armazenamento, tratamento e proteção de seus dados pessoais, que somente poderão ser utilizados para finalidades que:

a) justifiquem sua coleta;

b) não sejam vedadas pela legislação; e 
c) estejam especificadas nos contratos de prestação de serviços ou em termos de uso de aplicações de internet;

IX - consentimento expresso sobre coleta, uso, armazenamento e tratamento de dados pessoais, que deverá ocorrer de forma destacada das demais cláusulas contratuais;

$X$ - exclusão definitiva dos dados pessoais que tiver fornecido a determinada aplicação de internet, a seu requerimento, ao término da relação entre as partes, ressalvadas as hipóteses de guarda obrigatória de registros previstas nesta Lei;

XI - publicidade e clareza de eventuais políticas de uso dos provedores de conexão à internet e de aplicações de internet;

XII - acessibilidade, consideradas as características físico-motoras, perceptivas, sensoriais, intelectuais e mentais do usuário, nos termos da lei; e

XIII - aplicação das normas de proteção e defesa do consumidor nas relações de consumo realizadas na internet.

Art. $8^{\circ}$ A garantia do direito à privacidade e à liberdade de expressão nas comunicações é condição para o pleno exercício do direito de acesso à internet.

Parágrafo único. São nulas de pleno direito as cláusulas contratuais que violem o disposto no caput, tais como aquelas que:

I - impliquem ofensa à inviolabilidade e ao sigilo das comunicações privadas, pela internet; ou II - em contrato de adesão, não ofereçam como alternativa ao contratante a adoção do foro brasileiro para solução de controvérsias decorrentes de serviços prestados no Brasil.

\section{CAPÍTULO III}

DA PROVISÃO DE CONEXÃO E DE APLICAÇÕES DE INTERNET

\section{Seção I}

Da Neutralidade de Rede 
Art. $9^{\circ} \mathrm{O}$ responsável pela transmissão, comutação ou roteamento tem o dever de tratar de forma isonômica quaisquer pacotes de dados, sem distinção por conteúdo, origem e destino, serviço, terminal ou aplicação.

$\S 1^{\circ}$ A discriminação ou degradação do tráfego será regulamentada nos termos das atribuições privativas do Presidente da República previstas no inciso IV do art. 84 da Constituição Federal, para a fiel execução desta Lei, ouvidos o Comitê Gestor da Internet e a Agência Nacional de Telecomunicações, e somente poderá decorrer de:

I - requisitos técnicos indispensáveis à prestação adequada dos serviços e aplicações; e

II - priorização de serviços de emergência.

$\S 2^{\circ} \mathrm{Na}$ hipótese de discriminação ou degradação do tráfego prevista no $\S 1^{\circ}$, o responsável mencionado no caput deve:

I - abster-se de causar dano aos usuários, na forma do art. 927 da Lei $\mathrm{n}^{\mathrm{o}} 10.406$, de 10 de janeiro de 2002 - Código Civil;

II - agir com proporcionalidade, transparência e isonomia;

III - informar previamente de modo transparente, claro e suficientemente descritivo aos seus usuários sobre as práticas de gerenciamento e mitigação de tráfego adotadas, inclusive as relacionadas à segurança da rede; e

IV - oferecer serviços em condições comerciais não discriminatórias e abster-se de praticar condutas anticoncorrenciais.

$\S 3^{\circ} \mathrm{Na}$ provisão de conexão à internet, onerosa ou gratuita, bem como na transmissão, comutação ou roteamento, é vedado bloquear, monitorar, filtrar ou analisar o conteúdo dos pacotes de dados, respeitado o disposto neste artigo.

\section{Seção II}

Da Proteção aos Registros, aos Dados Pessoais e às Comunicações Privadas 
Art. 10. A guarda e a disponibilização dos registros de conexão e de acesso a aplicações de internet de que trata esta Lei, bem como de dados pessoais e do conteúdo de comunicações privadas, devem atender à preservação da intimidade, da vida privada, da honra e da imagem das partes direta ou indiretamente envolvidas.

$\S 1^{\circ} \mathrm{O}$ provedor responsável pela guarda somente será obrigado a disponibilizar os registros mencionados no caput, de forma autônoma ou associados a dados pessoais ou a outras informações que possam contribuir para a identificação do usuário ou do terminal, mediante ordem judicial, na forma do disposto na Seção IV deste Capítulo, respeitado o disposto no art. $7^{\mathbf{o}}$.

$\S 2^{\circ} \mathrm{O}$ conteúdo das comunicações privadas somente poderá ser disponibilizado mediante ordem judicial, nas hipóteses e na forma que a lei estabelecer, respeitado o disposto nos incisos II e III do art. $7^{\circ}$.

$\S 3^{\circ} \mathrm{O}$ disposto no caput não impede o acesso aos dados cadastrais que informem qualificação pessoal, filiação e endereço, na forma da lei, pelas autoridades administrativas que detenham competência legal para a sua requisição.

$\S 4^{\circ}$ As medidas e os procedimentos de segurança e de sigilo devem ser informados pelo responsável pela provisão de serviços de forma clara e atender a padrões definidos em regulamento, respeitado seu direito de confidencialidade quanto a segredos empresariais.

Art. 11. Em qualquer operação de coleta, armazenamento, guarda e tratamento de registros, de dados pessoais ou de comunicações por provedores de conexão e de aplicações de internet em que pelo menos um desses atos ocorra em território nacional, deverão ser obrigatoriamente respeitados a legislação brasileira e os direitos à privacidade, à proteção dos dados pessoais e ao sigilo das comunicações privadas e dos registros.

$\S 1^{\circ} \mathrm{O}$ disposto no caput aplica-se aos dados coletados em território nacional e ao conteúdo das comunicações, desde que pelo menos um dos terminais esteja localizado no Brasil.

$\S 2^{\circ} \mathrm{O}$ disposto no caput aplica-se mesmo que as atividades sejam realizadas por pessoa jurídica sediada no exterior, desde que oferte serviço ao público brasileiro ou pelo menos uma integrante do mesmo grupo econômico possua estabelecimento no Brasil. 
$\S 3^{\circ}$ Os provedores de conexão e de aplicações de internet deverão prestar, na forma da regulamentação, informações que permitam a verificação quanto ao cumprimento da legislação brasileira referente à coleta, à guarda, ao armazenamento ou ao tratamento de dados, bem como quanto ao respeito à privacidade e ao sigilo de comunicações.

$\S 4^{\circ}$ Decreto regulamentará o procedimento para apuração de infrações ao disposto neste artigo.

Art. 12. Sem prejuízo das demais sanções cíveis, criminais ou administrativas, as infrações às normas previstas nos arts. 10 e 11 ficam sujeitas, conforme o caso, às seguintes sanções, aplicadas de forma isolada ou cumulativa:

I - advertência, com indicação de prazo para adoção de medidas corretivas;

II - multa de até $10 \%$ (dez por cento) do faturamento do grupo econômico no Brasil no seu último exercício, excluídos os tributos, considerados a condição econômica do infrator e o princípio da proporcionalidade entre a gravidade da falta e a intensidade da sanção;

III - suspensão temporária das atividades que envolvam os atos previstos no art. 11; ou

IV - proibição de exercício das atividades que envolvam os atos previstos no art. 11.

Parágrafo único. Tratando-se de empresa estrangeira, responde solidariamente pelo pagamento da multa de que trata o caput sua filial, sucursal, escritório ou estabelecimento situado no País.

\section{Subseção I}

\section{Da Guarda de Registros de Conexão}

Art. 13. Na provisão de conexão à internet, cabe ao administrador de sistema autônomo respectivo o dever de manter os registros de conexão, sob sigilo, em ambiente controlado e de segurança, pelo prazo de 1 (um) ano, nos termos do regulamento.

$\S 1^{\circ}$ A responsabilidade pela manutenção dos registros de conexão não poderá ser transferida a terceiros. 
$\S 2^{\circ}$ A autoridade policial ou administrativa ou o Ministério Público poderá requerer cautelarmente que os registros de conexão sejam guardados por prazo superior ao previsto no caput.

$\S 3^{\circ} \mathrm{Na}$ hipótese do $\S 2^{\circ}$, a autoridade requerente terá o prazo de 60 (sessenta) dias, contados a partir do requerimento, para ingressar com o pedido de autorização judicial de acesso aos registros previstos no caput.

$\S 4^{\circ} \mathrm{O}$ provedor responsável pela guarda dos registros deverá manter sigilo em relação ao requerimento previsto no $\S 2^{\circ}$, que perderá sua eficácia caso o pedido de autorização judicial seja indeferido ou não tenha sido protocolado no prazo previsto no $\S 3^{\circ}$.

$\S 5^{\circ}$ Em qualquer hipótese, a disponibilização ao requerente dos registros de que trata este artigo deverá ser precedida de autorização judicial, conforme disposto na Seção IV deste Capítulo.

$\S 6^{\circ} \mathrm{Na}$ aplicação de sanções pelo descumprimento ao disposto neste artigo, serão considerados a natureza e a gravidade da infração, os danos dela resultantes, eventual vantagem auferida pelo infrator, as circunstâncias agravantes, os antecedentes do infrator e a reincidência.

\section{Subseção II}

\section{Da Guarda de Registros de Acesso a Aplicações de Internet na Provisão de Conexão}

Art. 14. Na provisão de conexão, onerosa ou gratuita, é vedado guardar os registros de acesso a aplicações de internet.

\section{Subseção III}

\section{Da Guarda de Registros de Acesso a Aplicações de Internet na Provisão de Aplicações}

Art. 15. O provedor de aplicações de internet constituído na forma de pessoa jurídica e que exerça essa atividade de forma organizada, profissionalmente e com fins econômicos deverá manter os respectivos registros de acesso a aplicações de internet, sob sigilo, em ambiente controlado e de segurança, pelo prazo de 6 (seis) meses, nos termos do regulamento. 
$\S 1^{\circ}$ Ordem judicial poderá obrigar, por tempo certo, os provedores de aplicações de internet que não estão sujeitos ao disposto no caput a guardarem registros de acesso a aplicações de internet, desde que se trate de registros relativos a fatos específicos em período determinado.

$\S 2^{\circ}$ A autoridade policial ou administrativa ou o Ministério Público poderão requerer cautelarmente a qualquer provedor de aplicações de internet que os registros de acesso a aplicações de internet sejam guardados, inclusive por prazo superior ao previsto no caput, observado o disposto nos $\S \S 3^{\circ}$ e $4^{\circ}$ do art. 13.

$\S 3^{\circ}$ Em qualquer hipótese, a disponibilização ao requerente dos registros de que trata este artigo deverá ser precedida de autorização judicial, conforme disposto na Seção IV deste Capítulo.

$\S 4^{\mathrm{o}} \mathrm{Na}$ aplicação de sanções pelo descumprimento ao disposto neste artigo, serão considerados a natureza e a gravidade da infração, os danos dela resultantes, eventual vantagem auferida pelo infrator, as circunstâncias agravantes, os antecedentes do infrator e a reincidência.

Art. 16. Na provisão de aplicações de internet, onerosa ou gratuita, é vedada a guarda:

I - dos registros de acesso a outras aplicações de internet sem que o titular dos dados tenha consentido previamente, respeitado o disposto no art. $7^{\circ}$; ou

II - de dados pessoais que sejam excessivos em relação à finalidade para a qual foi dado consentimento pelo seu titular.

Art. 17. Ressalvadas as hipóteses previstas nesta Lei, a opção por não guardar os registros de acesso a aplicações de internet não implica responsabilidade sobre danos decorrentes do uso desses serviços por terceiros.

\section{Seção III}

\section{Da Responsabilidade por Danos Decorrentes de Conteúdo Gerado por Terceiros}

Art. 18. O provedor de conexão à internet não será responsabilizado civilmente por danos decorrentes de conteúdo gerado por terceiros. 
Art. 19. Com o intuito de assegurar a liberdade de expressão e impedir a censura, o provedor de aplicações de internet somente poderá ser responsabilizado civilmente por danos decorrentes de conteúdo gerado por terceiros se, após ordem judicial específica, não tomar as providências para, no âmbito e nos limites técnicos do seu serviço e dentro do prazo assinalado, tornar indisponível o conteúdo apontado como infringente, ressalvadas as disposições legais em contrário.

$\S 1^{\circ}$ A ordem judicial de que trata o caput deverá conter, sob pena de nulidade, identificação clara e específica do conteúdo apontado como infringente, que permita a localização inequívoca do material.

$\S 2^{\circ}$ A aplicação do disposto neste artigo para infrações a direitos de autor ou a direitos conexos depende de previsão legal específica, que deverá respeitar a liberdade de expressão e demais garantias previstas no art. $5^{\circ}$ da Constituição Federal.

$\S 3^{\circ}$ As causas que versem sobre ressarcimento por danos decorrentes de conteúdos disponibilizados na internet relacionados à honra, à reputação ou a direitos de personalidade, bem como sobre a indisponibilização desses conteúdos por provedores de aplicações de internet, poderão ser apresentadas perante os juizados especiais.

$\S 4^{\circ} \mathrm{O}$ juiz, inclusive no procedimento previsto no $\S 3^{\circ}$, poderá antecipar, total ou parcialmente, os efeitos da tutela pretendida no pedido inicial, existindo prova inequívoca do fato e considerado o interesse da coletividade na disponibilização do conteúdo na internet, desde que presentes os requisitos de verossimilhança da alegação do autor e de fundado receio de dano irreparável ou de difícil reparação.

Art. 20. Sempre que tiver informações de contato do usuário diretamente responsável pelo conteúdo a que se refere o art. 19, caberá ao provedor de aplicações de internet comunicar-lhe os motivos e informações relativos à indisponibilização de conteúdo, com informações que permitam o contraditório e a ampla defesa em juízo, salvo expressa previsão legal ou expressa determinação judicial fundamentada em contrário.

Parágrafo único. Quando solicitado pelo usuário que disponibilizou o conteúdo tornado indisponível, o provedor de aplicações de internet que exerce essa atividade de forma 
organizada, profissionalmente e com fins econômicos substituirá o conteúdo tornado indisponível pela motivação ou pela ordem judicial que deu fundamento à indisponibilização.

Art. 21. O provedor de aplicações de internet que disponibilize conteúdo gerado por terceiros será responsabilizado subsidiariamente pela violação da intimidade decorrente da divulgação, sem autorização de seus participantes, de imagens, de vídeos ou de outros materiais contendo cenas de nudez ou de atos sexuais de caráter privado quando, após o recebimento de notificação pelo participante ou seu representante legal, deixar de promover, de forma diligente, no âmbito e nos limites técnicos do seu serviço, a indisponibilização desse conteúdo.

Parágrafo único. A notificação prevista no caput deverá conter, sob pena de nulidade, elementos que permitam a identificação específica do material apontado como violador da intimidade do participante e a verificação da legitimidade para apresentação do pedido.

\section{Seção IV}

\section{Da Requisição Judicial de Registros}

Art. 22. A parte interessada poderá, com o propósito de formar conjunto probatório em processo judicial cível ou penal, em caráter incidental ou autônomo, requerer ao juiz que ordene ao responsável pela guarda o fornecimento de registros de conexão ou de registros de acesso a aplicações de internet.

Parágrafo único. Sem prejuízo dos demais requisitos legais, o requerimento deverá conter, sob pena de inadmissibilidade:

I - fundados indícios da ocorrência do ilícito;

II - justificativa motivada da utilidade dos registros solicitados para fins de investigação ou instrução probatória; e

III - período ao qual se referem os registros.

Art. 23. Cabe ao juiz tomar as providências necessárias à garantia do sigilo das informações recebidas e à preservação da intimidade, da vida privada, da honra e da imagem do usuário, podendo determinar segredo de justiça, inclusive quanto aos pedidos de guarda de registro. 


\section{CAPÍTULO IV \\ DA ATUAÇÃO DO PODER PÚBLICO}

Art. 24. Constituem diretrizes para a atuação da União, dos Estados, do Distrito Federal e dos Municípios no desenvolvimento da internet no Brasil:

I - estabelecimento de mecanismos de governança multiparticipativa, transparente, colaborativa e democrática, com a participação do governo, do setor empresarial, da sociedade civil e da comunidade acadêmica;

II - promoção da racionalização da gestão, expansão e uso da internet, com participação do Comitê Gestor da internet no Brasil;

III - promoção da racionalização e da interoperabilidade tecnológica dos serviços de governo eletrônico, entre os diferentes Poderes e âmbitos da Federação, para permitir o intercâmbio de informações e a celeridade de procedimentos;

IV - promoção da interoperabilidade entre sistemas e terminais diversos, inclusive entre os diferentes âmbitos federativos e diversos setores da sociedade;

V - adoção preferencial de tecnologias, padrões e formatos abertos e livres;

VI - publicidade e disseminação de dados e informações públicos, de forma aberta e estruturada;

VII - otimização da infraestrutura das redes e estímulo à implantação de centros de armazenamento, gerenciamento e disseminação de dados no País, promovendo a qualidade técnica, a inovação e a difusão das aplicações de internet, sem prejuízo à abertura, à neutralidade e à natureza participativa;

VIII - desenvolvimento de ações e programas de capacitação para uso da internet;

IX - promoção da cultura e da cidadania; e

$X$ - prestação de serviços públicos de atendimento ao cidadão de forma integrada, eficiente, simplificada e por múltiplos canais de acesso, inclusive remotos. 
Art. 25. As aplicações de internet de entes do poder público devem buscar:

I - compatibilidade dos serviços de governo eletrônico com diversos terminais, sistemas operacionais e aplicativos para seu acesso;

II - acessibilidade a todos os interessados, independentemente de suas capacidades físicomotoras, perceptivas, sensoriais, intelectuais, mentais, culturais e sociais, resguardados os aspectos de sigilo e restrições administrativas e legais;

III - compatibilidade tanto com a leitura humana quanto com o tratamento automatizado das informações;

IV - facilidade de uso dos serviços de governo eletrônico; e

V - fortalecimento da participação social nas políticas públicas.

Art. 26. O cumprimento do dever constitucional do Estado na prestação da educação, em todos os níveis de ensino, inclui a capacitação, integrada a outras práticas educacionais, para o uso seguro, consciente e responsável da internet como ferramenta para o exercício da cidadania, a promoção da cultura e o desenvolvimento tecnológico.

Art. 27. As iniciativas públicas de fomento à cultura digital e de promoção da internet como ferramenta social devem:

I - promover a inclusão digital;

II - buscar reduzir as desigualdades, sobretudo entre as diferentes regiões do País, no acesso às tecnologias da informação e comunicação e no seu uso; e

III - fomentar a produção e circulação de conteúdo nacional.

Art. 28. O Estado deve, periodicamente, formular e fomentar estudos, bem como fixar metas, estratégias, planos e cronogramas, referentes ao uso e desenvolvimento da internet no País.

CAPÍTULO V DISPOSIÇÕES FINAIS 
Art. 29. O usuário terá a opção de livre escolha na utilização de programa de computador em seu terminal para exercício do controle parental de conteúdo entendido por ele como impróprio a seus filhos menores, desde que respeitados os princípios desta Lei e da Lei $\mathrm{n}^{\mathrm{o}}$ 8.069, de 13 de julho de 1990 - Estatuto da Criança e do Adolescente.

Parágrafo único. Cabe ao poder público, em conjunto com os provedores de conexão e de aplicações de internet e a sociedade civil, promover a educação e fornecer informações sobre o uso dos programas de computador previstos no caput, bem como para a definição de boas práticas para a inclusão digital de crianças e adolescentes.

Art. 30. A defesa dos interesses e dos direitos estabelecidos nesta Lei poderá ser exercida em juízo, individual ou coletivamente, na forma da lei.

Art. 31. Até a entrada em vigor da lei específica prevista no $\S 2^{\circ}$ do art. 19 , a responsabilidade do provedor de aplicações de internet por danos decorrentes de conteúdo gerado por terceiros, quando se tratar de infração a direitos de autor ou a direitos conexos, continuará a ser disciplinada pela legislação autoral vigente aplicável na data da entrada em vigor desta Lei.

Art. 32. Esta Lei entra em vigor após decorridos 60 (sessenta) dias de sua publicação oficial.

Brasília, 23 de abril de 2014; $193^{\circ}$ da Independência e $126^{\circ}$ da República.

DILMA ROUSSEFF

José Eduardo Cardozo

Miriam Belchior

Paulo Bernardo Silva

Clélio Campolina Diniz

Observação: Este texto não substitui o publicado no Diário Oficial da União de 24 de abril de 2014. 